\title{
Conformational Control in Main Group Phosphazane Anion Receptors and Transporters
}

Alex J. Plajer, ${ }^{*},[a] ~ J i n b o ~ Z h u,{ }^{[b]}$ Patrick Pröhm, , ${ }^{[c]}$ Felix J. Rizzuto, ${ }^{[a]}$ Ulrich F. Keyser, ${ }^{[a]}$ Dominic S. Wright ${ }^{*},[a]$

\section{Synthetic Procedures}

\section{General Experimental Methods}

All experiments involving phosphorus(III) containing species were carried out on a Schlenkline under nitrogen atmosphere or with the aid of a $\mathrm{N}_{2}$-filled glove box (Saffron type $\alpha$ ). Toluene and THF were dried under nitrogen over sodium or sodium/benzophenone, respectively, whereas acetonitrile and $\mathrm{CH}_{2} \mathrm{Cl}_{2}$ was dried over calcium hydride. ${ }^{1} \mathrm{H},{ }^{13} \mathrm{C}\left\{{ }^{1} \mathrm{H}\right\},{ }^{31} \mathrm{P}\left\{{ }^{1} \mathrm{H}\right\} \mathrm{NMR}$ spectra were recorded on a Bruker Avance 400 QNP or Bruker Avance $500 \mathrm{MHz}$ cryo spectrometer. All spectra were recorded with $\mathrm{SiMe}_{4}\left({ }^{1} \mathrm{H}\right), \mathrm{H}_{3} \mathrm{PO}_{4}\left({ }^{31} \mathrm{P}, 85 \%\right.$ in $\left.\mathrm{D}_{2} \mathrm{O}\right)$ as external standards and referenced to the residual solvent signal. All reagents were purchased from commercial sources and used as received without further purification unless stated differently. $\left[\mathrm{P}\left(\mu-\mathrm{N}^{\mathrm{t} B u}\right) \mathrm{Cl}_{2}\right.$ and $\left[\mathrm{Se}=\mathrm{P}\left(\mu-\mathrm{N}^{\mathrm{t} B u}\right) \mathrm{NH}\left(3,5-\mathrm{CF}_{3} \mathrm{C}_{6} \mathrm{H}_{3}\right)\right]_{2}(\mathbf{8})$ were synthesized via the literature procedures. ${ }^{[1,2]}$ Elemental analysis was obtained using a Perkin Elmer 240 Elemental Analyser. 


\section{Synthesis of new compounds}

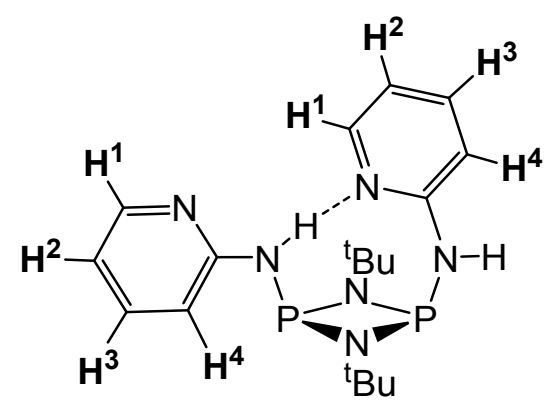

Synthesis of 1: Inside a $\mathrm{N}_{2}$ filled glovebox a Schlenk tube was charged with $\left[\mathrm{P}\left(\mu-\mathrm{N}^{\mathrm{t}} \mathrm{Bu}\right) \mathrm{Cl}\right]_{2}$ $(2.75 \mathrm{~g}, 10 \mathrm{mmol})$ and transferred to a Schlenk line. $20 \mathrm{ml}$ of THF and 2-aminopyridine $(1.88 \mathrm{~g}$, $20 \mathrm{mmol}, 2$ equivalents) in $20 \mathrm{ml}$ THF and $20 \mathrm{ml} \mathrm{Et} 3 \mathrm{~N}$ were added subsequently at room temperature. The resulting mixture was then stirred overnight at $40^{\circ} \mathrm{C}$. Afterwards the solvent was removed in vacuo and the resulting solid mixture was extracted with $80 \mathrm{ml}$ of $\mathrm{n}$-hexane. The solvent was removed in vacuo until the precipitation of a white solid was observed which was gently heated back into solution. Storage of the solution at $-20^{\circ} \mathrm{C}$ led to the formation of colourless crystals which were isolated by filtration and dried in vacuo to yield 1 as a colourless crystalline powder $(1.25 \mathrm{~g}, 3.23 \mathrm{mmol}, 32 \%)$.

${ }^{1} \mathrm{H}$ NMR $\left(25^{\circ} \mathrm{C}, \mathrm{CD}_{3} \mathrm{Cl}, 500 \mathrm{MHz}\right): \delta[\mathrm{ppm}]=8.18\left(\mathrm{~d}, 2 \mathrm{H},{ }^{3} \mathrm{~J}_{\mathrm{HH}}=5.1 \mathrm{~Hz}, \mathrm{H} 1\right), 7.51-7.43(\mathrm{~m}$, $2 \mathrm{H}, \mathrm{H} 3), 6.94\left(\mathrm{~d}, 2 \mathrm{H},{ }^{3} \mathrm{~J}_{\mathrm{HH}}=8.5 \mathrm{~Hz}, \mathrm{H} 4\right), 6.72\left(\mathrm{dd}, 2 \mathrm{H},{ }^{3} \mathrm{~J}_{\mathrm{HH}}=7.1 \mathrm{~Hz},{ }^{3} \mathrm{~J}_{\mathrm{HH}}=5.0 \mathrm{~Hz}, \mathrm{H} 2\right), 6.15$ (bs, $2 \mathrm{H}, \mathrm{NH}), 1.25\left(\mathrm{~s}, 18 \mathrm{H},{ }^{\mathrm{t}} \mathrm{Bu}\right)$

${ }^{31} \mathrm{P}$ NMR (25ํ) $\left.{ }^{\circ} \mathrm{CD}_{3} \mathrm{Cl}, 202 \mathrm{MHz}\right): \delta[\mathrm{ppm}]=106.38$ (s).

Elemental analysis (\%): calcd. for 1: C 55.4, H 7.2, N 21.5; found: C 55.7, H 7.4, H 21.3

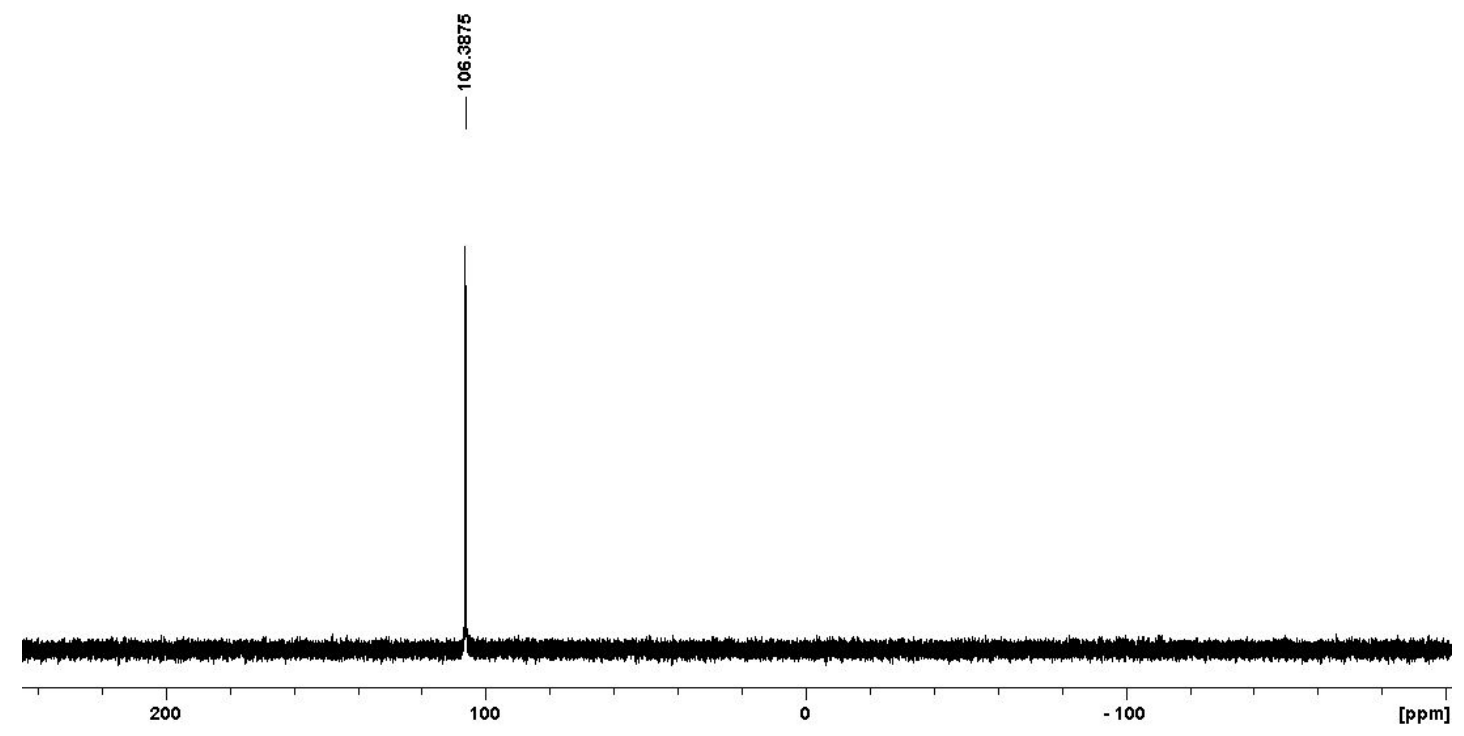

Figure S 1: ${ }^{31} \mathrm{P}$ NMR spectrum $\left(25^{\circ} \mathrm{C}, \mathrm{CD}_{3} \mathrm{Cl}, 202 \mathrm{MHz}\right)$ of 1 


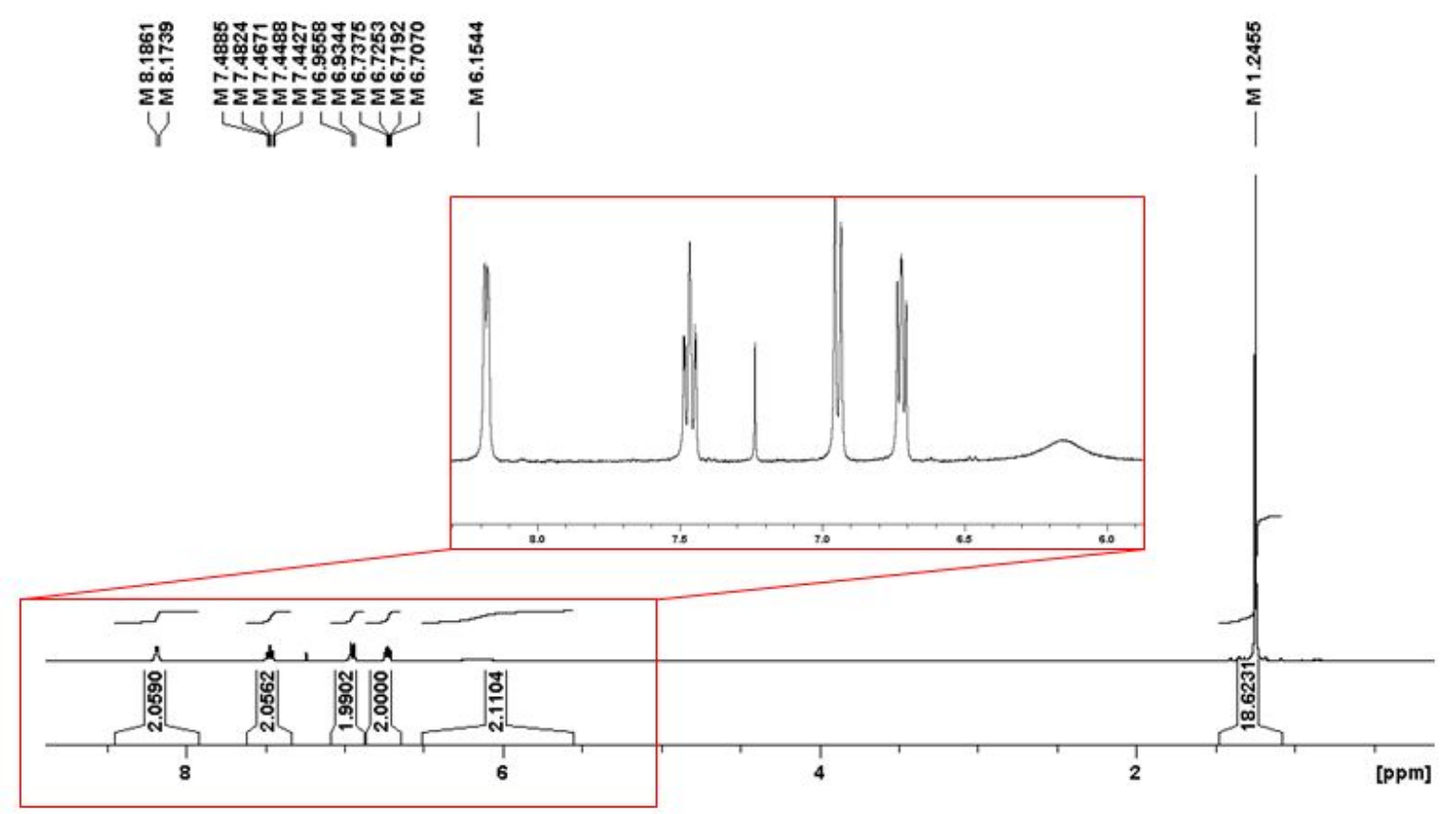

Figure S 2: ${ }^{1} \mathrm{H}$ NMR spectrum $\left(25^{\circ} \mathrm{C}, \mathrm{CD}_{3} \mathrm{Cl}, 500 \mathrm{MHz}\right)$ of 1 


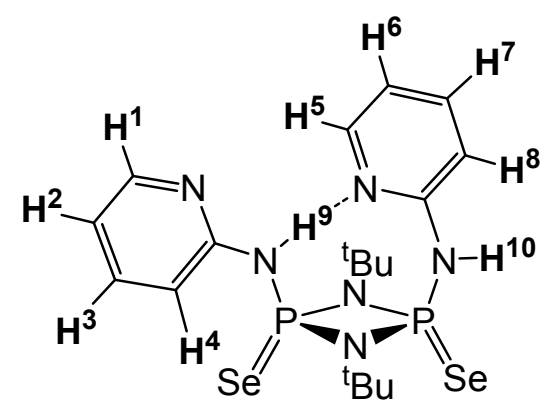

Synthesis of 2: Inside a $\mathrm{N}_{2}$ filled glovebox a Schlenk tube was charged with 2 (200 mg, $0.52 \mathrm{mmol}$ ) and selenium (156mg, $2 \mathrm{mmol}$ ) and transferred to a Schlenk line. $20 \mathrm{ml}$ of THF were added and the mixture was stirred at room temperature. The progress of the oxidation was monitored via in situ ${ }^{31} \mathrm{P}$ NMR spectroscopy. After completion, excess selenium was removed via filtration and the solvent was removed in vacuo yielding 2 as an air stable white solid ( 275mg, 96\%).

${ }^{1} \mathbf{H}$ NMR $\left(25^{\circ} \mathbf{C}, \mathbf{d}_{6}\right.$-DMSO, 500MHz): $\delta[p p m]=10.68\left(\mathrm{~d},{ }^{4} \mathrm{~J}_{\mathrm{HH}}=7.0 \mathrm{~Hz}, 1 \mathrm{H}, \mathrm{H} 9\right), 9.46\left(\mathrm{~d},{ }^{3} \mathrm{~J}_{\mathrm{PH}}\right.$ $=18 \mathrm{~Hz}, 1 \mathrm{H}, \mathrm{H} 10), 8.72\left(\mathrm{~d}, \mathrm{~J}_{\mathrm{HH}}=3.9 \mathrm{~Hz}, 1 \mathrm{H}, \mathrm{H1}\right), 8.32\left(\mathrm{~d}, \mathrm{~J}_{\mathrm{HH}}=3.9 \mathrm{~Hz}, 1 \mathrm{H}, \mathrm{H} 5\right), 8.14\left(\mathrm{~d}, \mathrm{~J}_{\mathrm{HH}}=\right.$ $8.5 \mathrm{~Hz}, 1 \mathrm{H}, \mathrm{H} 8), 7.85-7.69$ (m, 2H, H3, H7), $7.21-7.00$ (m, 3H, H2, H8, H4), 1.41 (s, 18H, tBu)

${ }^{31} \mathrm{P}$ NMR $\left(25^{\circ} \mathbf{C}, \mathbf{d}_{6}\right.$-DMSO, 202MHz): $\delta$ [ppm] = 27.8 (d accompanied by ${ }^{77}$ Se satellites, ${ }^{1} \mathrm{~J}_{\mathrm{PSe}}$ $=434.5 \mathrm{~Hz},{ }^{2} \mathrm{~J}_{\mathrm{PP}}=18.7 \mathrm{~Hz}$ ), $21.5\left(\mathrm{~d}\right.$ accompanied by ${ }^{77}$ Se satellites, ${ }^{1} \mathrm{~J}_{\mathrm{PSe}}=437.1 \mathrm{~Hz},{ }^{2} \mathrm{~J}_{\mathrm{PP}}=$ $18.7 \mathrm{~Hz})$

Elemental analysis (\%): calcd. for 3.1: C 39.4, H 5.1, N 15.3; found: C 39.4, H 5.2, N 14.7

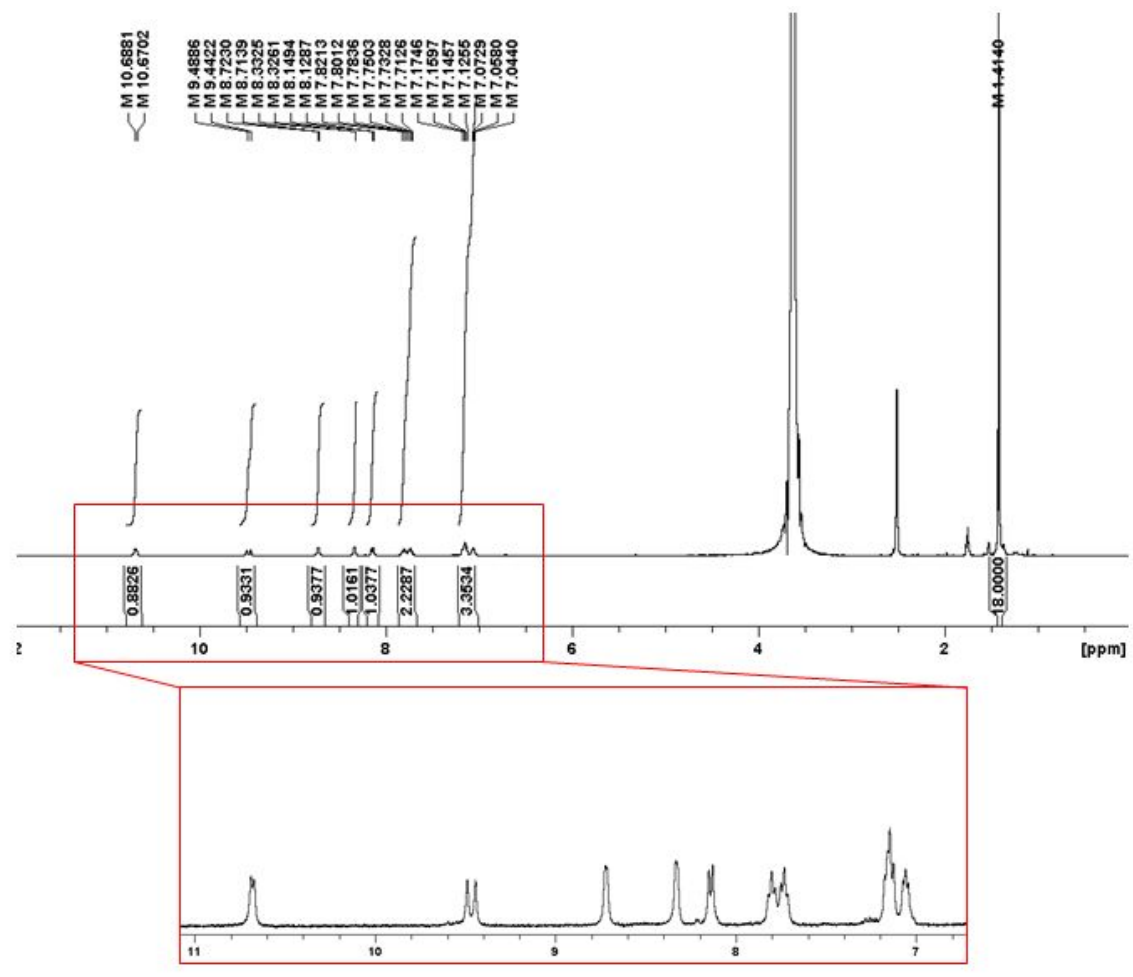

Figure S 3: ${ }^{1} \mathrm{H}$ NMR spectrum $\left(25^{\circ} \mathrm{C}, \mathrm{d}_{6}\right.$-DMSO, $\left.500 \mathrm{MHz}\right)$ of 2 


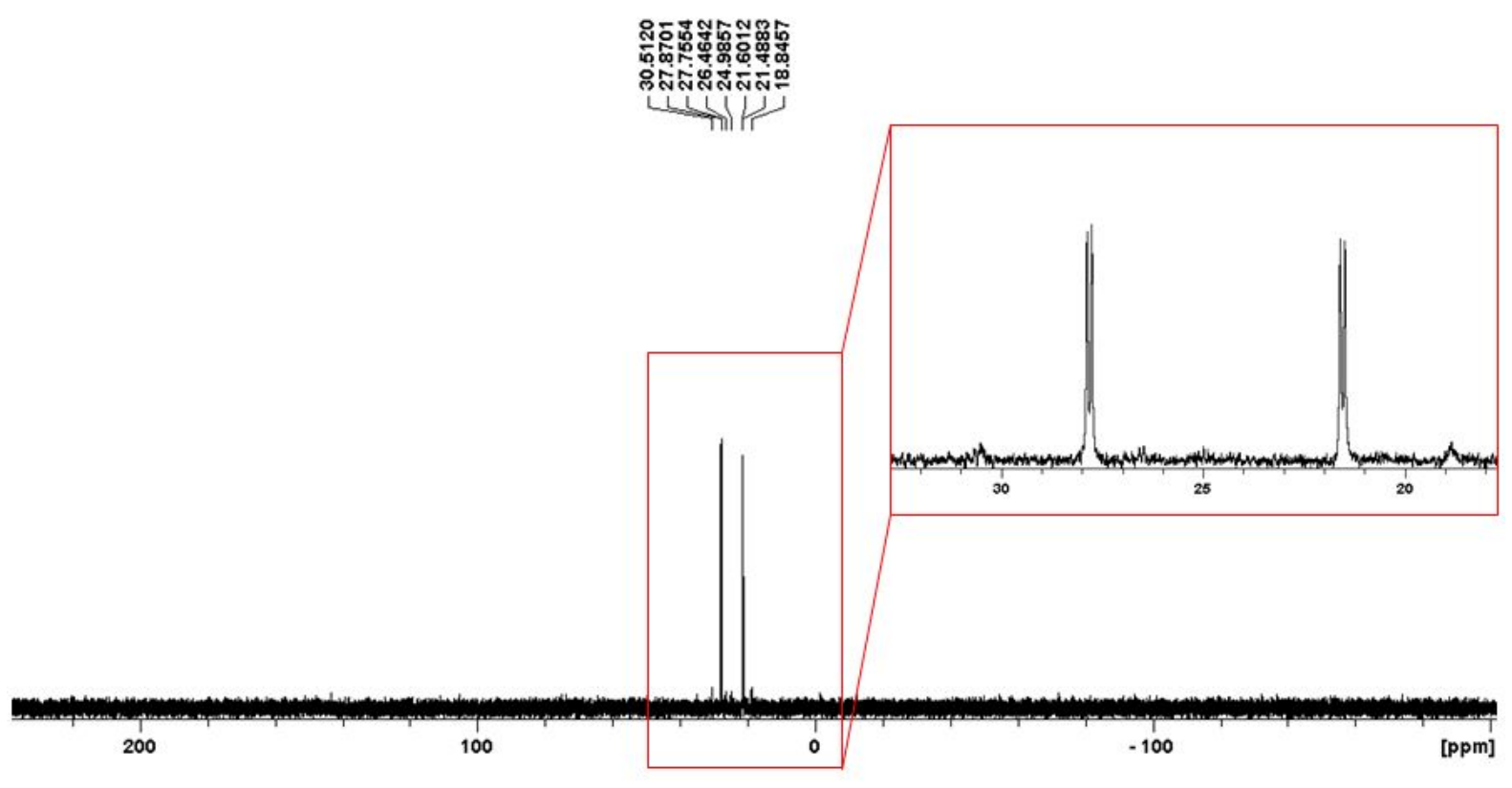

Figure S 4: ${ }^{31} \mathrm{P}$ NMR spectrum $\left(25^{\circ} \mathrm{C}, \mathrm{d}_{6}-\mathrm{DMSO}, 202 \mathrm{MHz}\right)$ of 2
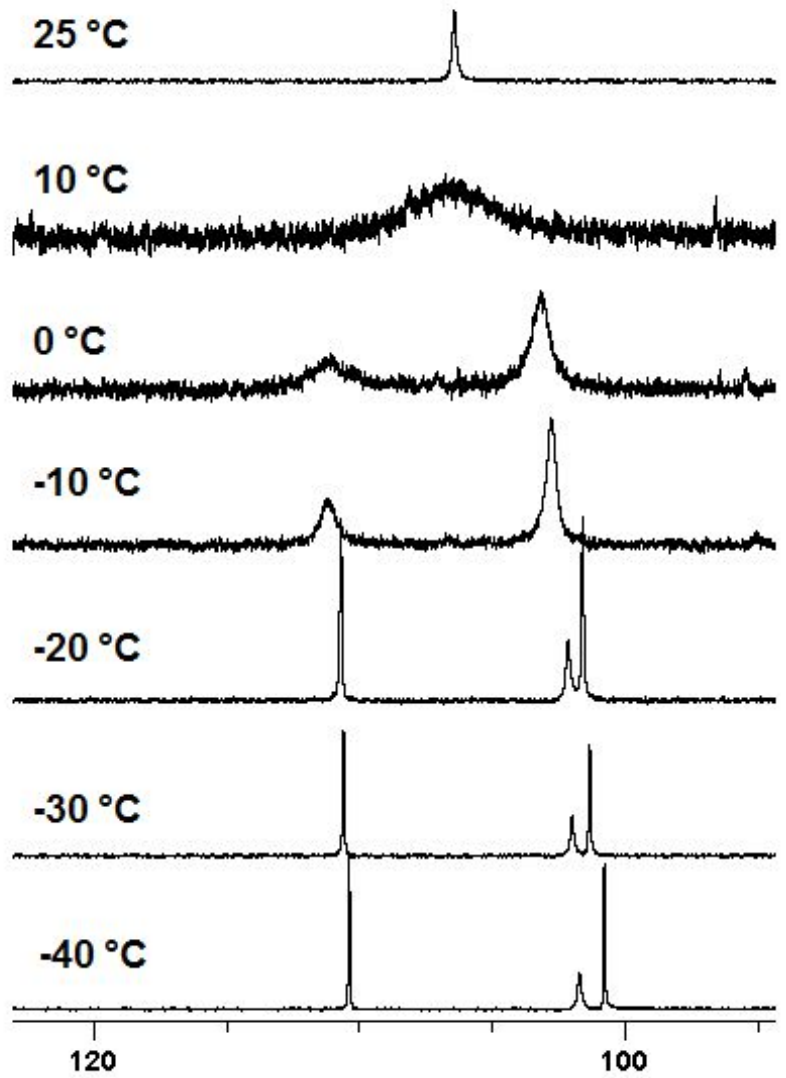

Figure S 5: Variable-temperature ${ }^{31} \mathrm{P}$ NMR spectrum (202MHz, $\mathrm{d}_{8}$-toluene) of 1 


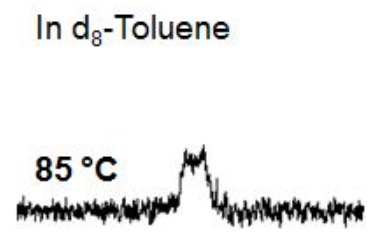

In $d_{6}$-DMSO

$105^{\circ} \mathrm{C}$

(n)

100

$95^{\circ} \mathrm{C}$

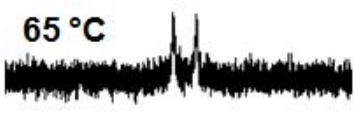

(4)

$90{ }^{\circ} \mathrm{C}$

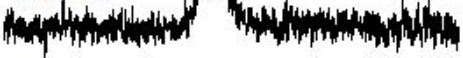
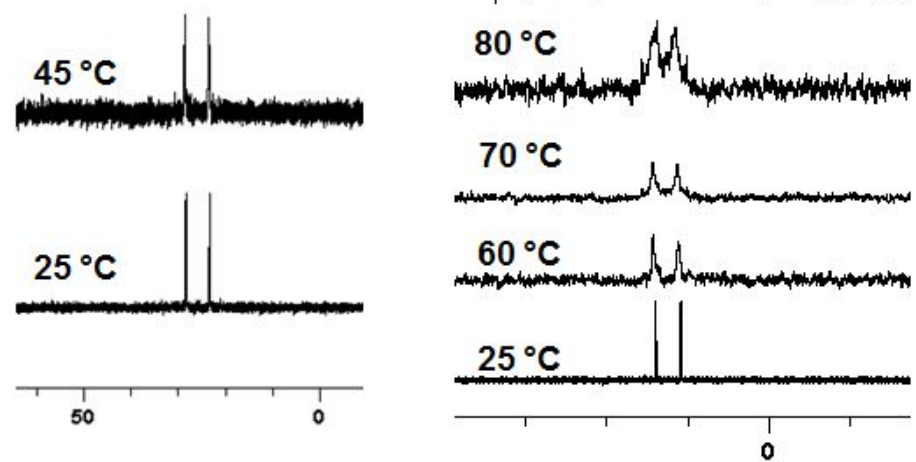

Figure S 6: Variable-temperature ${ }^{31} \mathrm{P}$ NMR spectrum $(202 \mathrm{MHz})$ of 2 in different solvents 


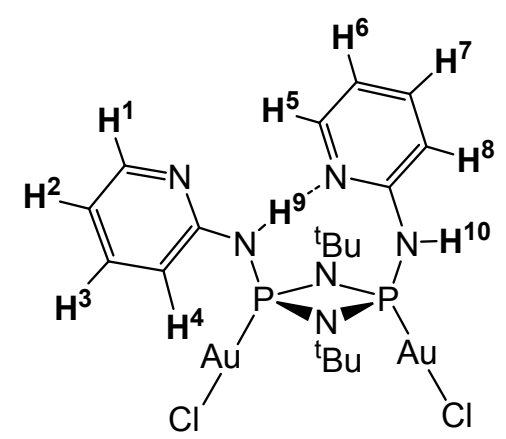

Synthesis of 3: Inside a $\mathrm{N}_{2}$ filled glovebox a Schlenk tube was charged with 1 (50 mg, $0.13 \mathrm{mmol})$ and $\left(\mathrm{Me}_{2} \mathrm{~S}\right) \mathrm{AuCl}_{2}(76 \mathrm{mg}, 0.26 \mathrm{mmol})$ and transferred to a Schlenk line. $3 \mathrm{ml}$ of THF were added and the mixture was stirred at room temperature for 10 minutes. Afterwards the reaction mixture was concentrated to approximately $1 \mathrm{ml}$ and layered with $10 \mathrm{ml}$ of $\mathrm{n}$-pentane. Storage of this mixture at room temperature for $72 \mathrm{~h}$ in the dark yielded colourless crystals suitable for X-ray diffraction which were isolated by filtration and dried in vacuo to yield $\mathbf{3}$ as a white crystalline solid (94 mg, 0.11mmol, 84\%).

${ }^{1} \mathrm{H}$ NMR $\left(25^{\circ} \mathrm{C}, \mathrm{CDCl}_{3}, 400 \mathrm{MHz}\right): \delta[\mathrm{ppm}]=10.06\left(\mathrm{~d},{ }^{2} \mathrm{~J}_{\mathrm{PH}}=9.5 \mathrm{~Hz}, 1 \mathrm{H}, \mathrm{H} 9\right), 8.53\left(\mathrm{~d},{ }^{3} \mathrm{~J}_{\mathrm{HH}}=\right.$ $4 \mathrm{~Hz}, 1 \mathrm{H}, \mathrm{H} 5), 8.34\left(\mathrm{~d}, \mathrm{~J}_{\mathrm{HH}}=3.9 \mathrm{~Hz}, 1 \mathrm{H}, \mathrm{H} 1\right), 7.90\left(\mathrm{~d},{ }^{2} \mathrm{~J}_{\mathrm{PH}}=22.4 \mathrm{~Hz}, 1 \mathrm{H}, \mathrm{H} 10\right), 7.76\left(\mathrm{t},{ }^{3} \mathrm{~J}_{\mathrm{HH}}=\right.$ $7.7 \mathrm{~Hz}, 1 \mathrm{H}, \mathrm{H} 3), 7.67\left(\mathrm{t},{ }^{3} \mathrm{~J}_{\mathrm{HH}}=7.7 \mathrm{~Hz}, 1 \mathrm{H}, \mathrm{H} 7\right), 7.57\left(\mathrm{~d},{ }^{3} \mathrm{~J}_{\mathrm{HH}}=7.7 \mathrm{H}, 1 \mathrm{H}, \mathrm{H} 4\right), 7.15\left(\mathrm{t},{ }^{3} \mathrm{~J}_{\mathrm{HH}}=\right.$ $6.0 \mathrm{~Hz}, 1 \mathrm{H}, \mathrm{H} 6), 7.10-6.97(\mathrm{~m}, 2 \mathrm{H}, \mathrm{H} 2, \mathrm{H} 5), 1.54\left(\mathrm{~s}, 18 \mathrm{H},{ }^{\mathrm{t}} \mathrm{Bu}\right)$

${ }^{31} \mathrm{P}$ NMR $\left(25^{\circ} \mathrm{C}, \mathrm{CDCl}_{3}, 202 \mathrm{MHz}\right): \delta[p p m]=79.5\left(\mathrm{~d}, \mathrm{~J}_{\mathrm{PP}}=15 \mathrm{~Hz}\right), 66.5\left(\mathrm{~d}, \mathrm{~J}_{\mathrm{PP}}=15 \mathrm{~Hz}\right)$

No consistent elemental analysis could be obtained.
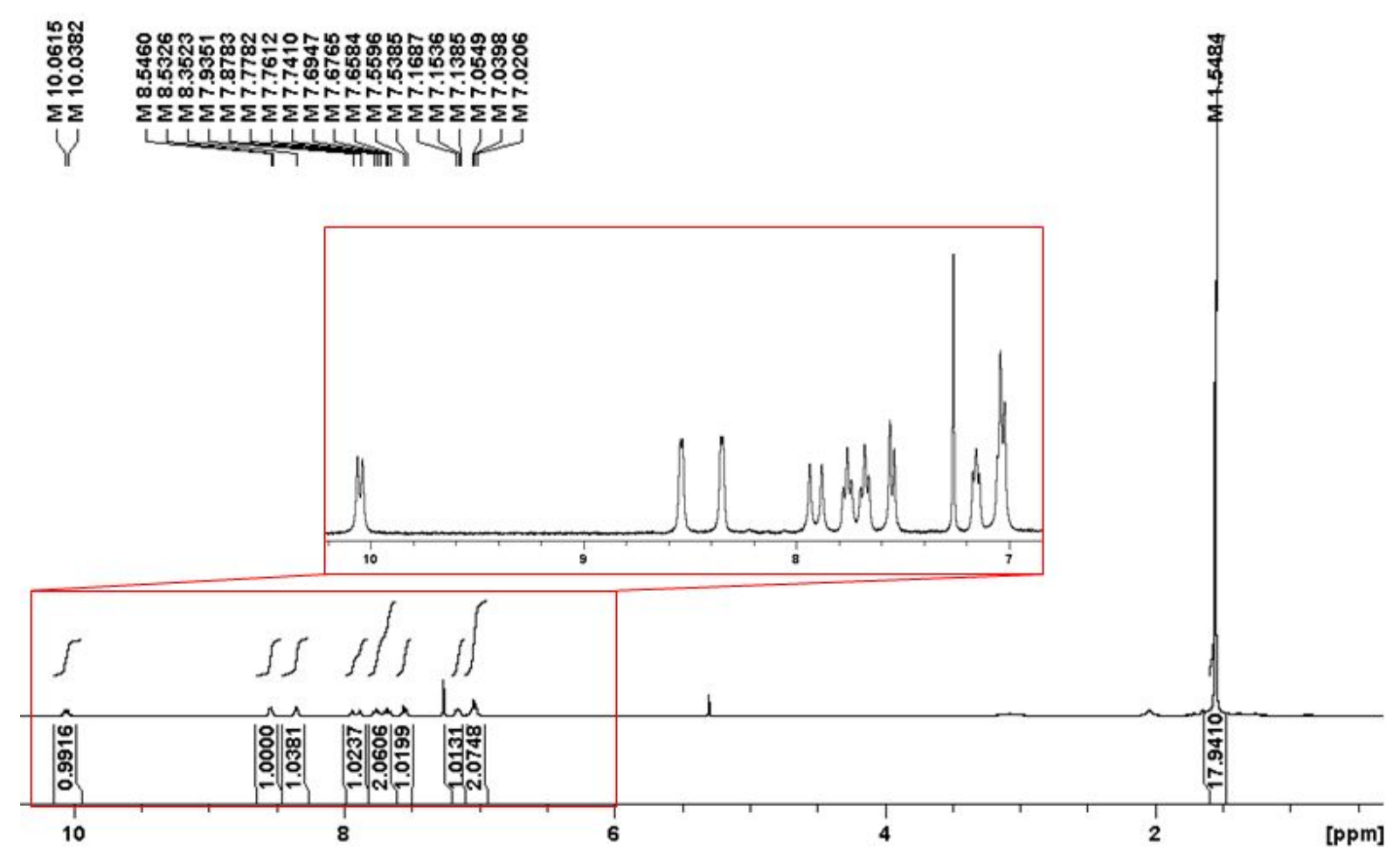

Figure S 7: ${ }^{1} \mathrm{H}$ NMR spectrum $\left(25^{\circ} \mathrm{C}, \mathrm{CDCl}_{3}, 400 \mathrm{MHz}\right)$ of 3 


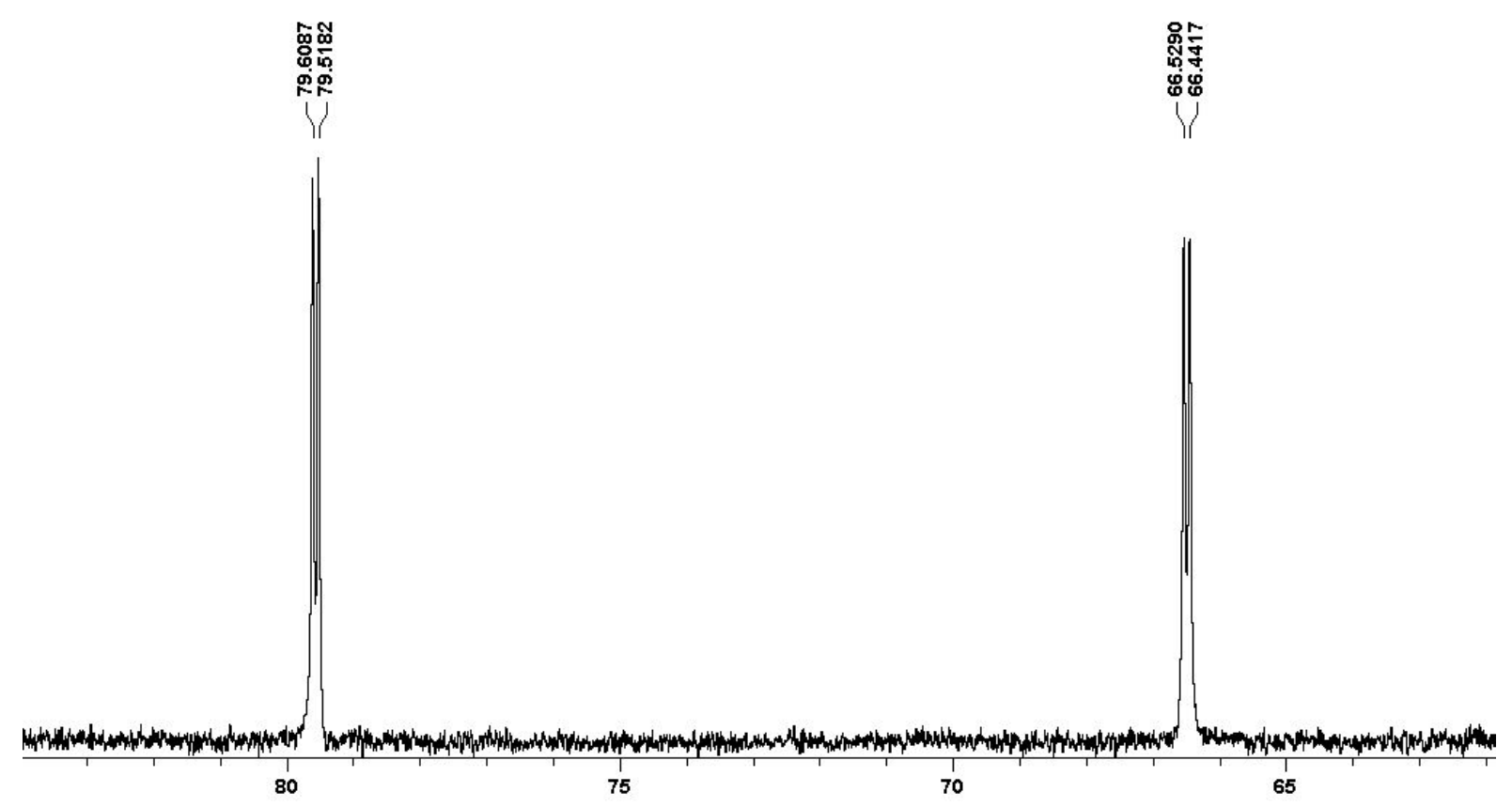

Figure S 8: ${ }^{31} \mathrm{P}$ NMR spectrum $\left(25^{\circ} \mathrm{C}, \mathrm{CDCl}_{3}, 202 \mathrm{MHz}\right)$ of 3 


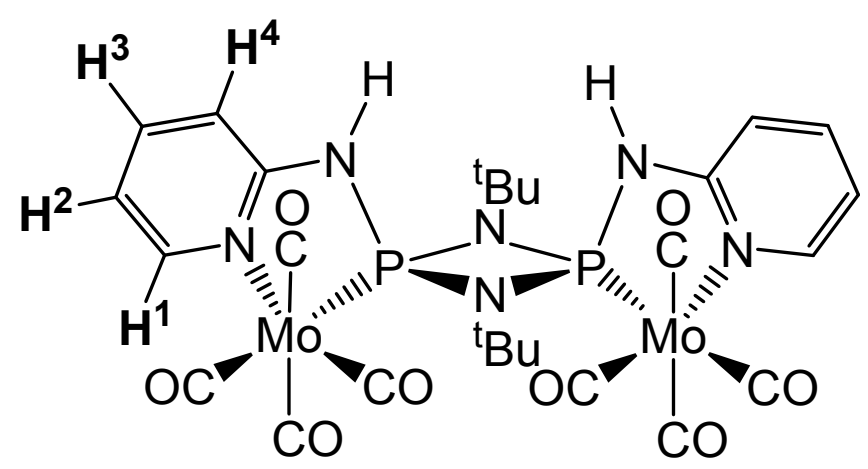

Synthesis of 4: Inside a $\mathrm{N}_{2}$ filled glovebox a Schlenk tube was charged with 4 (200 mg, $0.52 \mathrm{mmol})$ and $(\mathrm{CO})_{4} \mathrm{Mo}$ (Piperidine $)_{2}(412 \mathrm{mg}, 1.10 \mathrm{mmol})$ and transferred to a Schlenk line. $50 \mathrm{ml}$ of $\mathrm{CH}_{2} \mathrm{Cl}_{2}$ were added and the mixture was stirred at $40^{\circ} \mathrm{C}$ for $2 \mathrm{~h}$. Afterwards all solvent was removed in vacuo and the resulting yellow residue was dissolved in $40 \mathrm{ml}$ of warm $\mathrm{CH}_{3} \mathrm{CN}$. The solvent was removed in vacuo until the precipitation of a yellow solid was observed which was gently heated back into solution. Storage of the solution at $-20{ }^{\circ} \mathrm{C}$ led to the formation of yellow crystals suitable for $\mathrm{X}$-ray diffraction which were isolated by filtration and dried in vacuo to yield $4 \cdot \mathrm{CH}_{3} \mathrm{CN}$ as a yellow crystalline powder (152mg, $0.19 \mathrm{mmol}, 36 \%$ ).

${ }^{1} \mathbf{H}$ NMR $\left(25^{\circ} \mathbf{C}, \mathbf{d}_{6}-\mathrm{DMSO}, \mathbf{5 0 0 M H z}\right): \delta[p p m]=9.10(\mathrm{bs}, 2 \mathrm{H}, \mathrm{NH}), 8.41\left(\mathrm{~d}, 2 \mathrm{H},{ }^{3} \mathrm{~J}_{\mathrm{HH}}=5.5 \mathrm{~Hz}\right.$, $\mathrm{H} 1), 7.79\left(\mathrm{t}, 2 \mathrm{H},{ }^{3} \mathrm{~J}_{\mathrm{HH}}=7.3 \mathrm{~Hz}, \mathrm{H} 3\right), 6.95\left(\mathrm{~d}, 2 \mathrm{H},{ }^{3} \mathrm{~J}_{\mathrm{HH}}=5.5 \mathrm{~Hz}, \mathrm{H} 4\right), 6.88\left(\mathrm{t}, 2 \mathrm{H},{ }^{3} \mathrm{~J}_{\mathrm{HH}}=6.8 \mathrm{~Hz}\right.$, $\mathrm{H} 2), 1.48\left(\mathrm{~s}, 18 \mathrm{H},{ }^{\mathrm{t}} \mathrm{Bu}\right)$

${ }^{31} \mathrm{P}$ NMR $\left(25^{\circ} \mathbf{C}, \mathbf{d}_{6}-\mathrm{DMSO}, \mathbf{2 0 2} \mathrm{MHz}\right): \delta[\mathrm{ppm}]=137.9$ (s)

Elemental analysis (\%) calcd. for $4 \cdot \mathrm{CH}_{3} \mathrm{CN}$ : C 39.7, $\mathrm{H} 3.7, \mathrm{~N} 11.6$; found $\mathrm{C} 41.1, \mathrm{H} 4.6, \mathrm{~N}$ 10.8 


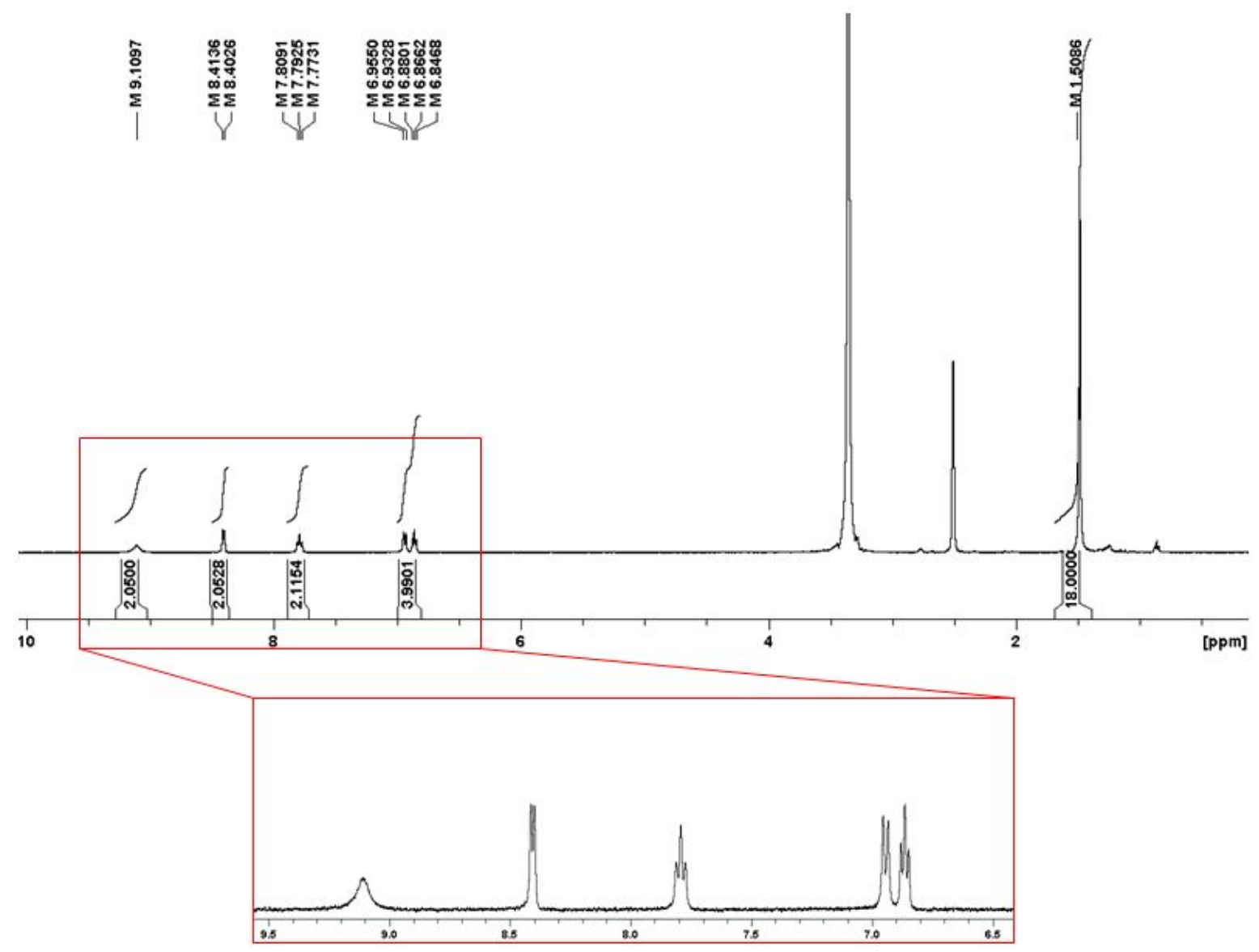

Figure S 9: ${ }^{1} \mathrm{H}$ NMR spectrum $\left(25^{\circ} \mathrm{C}, \mathrm{d}_{6}\right.$-DMSO, $\left.500 \mathrm{MHz}\right)$ of 4

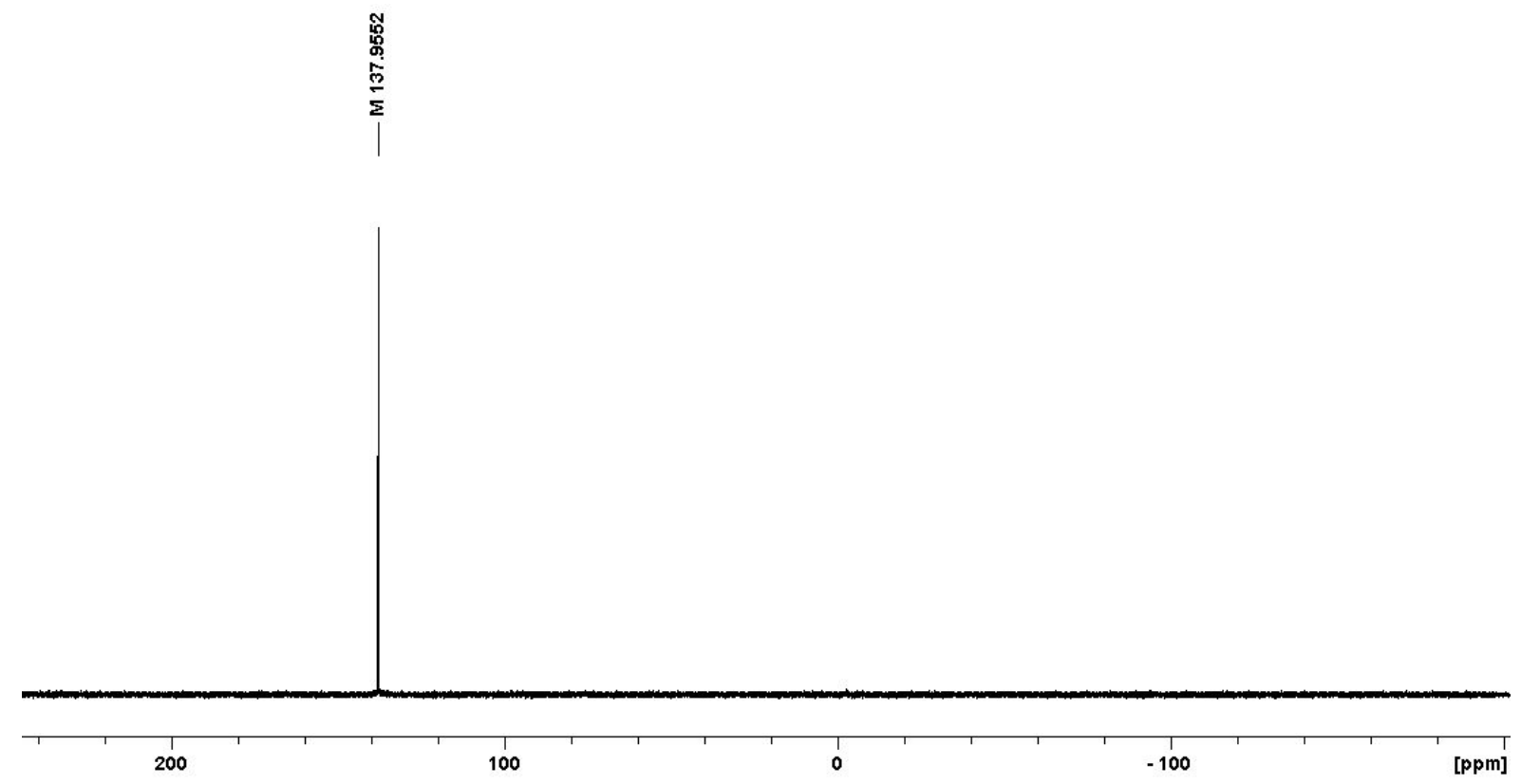

Figure S 10: ${ }^{31} \mathrm{P}$ NMR spectrum $\left(25^{\circ} \mathrm{C}, \mathrm{d}_{6}-\mathrm{DMSO}, 202 \mathrm{MHz}\right)$ of 4 


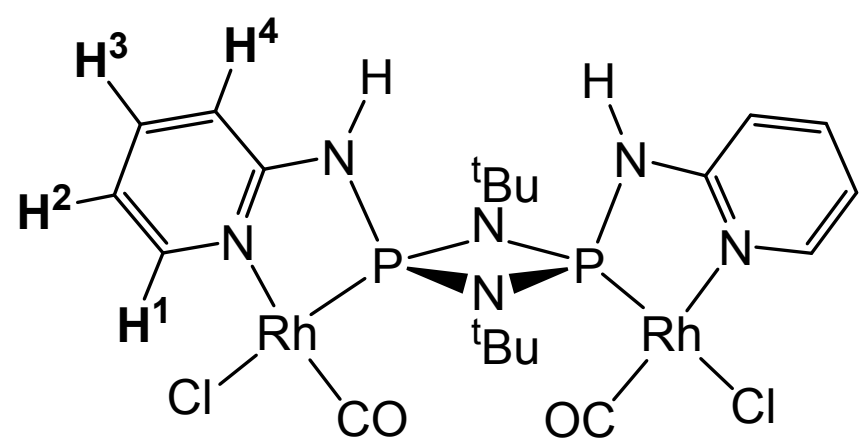

Synthesis of 5: Inside a $\mathrm{N}_{2}$ filled glovebox a Schlenk tube was charged with 1 (100 mg, $0.26 \mathrm{mmol})$ and $\mathrm{Rh}_{2}(\mathrm{CO})_{4} \mathrm{Cl}_{2}(101 \mathrm{mg}, 0.26 \mathrm{mmol})$ and transferred to a Schlenk line. $20 \mathrm{ml}$ of $\mathrm{CH}_{2} \mathrm{Cl}_{2}$ were added and the mixture was stirred at room temperature for $30 \mathrm{~min}$. All volatiles were removed in vacuo yielding $\mathbf{5}$ as a yellow powder which was dried in vacuo $(184 \mathrm{mg}$, quantitative). This powder was pure as established by multinuclear NMR. The material was recrystallized from $\mathrm{CH}_{3} \mathrm{CN} / \mathrm{DMSO}$ solution yielding $5 \cdot \mathrm{DMSO} \cdot 0.5 \mathrm{MeCN}$ as yellow crystals suitable for X-ray diffraction. Placing 5.DMSO $0.5 \mathrm{MeCN}$ under vacuum during isolation removes the partial MeCN solvation of the lattice (isolated material 5.DMSO, $110 \mathrm{mg}$, $0.15 \mathrm{mmol}, 59 \%)$.

${ }^{1} \mathrm{H}$ NMR $\left(25^{\circ} \mathrm{C}, \mathrm{CD}_{2} \mathrm{Cl}_{2}, \mathbf{5 0 0 M H z}\right): \delta[\mathrm{ppm}]=8.96$ (bs, 2H, H1), 8.86 (bs, 2H, NH), 7.69 (pt, $\left.2 \mathrm{H},{ }^{3} \mathrm{~J}_{\mathrm{HH}}=7.7 \mathrm{~Hz}, \mathrm{H} 3\right), 7.25\left(\mathrm{~d}, 2 \mathrm{H},{ }^{3} \mathrm{~J}_{\mathrm{HH}}=7.7 \mathrm{~Hz}, \mathrm{H} 4\right), 7.69\left(\mathrm{pt}, 2 \mathrm{H},{ }^{3} \mathrm{~J}_{\mathrm{HH}}=7.7 \mathrm{~Hz}, \mathrm{H} 2\right), 1.65(\mathrm{~s}$, $\left.18 \mathrm{H},{ }^{\mathrm{t}} \mathrm{Bu}\right)$

${ }^{31} \mathrm{P}$ NMR $\left(25^{\circ} \mathrm{C}, \mathrm{CD}_{2} \mathrm{Cl}_{2}, 202 \mathrm{MHz}\right): \delta[\mathrm{ppm}]=106.0-108.0(\mathrm{~m})$

Elemental analysis (\%) calcd. for 5.DMSO: C 33.0 H 4.3 N 10.5; found: C 33.3 H 4.3 N 10.7

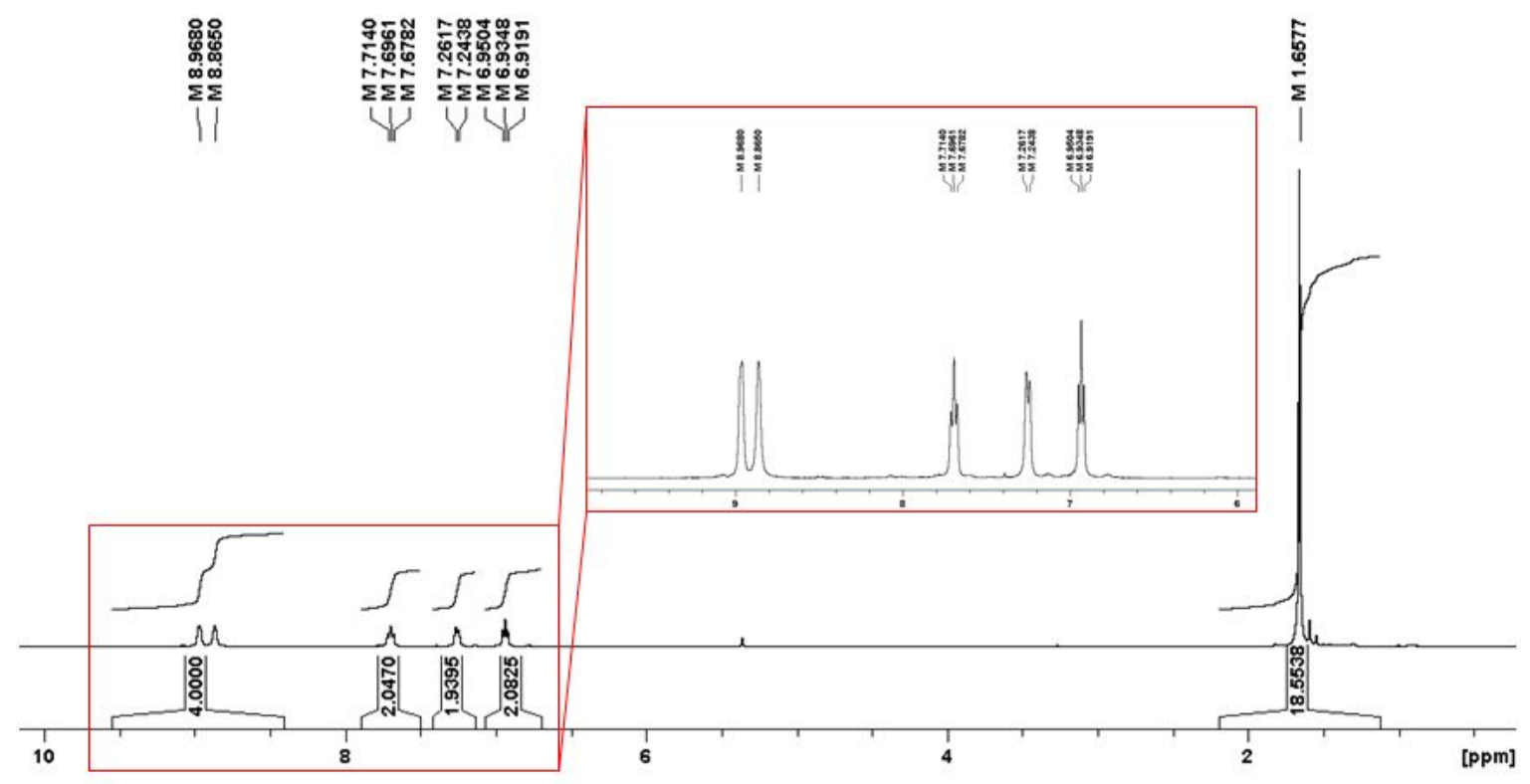

Figure S 11: ${ }^{1} \mathrm{H}$ NMR spectrum $\left(25^{\circ} \mathrm{C}, \mathrm{CD}_{2} \mathrm{Cl}_{2}, 500 \mathrm{MHz}\right)$ of 5 


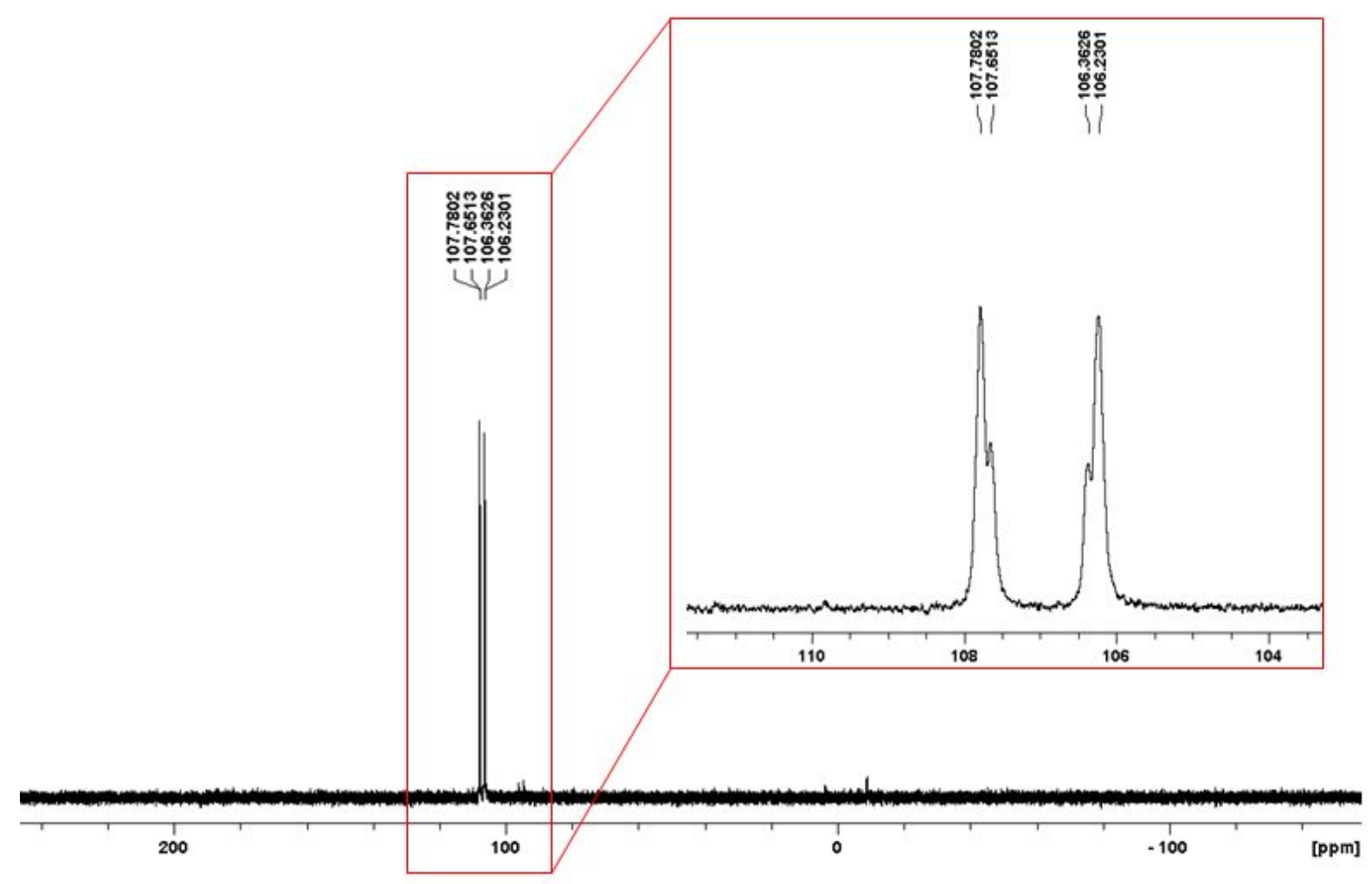

Figure S 12: ${ }^{31} \mathrm{P}$ NMR spectrum $\left(25^{\circ} \mathrm{C}, \mathrm{CD}_{2} \mathrm{Cl}_{3}, 202 \mathrm{MHz}\right)$ of 5
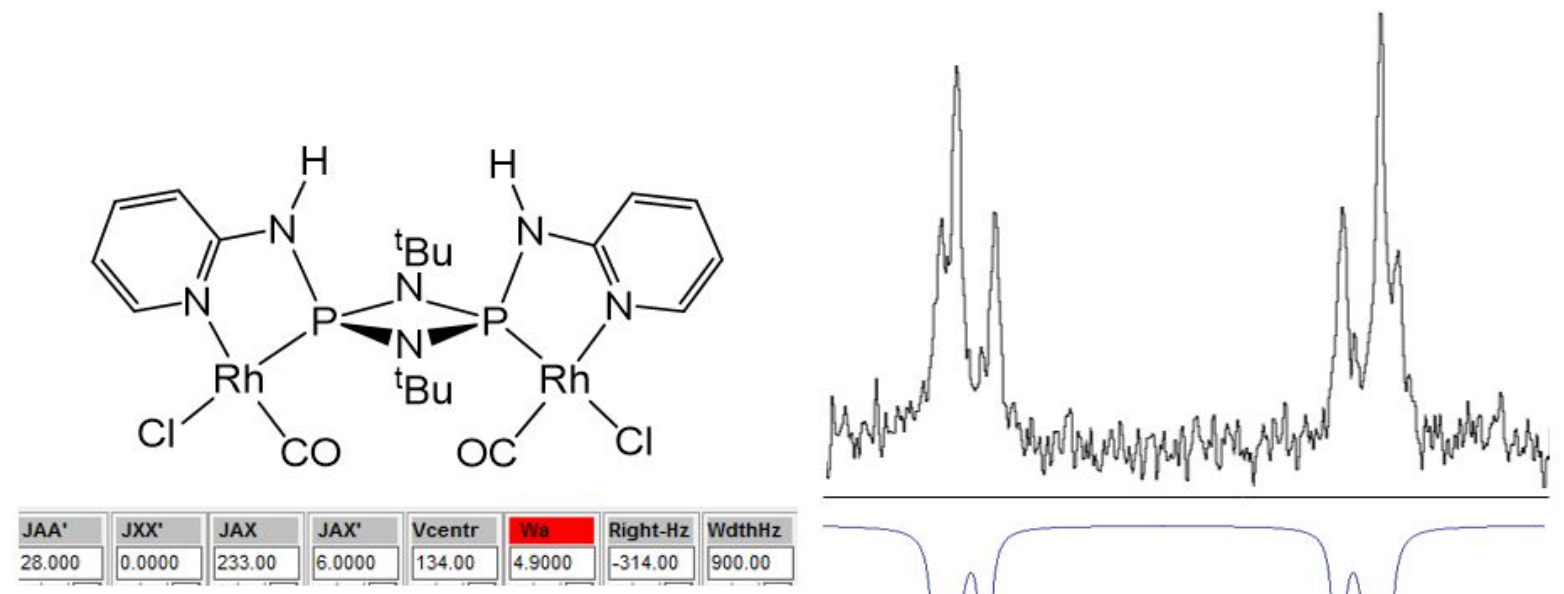

\begin{tabular}{|c|c|c|c|c|c|}
\hline 28.000 & 0.0000 & 233.00 & 6.0000 & 134,00 & 14000 \\
\hline
\end{tabular}

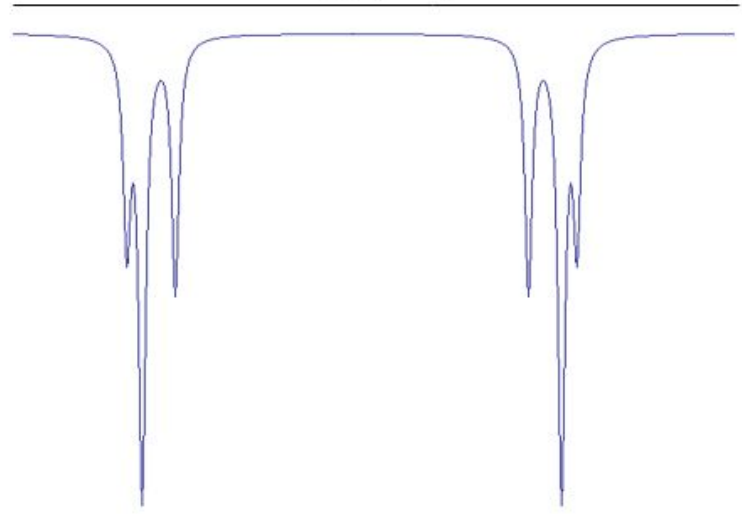

Figure S 13: ${ }^{31} \mathrm{P}$ NMR spectrum $\left(25^{\circ} \mathrm{C}, \mathrm{d}_{6}-\mathrm{DMSO}, 202 \mathrm{MHz}\right)$ of 5 and simulated spectrum (blue) with parameters. 


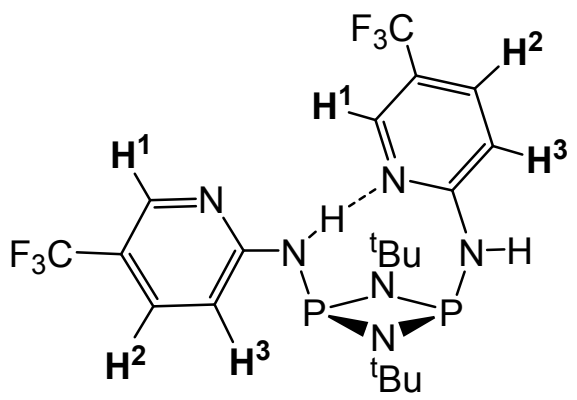

Synthesis of 6: Inside a $\mathrm{N}_{2}$ filled glovebox a Schlenk tube was charged with $\left[\mathrm{P}\left(\mu-\mathrm{N}^{\mathrm{t} B u}\right) \mathrm{Cl}_{2}\right.$ $(2.75 \mathrm{~g}, 10 \mathrm{mmol})$ and transferred to a Schlenk line. $20 \mathrm{ml}$ of THF and 2-amino-5(trifluoromethyl)pyridine (3.24g, $20 \mathrm{mmol}, 2$ equivalents) in $20 \mathrm{ml} \mathrm{THF}$ and $20 \mathrm{ml} \mathrm{Et}_{3} \mathrm{~N}$ were added subsequently at room temperature. The resulting mixture was then stirred overnight at $40{ }^{\circ} \mathrm{C}$. Afterwards the solvent was removed in vacuo and the resulting solid mixture was extracted with $80 \mathrm{ml}$ of hexane. The solvent was removed in vacuo until the precipitation of a white solid was observed which was gently heated back into solution. Storage of the solution at $-20^{\circ} \mathrm{C}$ led to the formation of colourless crystal suitable for X-ray diffraction which were isolated by filtration and dried in vacuo to yield 6 as a colourless crystalline powder $(1.81 \mathrm{~g}$, $3.48 \mathrm{mmol}, 35 \%)$.

${ }^{1} \mathrm{H} \mathrm{NMR}\left(25^{\circ} \mathrm{C}, \mathrm{CD}_{3} \mathrm{Cl}, \mathbf{5 0 0 M H z}\right): \delta[p p m]=8.48(\mathrm{~s}, 2 \mathrm{H}, \mathrm{H} 1), 7.70\left(\mathrm{dd}, 2 \mathrm{H},{ }^{2} \mathrm{~J}_{\mathrm{HH}}=8.6 \mathrm{~Hz},{ }^{4} \mathrm{~J}_{\mathrm{HH}}=\right.$ $2.6 \mathrm{~Hz} \mathrm{H} 2), 7.02\left(\mathrm{~d}, 2 \mathrm{H},{ }^{3} \mathrm{~J}_{\mathrm{HH}}=8.6 \mathrm{~Hz}, \mathrm{H} 3\right), 6.62(\mathrm{bs}, 2 \mathrm{H}, \mathrm{NH}), 1.26\left(\mathrm{~s}, 18 \mathrm{H},{ }^{\mathrm{t}} \mathrm{Bu}\right)$

${ }^{31} \mathrm{P}$ NMR $\left(25^{\circ} \mathrm{C}, \mathrm{CD}_{3} \mathrm{Cl}, 202 \mathrm{MHz}\right): \delta[\mathrm{ppm}]=109.79(\mathrm{~s})$.

Elemental analysis (\%) calcd. for 6: C 45.6, H 5.0, N 16.0; found: C 45.6 H 5.2 N 15.8

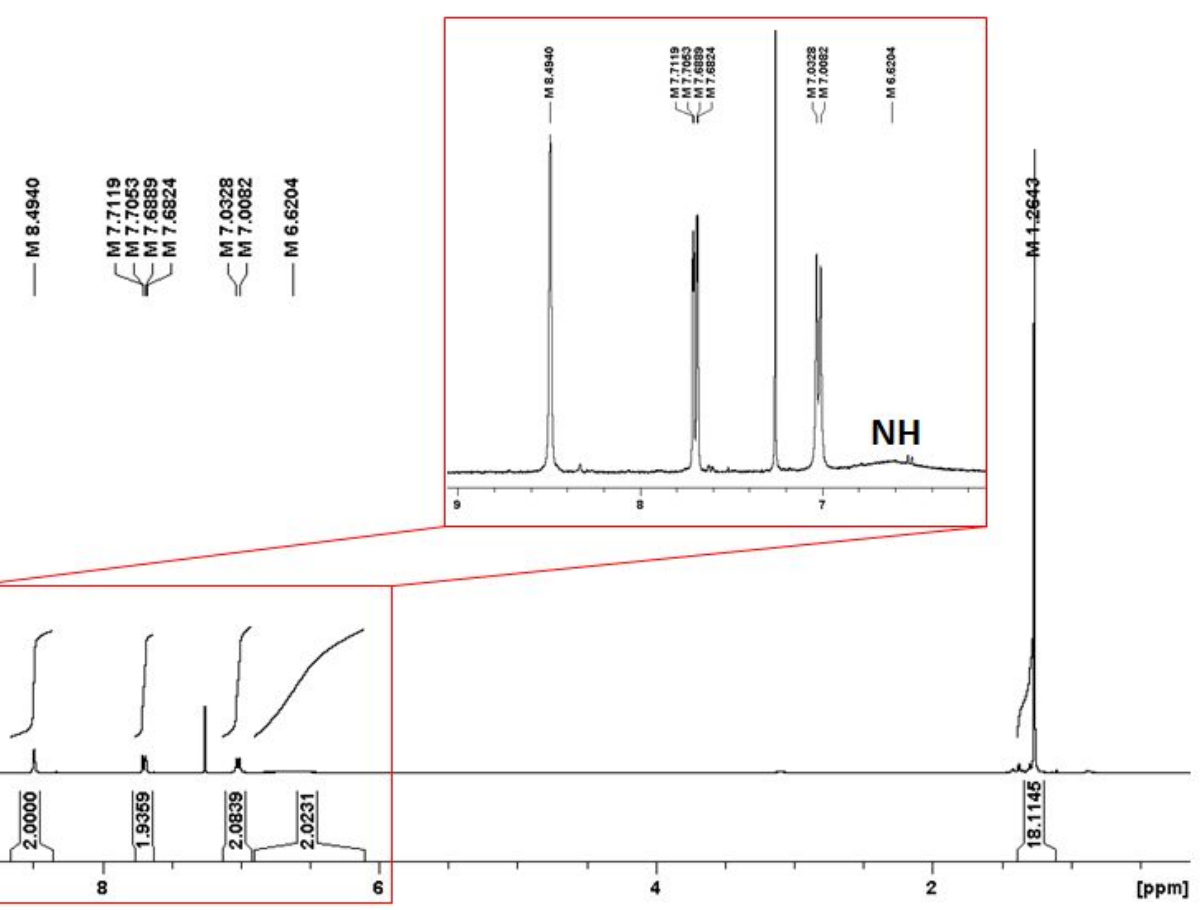

Figure S 14: ${ }^{1} \mathrm{H}$ NMR spectrum $\left(25^{\circ} \mathrm{C}, \mathrm{CDCl}_{3}, 500 \mathrm{MHz}\right)$ of 6 


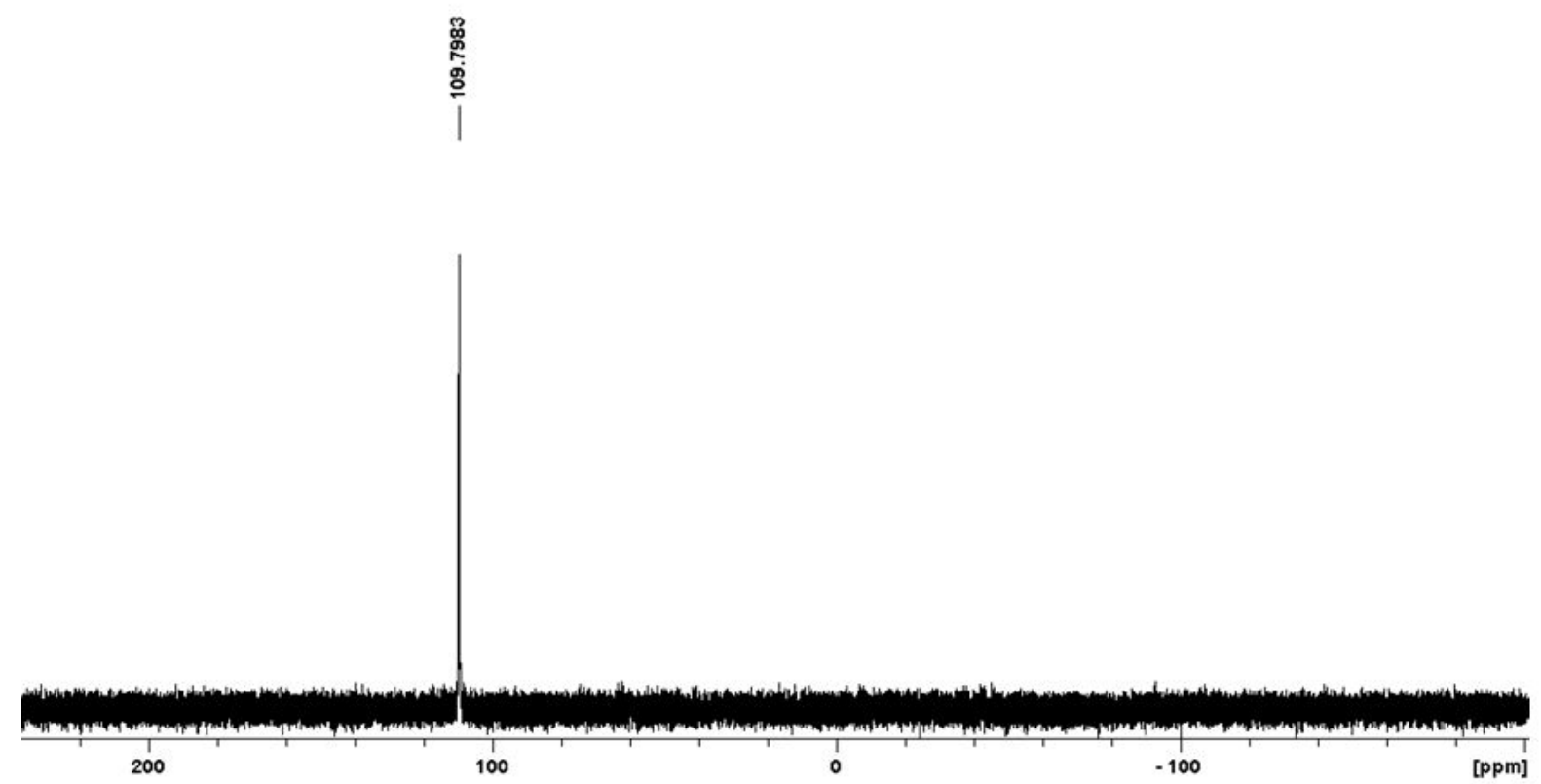

Figure S 15: ${ }^{31} \mathrm{P}$ NMR spectrum $\left(25^{\circ} \mathrm{C}, \mathrm{CDCl}_{3}, 202 \mathrm{MHz}\right)$ of 6

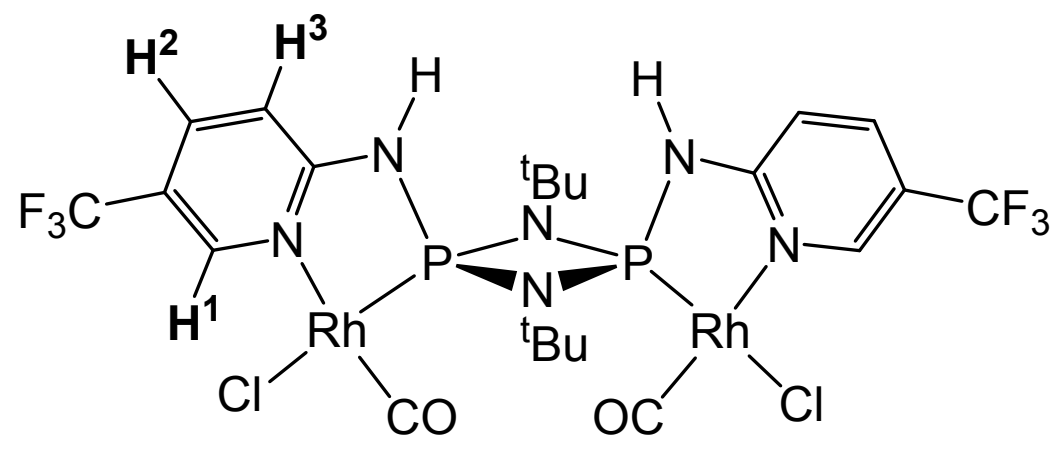

Synthesis of 7: Inside a $\mathrm{N}_{2}$ filled glovebox a Schlenk tube was charged with $6(100 \mathrm{mg}$, $0.18 \mathrm{mmol})$ and $\mathrm{Rh}_{2}(\mathrm{CO})_{4} \mathrm{Cl}_{2}(70 \mathrm{mg}, 018)$ and transferred to a Schlenk line. $20 \mathrm{ml}$ of $\mathrm{CH}_{2} \mathrm{Cl}_{2}$ were added and the mixture was stirred at room temperature for $30 \mathrm{~min}$. All volatiles were removed in vacuo yielding 7 as a yellow powder (150mg, $0.175 \mathrm{mmol}, 98 \%$ ).

${ }^{1} \mathbf{H}$ NMR $\left(2^{\circ} \mathbf{C}, \mathbf{d}_{6}\right.$-DMSO, 500MHz): $\delta[\mathrm{ppm}]=9.94(\mathrm{~s}, 2 \mathrm{H}, \mathrm{NH}), 9.35$ (s, 2H, H1), 8.29 (dd, $\left.2 \mathrm{H},{ }^{3} \mathrm{~J}_{\mathrm{HH}}=8.8 \mathrm{~Hz},{ }^{4} \mathrm{~J}_{\mathrm{HH}}=1.9 \mathrm{~Hz}, \mathrm{H} 2\right), 7.27\left(\mathrm{~d}, 2 \mathrm{H},{ }^{3} \mathrm{~J}_{\mathrm{HH}}=8.8 \mathrm{~Hz}, \mathrm{H} 3\right), 1.53\left(\mathrm{~s}, 18 \mathrm{H},{ }^{\mathrm{t}} \mathrm{Bu}\right)$

${ }^{31} \mathbf{P}$ NMR $\left(25^{\circ} \mathbf{C}, \mathbf{d}_{6}\right.$-DMSO, 202MHz): $\delta[\mathrm{ppm}]=110.1-108.4(\mathrm{~m})$

Elemental analysis (\%) calcd. for 7: C 30.9 H 3.1 N 9.8; found C 30.9 H 3.1, N 9.2 


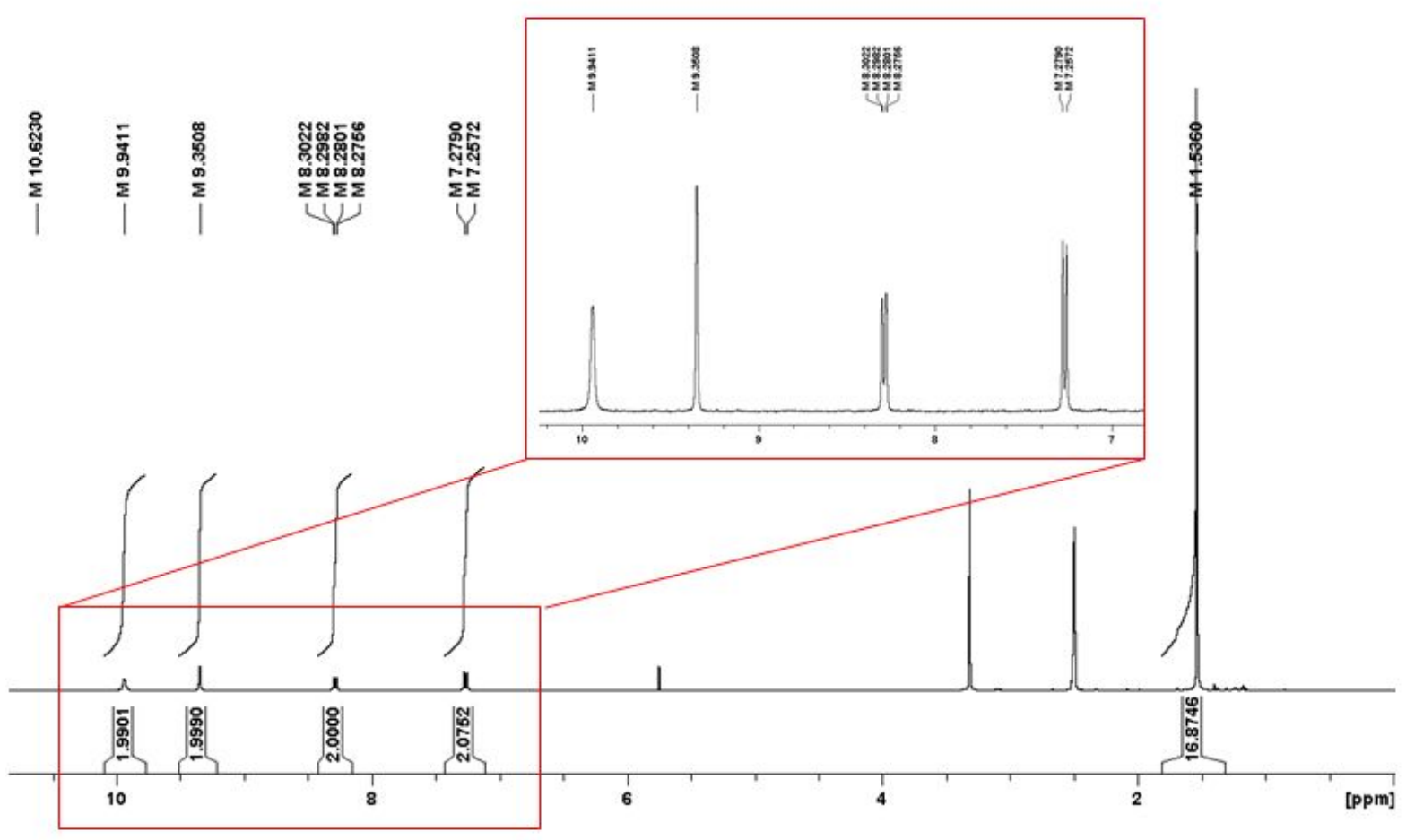

Figure S 16: ${ }^{1} \mathrm{H}$ NMR spectrum $\left(25^{\circ} \mathrm{C}, \mathrm{d}_{6}-\mathrm{DMSO}, 500 \mathrm{MHz}\right)$ of 7

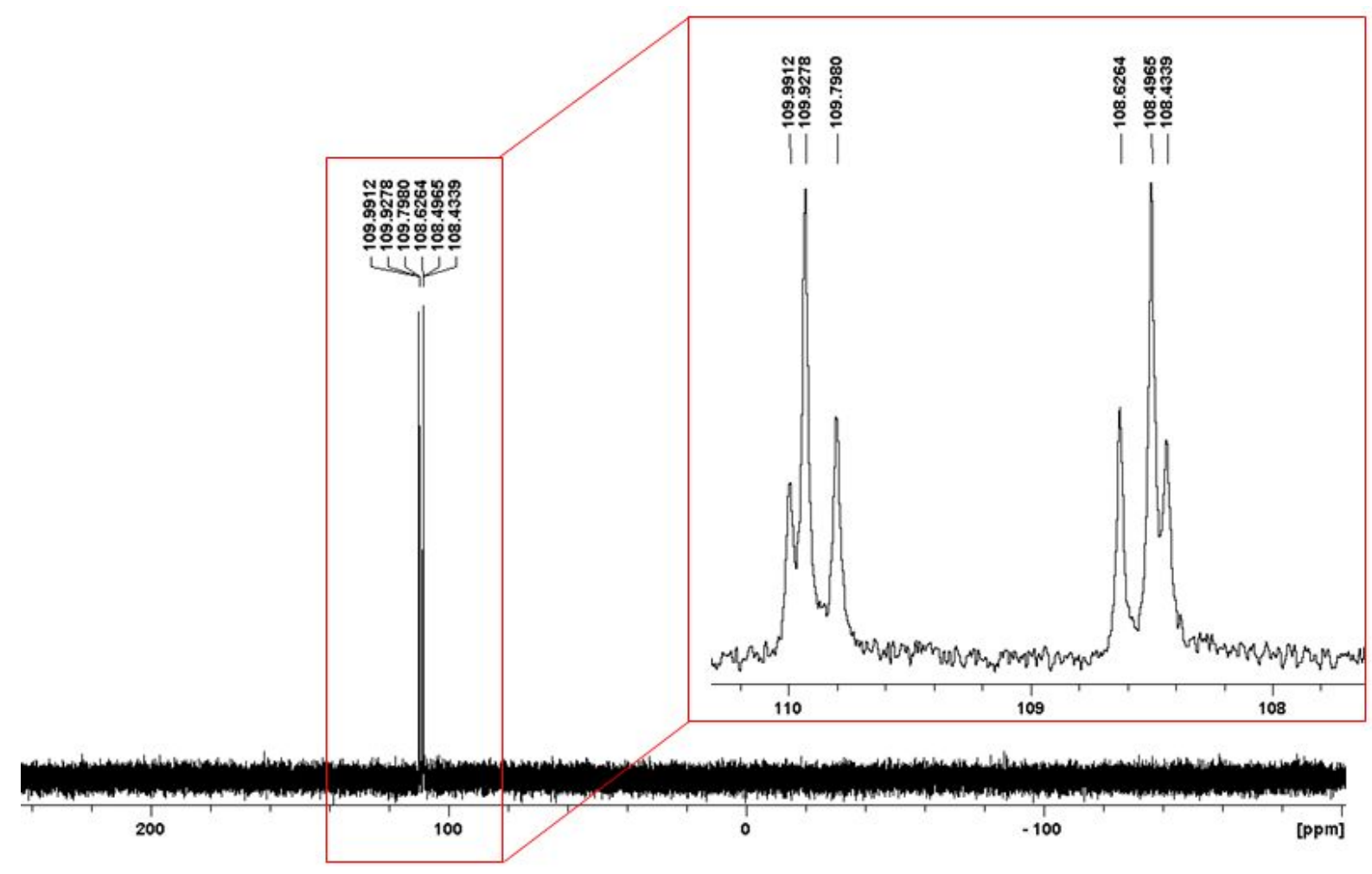

Figure S 17: ${ }^{31} \mathrm{P}$ NMR spectrum $\left(25^{\circ} \mathrm{C}, \mathrm{d}_{6}-\mathrm{DMSO}, 202 \mathrm{MHz}\right)$ of 7 


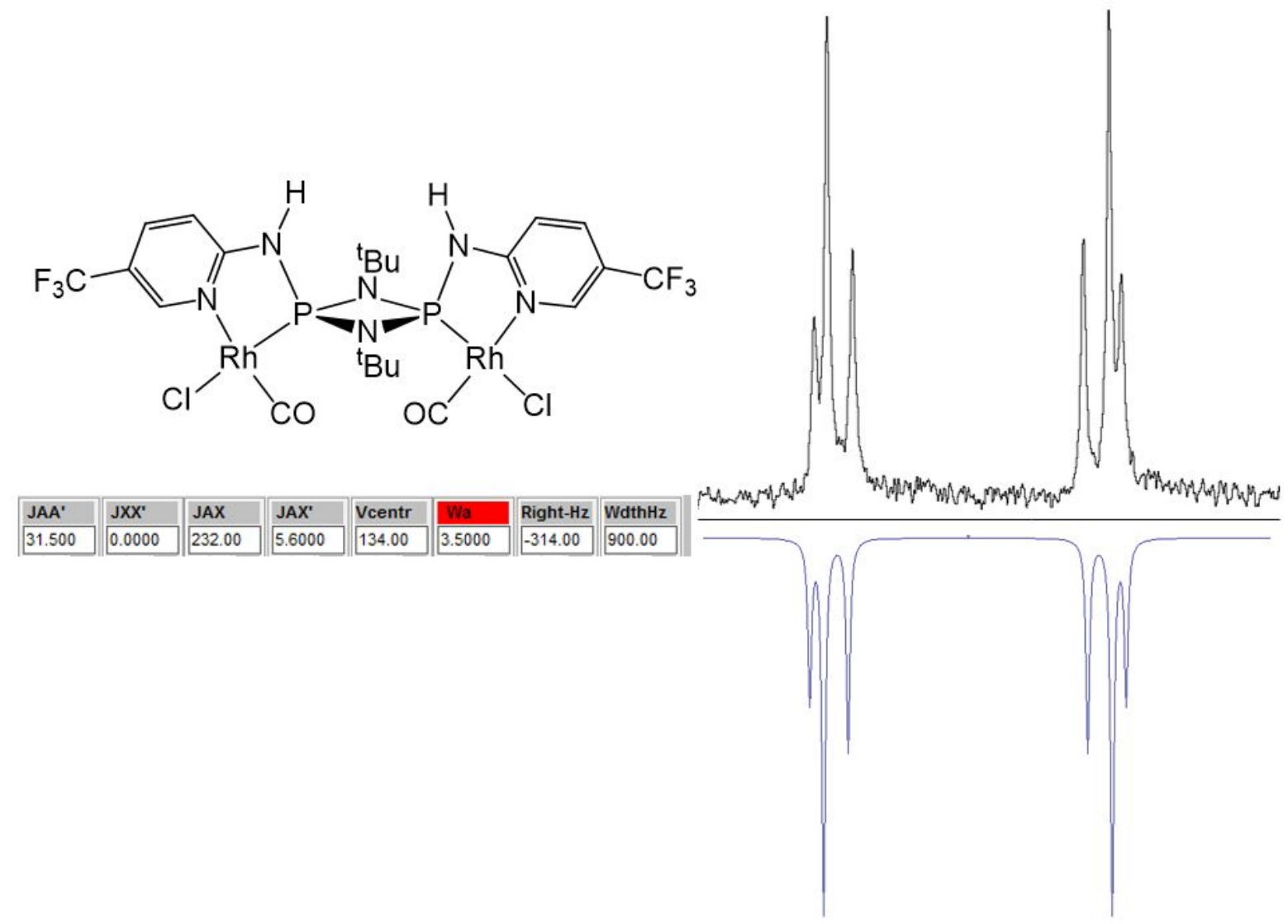

Figure S 18: ${ }^{31} \mathrm{P}$ NMR spectrum $\left(25^{\circ} \mathrm{C}, \mathrm{d}_{6}-\mathrm{DMSO}, 202 \mathrm{MHz}\right)$ of 7 and simulated spectrum (blue) with parameters.

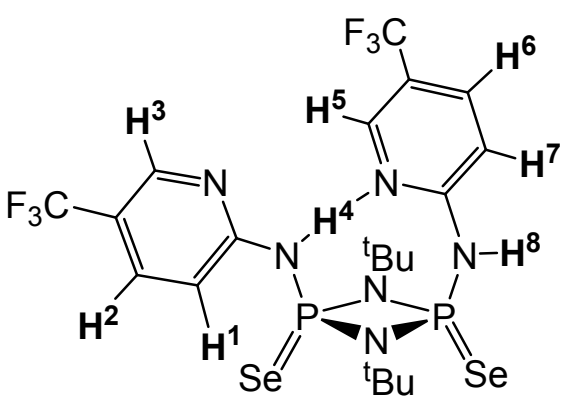

Synthesis of 9: Inside a $\mathrm{N}_{2}$ filled glovebox a Schlenk tube was charged with 6 (100 mg, $0.19 \mathrm{mmol}$ ) and selenium (150 mg, excess) and transferred to a Schlenk line. $20 \mathrm{ml}$ of THF were added and the mixture was stirred at room temperature. The progress of the oxidation was monitored via in situ ${ }^{31} \mathrm{P}$ NMR spectroscopy. After completion, excess selenium was removed via filtration and the solvent was removed in vacuo yielding $\mathbf{9}$ as an air stable white solid (130 mg, quantitative).

${ }^{1} \mathrm{H}$ NMR $\left(25{ }^{\circ} \mathrm{C}, \mathrm{CD}_{3} \mathrm{Cl}, 400 \mathrm{MHz}\right): \delta[\mathrm{ppm}]=10.67\left(\mathrm{~d},{ }^{2} \mathrm{~J}_{\mathrm{PH}}=6.3 \mathrm{~Hz}, 1 \mathrm{H}, \mathrm{H} 4\right), 9.23(\mathrm{~s}, 1 \mathrm{Hm}$ $\mathrm{H} 7), 8.56(\mathrm{~s}, 1 \mathrm{H}, \mathrm{H} 3), 8.50\left(\mathrm{~d},{ }^{3} \mathrm{~J}_{\mathrm{HH}}=8.8 \mathrm{~Hz}, 1 \mathrm{H}, \mathrm{H} 2\right), 7.93\left(\mathrm{~d},{ }^{3} \mathrm{~J}_{\mathrm{HH}}=8.5 \mathrm{~Hz}, 1 \mathrm{H}, \mathrm{H} 6\right), 7.83(\mathrm{~d}$, $\left.{ }^{3} \mathrm{~J}_{\mathrm{HH}}=8.8 \mathrm{~Hz}, 1 \mathrm{H}, \mathrm{H} 1\right), 7.83\left(\mathrm{~d},{ }^{3} \mathrm{~J}_{\mathrm{HH}}=8.5 \mathrm{~Hz}, 1 \mathrm{H}, \mathrm{H} 7\right), 6.56\left(\mathrm{~d},{ }^{2} \mathrm{~J}_{\mathrm{PH}}=15.5 \mathrm{~Hz}, 1 \mathrm{H}, \mathrm{H} 8\right), 1.59$ (s, $18 \mathrm{H}$, 'Bu). 
${ }^{31} \mathrm{P}$ NMR $\left(25^{\circ} \mathrm{C}, \mathrm{CD}_{3} \mathrm{Cl}, 202 \mathrm{MHz}\right): \delta[\mathrm{ppm}]=26.3$ (d accompanied by ${ }^{77}$ Se satellites, ${ }^{1} \mathrm{~J}_{\mathrm{PSe}}=$ $914.5 \mathrm{~Hz},{ }^{2} \mathrm{~J}_{\mathrm{PP}}=19.3 \mathrm{~Hz}$ ), 21.9 (d accompanied by ${ }^{77}$ Se satellites, ${ }^{1} \mathrm{~J}_{\mathrm{PSe}}=916.5 \mathrm{~Hz},{ }^{2} \mathrm{~J}_{\mathrm{PP}}=$ $19.0 \mathrm{~Hz})$.

Elemental analysis (\%) calcd. for 9: C 35.1, H 3.8, N 12.3; found: C 35.1, H 3.9, N 11.6.

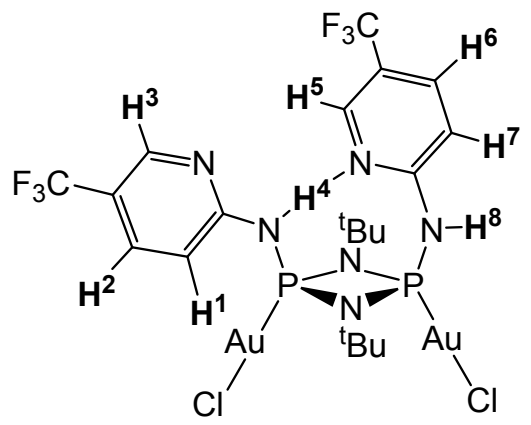

Synthesis of 10: Inside a $\mathrm{N}_{2}$ filled glovebox a Schlenk tube was charged with 6 (100 mg, $0.19 \mathrm{mmol})$ and (THT)AuCl 2 (122mg, $0.38 \mathrm{mmol})$ and transferred to a Schlenk line. $3 \mathrm{ml}$ of DCM were added and the mixture was stirred at room temperature for 10 minutes. Afterwards all volatiles were removed and the remaining white solid was washed with Pentane and dried in vacuo yielding 10 as a white powder (185 $\mathrm{mg}, 99 \%)$.

${ }^{1} \mathrm{H}$ NMR $\left(25^{\circ} \mathrm{C}, \mathrm{CDCl}_{3}, 400 \mathrm{MHz}\right): \delta[\mathrm{ppm}]=10.13\left(\mathrm{~d},{ }^{2} \mathrm{~J}_{\mathrm{PH}}=9.6 \mathrm{~Hz}, 1 \mathrm{H}, \mathrm{H} 4\right), 8.86(\mathrm{~s}, 1 \mathrm{H}, \mathrm{H} 5)$, $8.61(\mathrm{~s}, 1 \mathrm{H}, \mathrm{H} 3), 8.57\left(\mathrm{~d},{ }^{2} \mathrm{~J}_{\mathrm{PH}}=20.4 \mathrm{~Hz}, 1 \mathrm{H}, \mathrm{H} 8\right), 8.00\left(\mathrm{~d},{ }^{3} \mathrm{~J}_{\mathrm{HH}}=7.5 \mathrm{~Hz}, 1 \mathrm{H}, \mathrm{H} 3\right), 7.95\left(\mathrm{~d},{ }^{3} \mathrm{~J}_{\mathrm{HH}}\right.$ $=7.5 \mathrm{~Hz}, 1 \mathrm{H}, \mathrm{H} 7), 7.80\left(\mathrm{~d},{ }^{3} \mathrm{~J}_{\mathrm{HH}}=7.6 \mathrm{H}, 1 \mathrm{H}, \mathrm{H} 4\right), 7.23\left(\mathrm{~d},{ }^{3} \mathrm{~J}_{\mathrm{HH}}=7.5 \mathrm{~Hz}, 1 \mathrm{H}, \mathrm{H} 6\right), 1.56(\mathrm{~s}, 18 \mathrm{H}$, tBu)

${ }^{31} \mathrm{P}$ NMR $\left(25^{\circ} \mathrm{C}, \mathrm{CDCl}_{3}, 202 \mathrm{MHz}\right): \delta[\mathrm{ppm}]=80.5\left(\mathrm{~d}, \mathrm{~J}_{\mathrm{PP}}=15 \mathrm{~Hz}\right), 68.1\left(\mathrm{~d}, \mathrm{~J}_{\mathrm{PP}}=15 \mathrm{~Hz}\right)$

Elemental analysis (\%) calcd. for 10: C 24.2, H 2.6, N 8.4; found: C 24.9, H 2.8, N 7.7. 


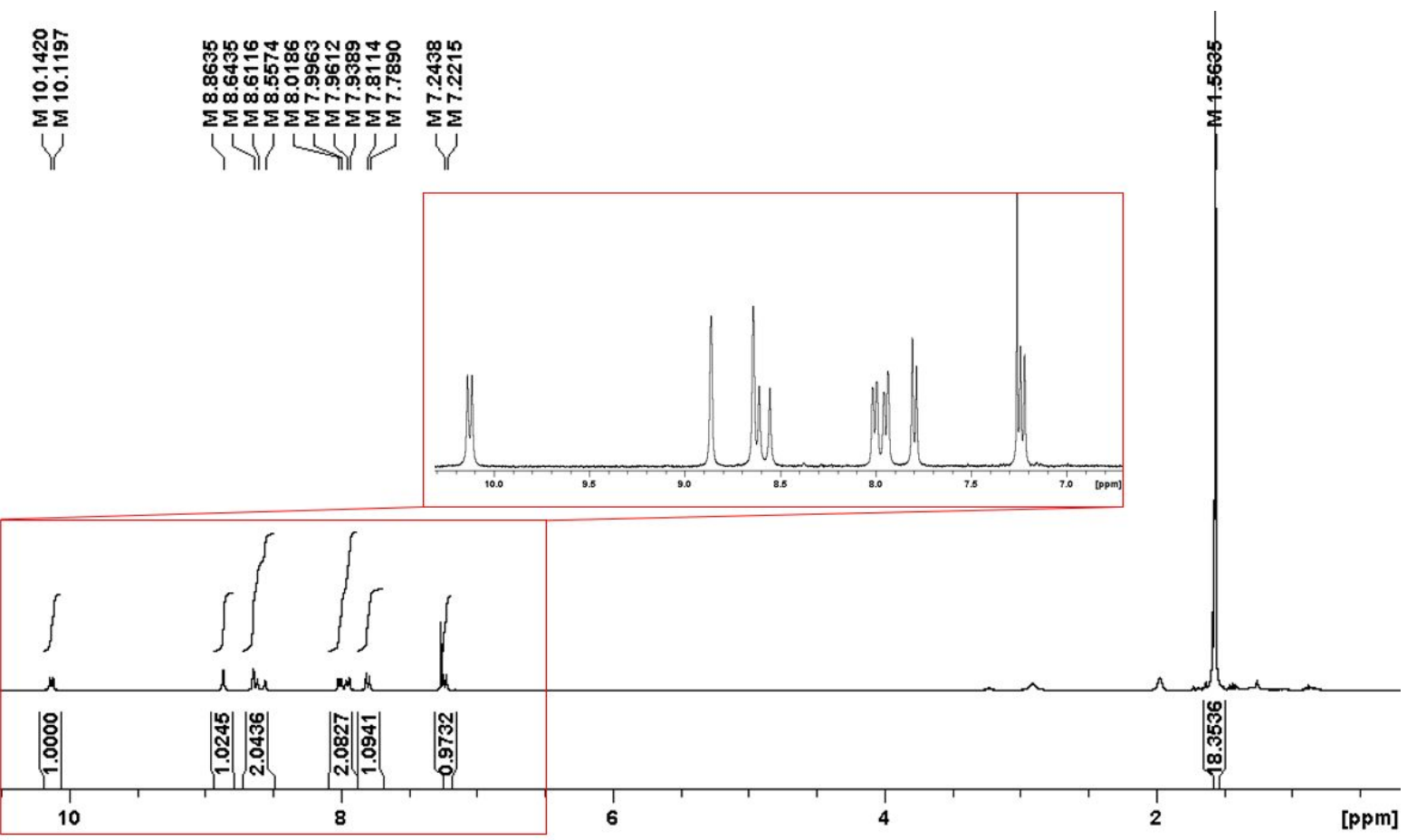

Figure S 19: ${ }^{1} \mathrm{H}$ NMR spectrum $\left(25^{\circ} \mathrm{C}, \mathrm{CDCl}_{3}, 500 \mathrm{MHz}\right)$ of 10

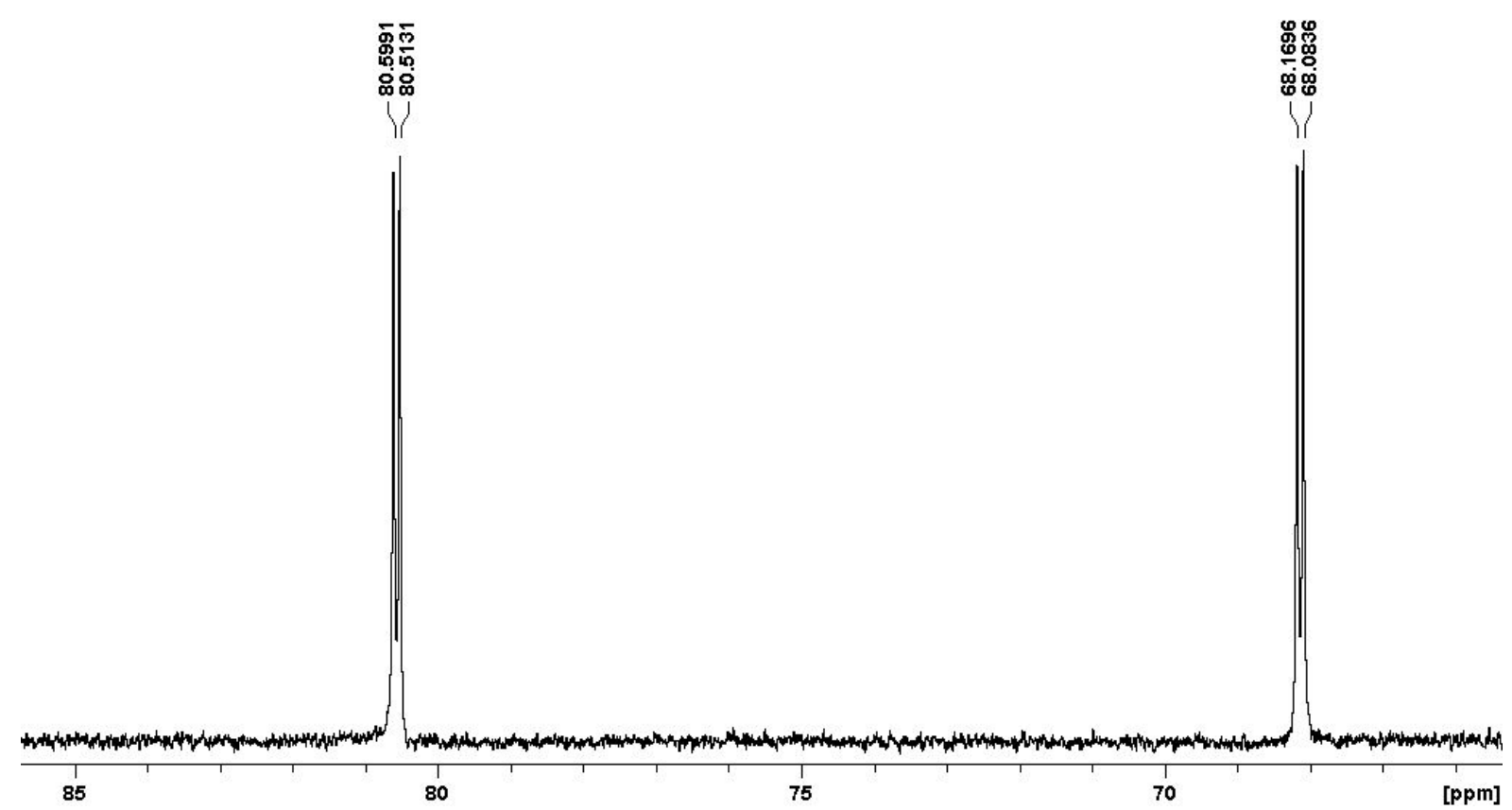

Figure S 20: ${ }^{31} \mathrm{P}$ NMR spectrum $\left(25^{\circ} \mathrm{C}, \mathrm{CDCl}_{3}, 202 \mathrm{MHz}\right)$ of 10 


\section{Binding Studies}

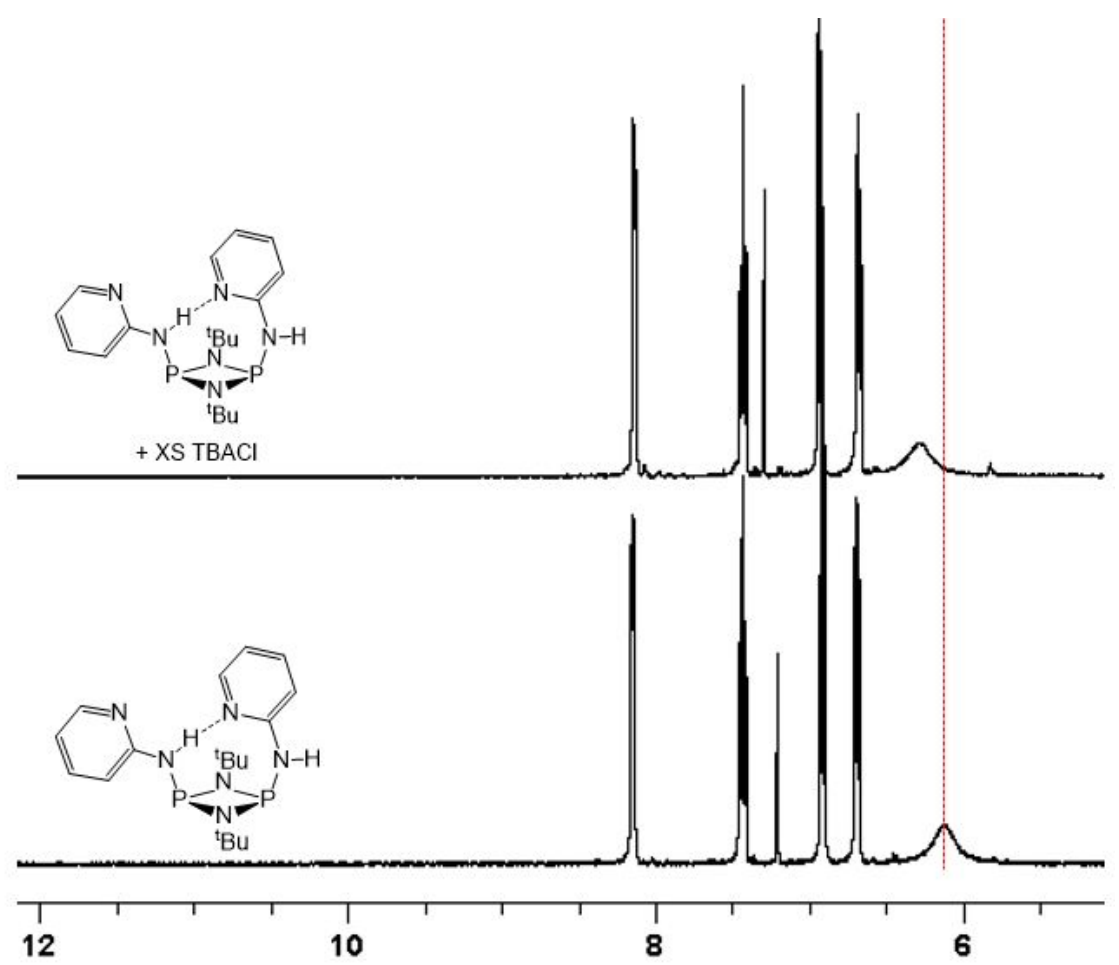

Figure S 21: ${ }^{1} \mathrm{H}$ NMR spectrum $\left(25^{\circ} \mathrm{C}, \mathrm{CDCl}_{3}, 500 \mathrm{MHz}\right)$ of 1 before and after the addition of approximately 10 equivalents of $\mathrm{TBACl}$; spectra were referenced to residual grease as chloroform peak was observe to shift due to adding residual water in $\mathrm{TBACl}$ to dry $\mathrm{CDCl}_{3}$ solution; although addition of 10 equivalents caused minimal shifting (approximately $0.1 \mathrm{ppm}$ ) we were unable to obtained suitable fits to a 1:1 or 2:1 binding model, hence we assume binding with $\mathrm{K}_{\mathrm{A}}>5 \mathrm{M}^{-1}$.

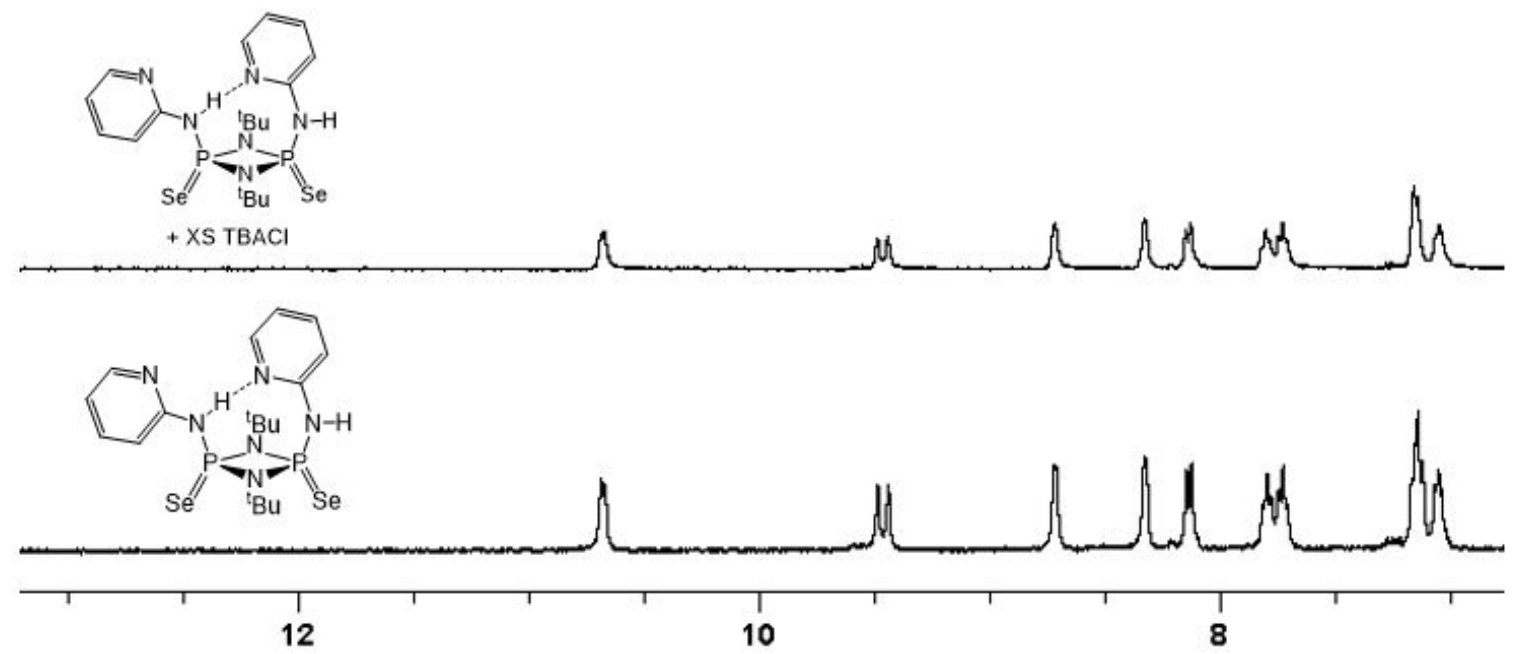

Figure S 22: ${ }^{1} \mathrm{H}$ NMR spectrum $\left(25^{\circ} \mathrm{C}, \mathrm{d}_{6}\right.$-DMSO, $\left.500 \mathrm{MHz}\right)$ of 2 before and after the addition of approximately 10 equivalents of $\mathrm{TBACl}$; behaviour in $\mathrm{CDCl}_{3}$ is analogous. 


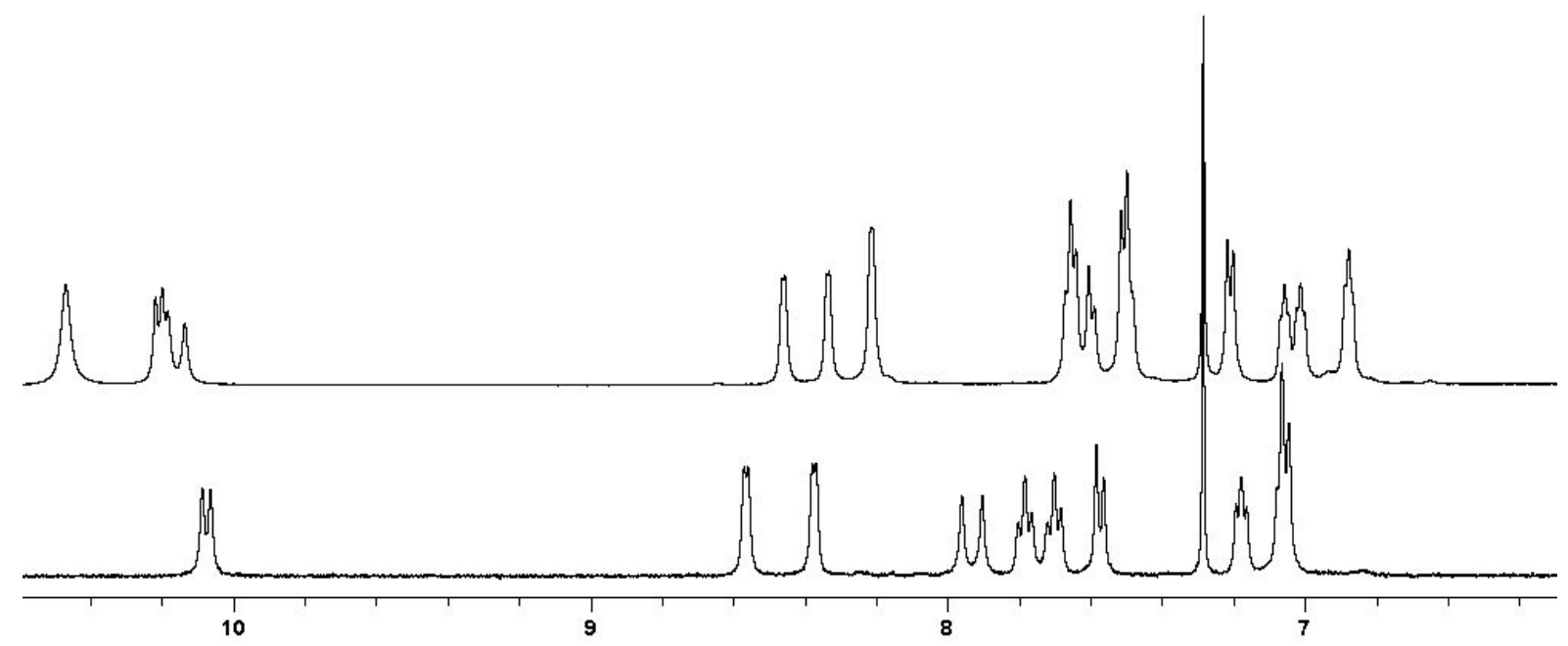

Figure S 23: Overlaid ${ }^{1} \mathrm{H}$ NMR spectra $\left(25^{\circ} \mathrm{C}, \mathrm{CDCl}_{3}, 400 \mathrm{MHz}\right)$ of 3 (bottom) before and (top) after the addition of $1.5 \mathrm{eq}$ TBACl.
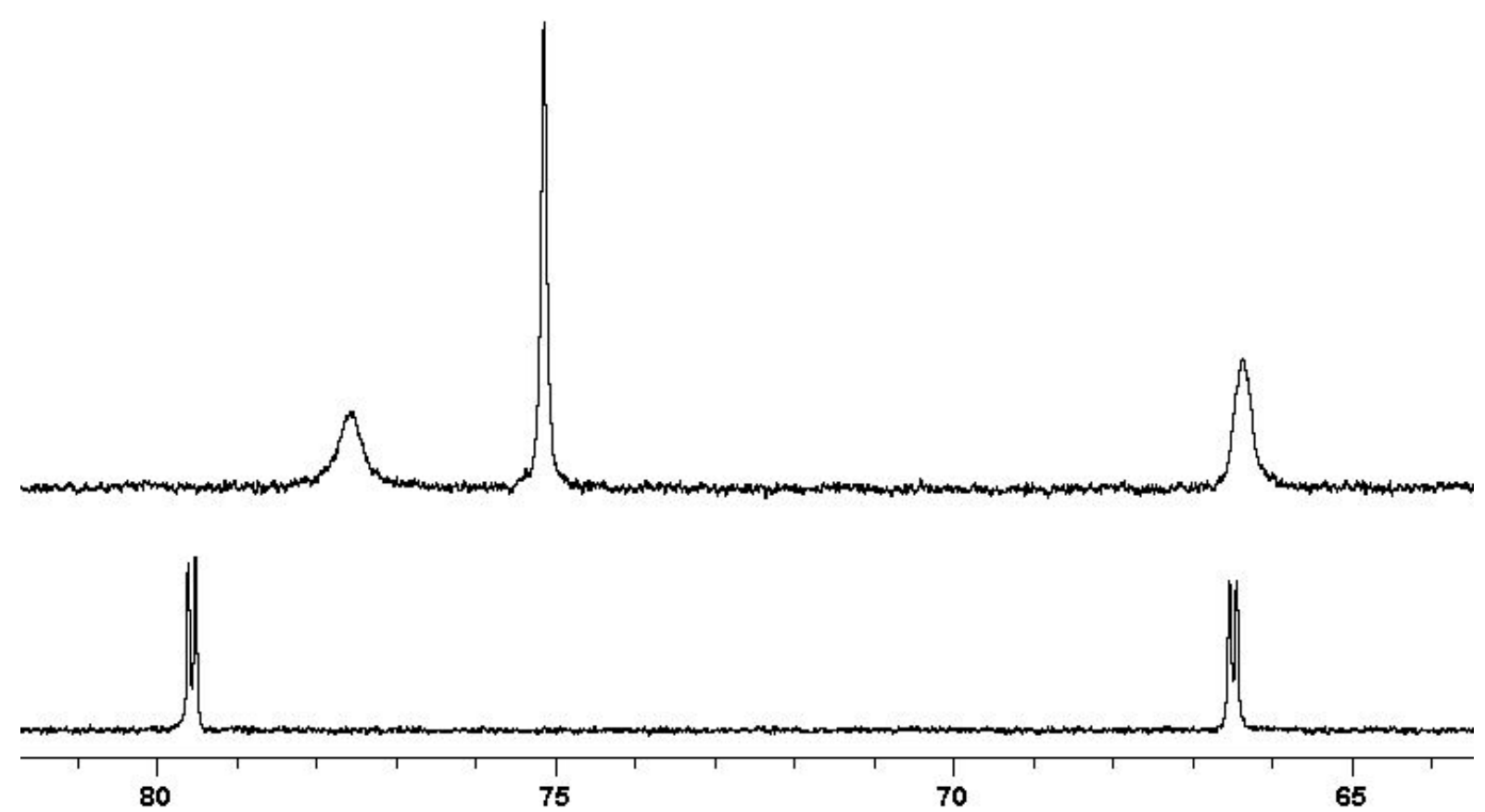

Figure S 24: Overlaid ${ }^{31} \mathrm{H}$ NMR spectra $\left(25^{\circ} \mathrm{C}, \mathrm{CDCl}_{3}, 202 \mathrm{MHz}\right)$ of 3 (bottom) before and (top) after the addition of $1.5 \mathrm{eq}$ TBACl. 


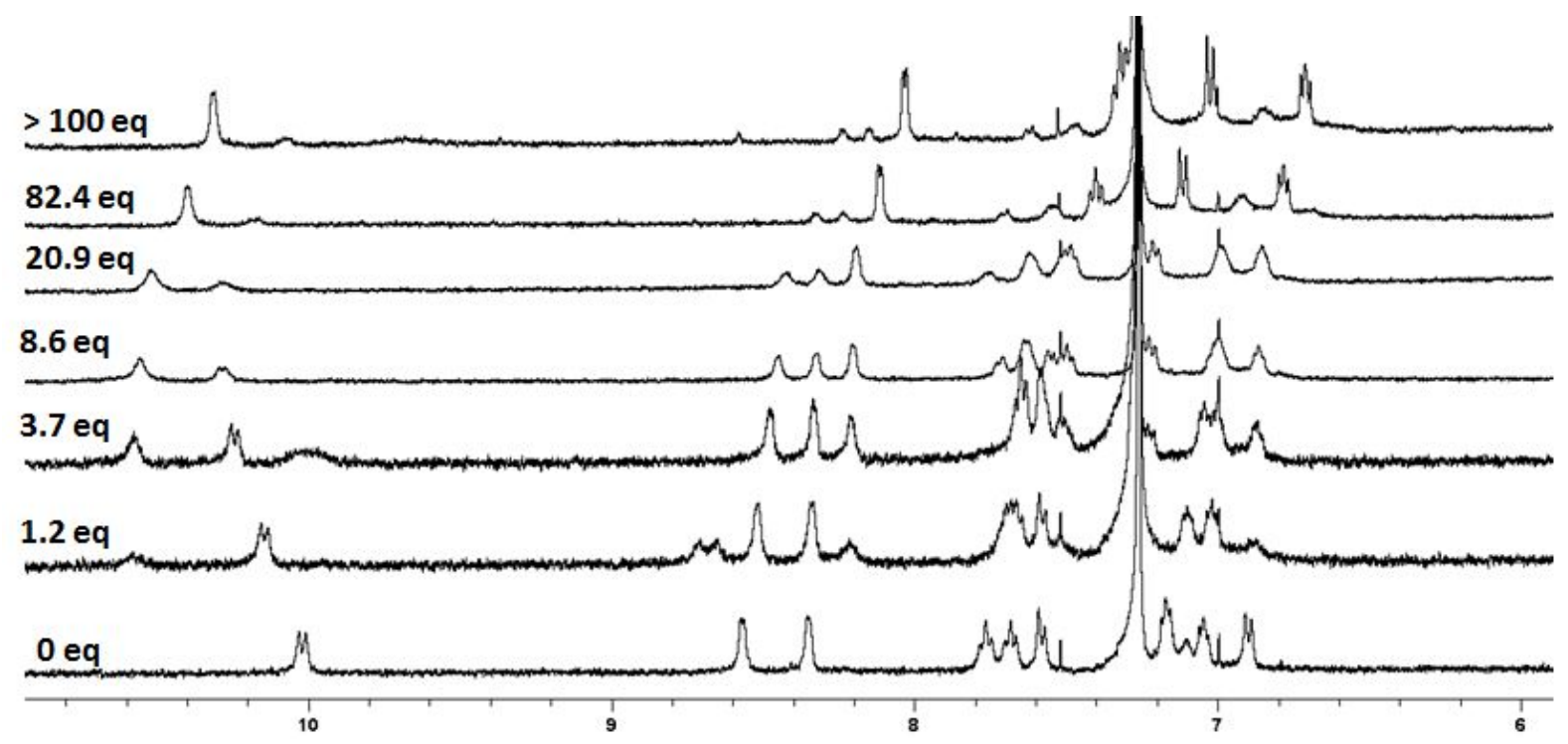

Figure S 25: ${ }^{1} \mathrm{H}$ NMR titration $\left(25^{\circ} \mathrm{C}, \mathrm{CDCl}_{3}, 400 \mathrm{MHz}\right)$ of 3 with increasing amounts of tetrabutyl ammoniumchloride. We were unable to fit this data, which we attribute to other processes occurring such as side-on binding and interaction with tetrabutylammonium. Also integration proved unreliable due to the large amount of $\mathrm{TABCI}$ required. Hence, we estimated the binding constant by the guest concentration at the half-way saturation value.

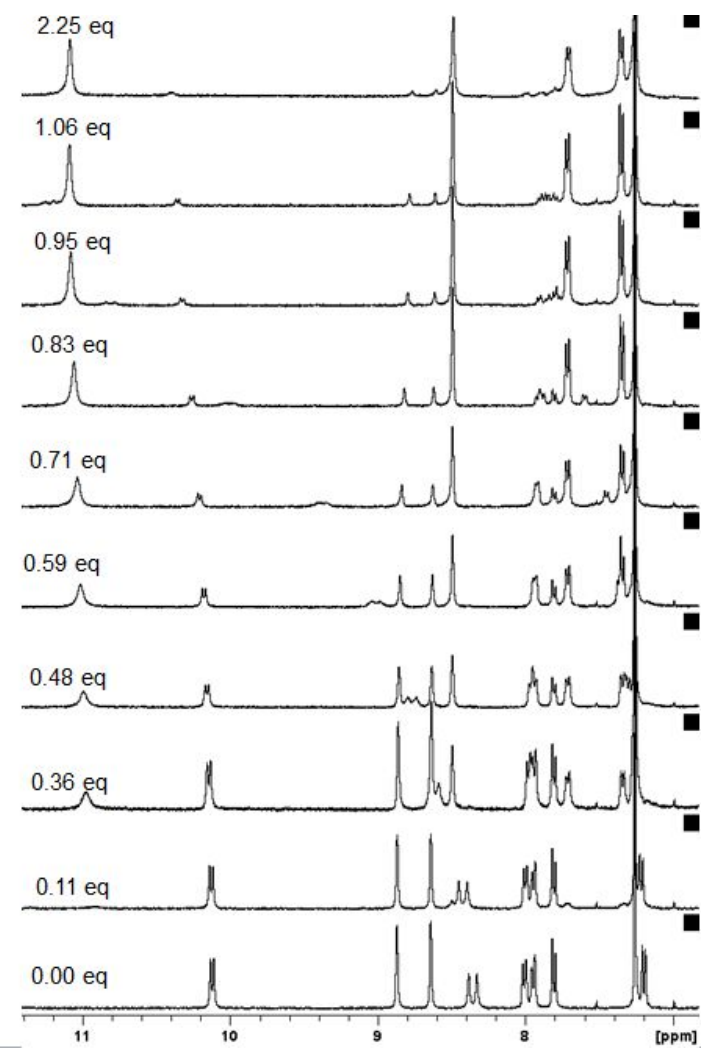

Figure S 26: ${ }^{1} \mathrm{H}$ NMR titration $\left(25^{\circ} \mathrm{C}, \mathrm{CDCl}_{3}, 400 \mathrm{MHz}\right)$ of 10 with increasing amounts of tetrabutylammoniumchloride. We were unable to fit this data, which we attribute to another processes occurring such as side-on binding and interaction with tetrabutylammonium. Also integration proved unreliable due to the large amount of $T A B C I$ required. Hence, we estimated the binding constant by the guest concentration at the half-way saturation value. 


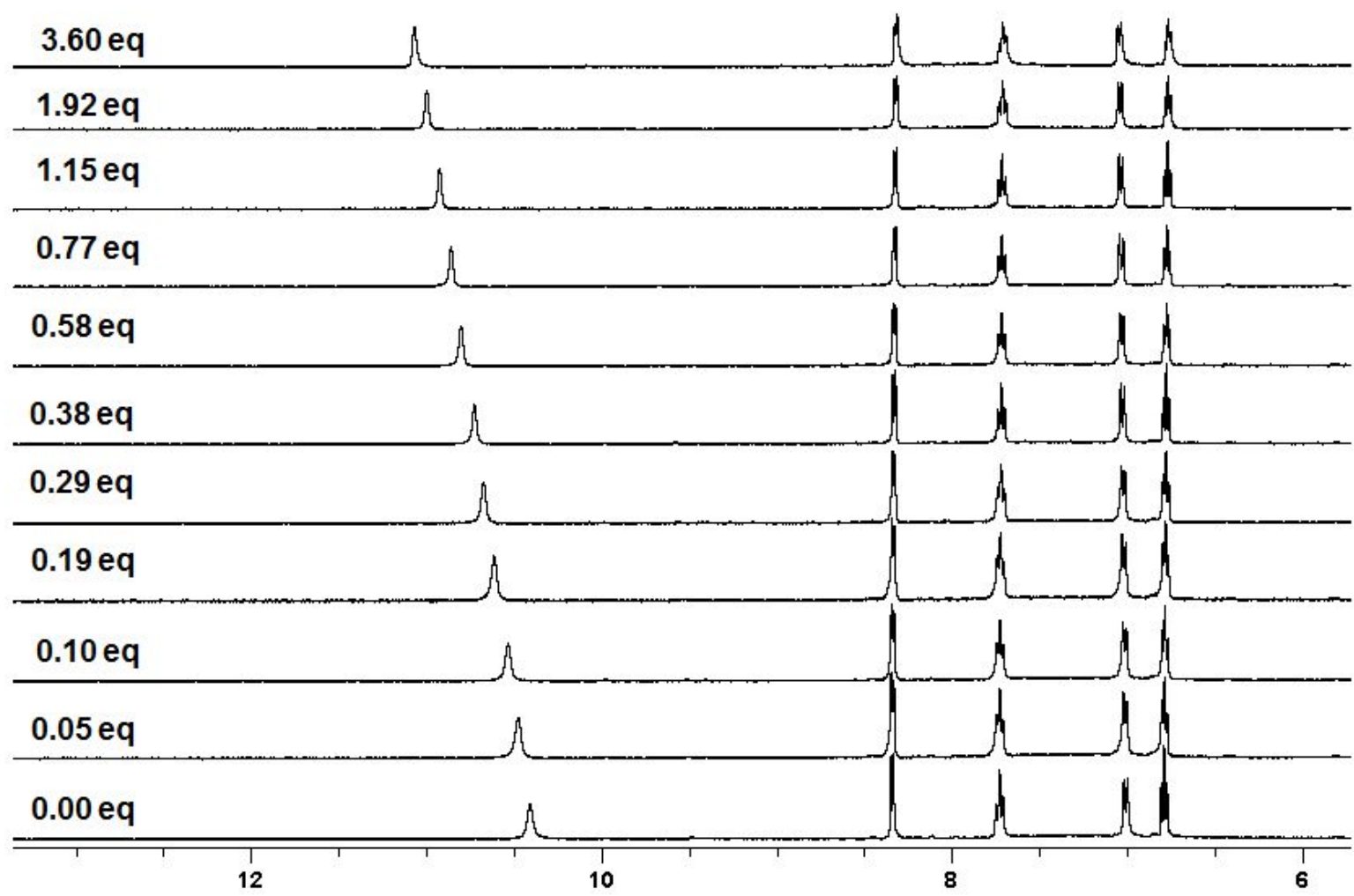

Figure S 27: ${ }^{1} \mathrm{H}$ NMR titration $\left(25^{\circ} \mathrm{C}, \mathrm{d}_{6}\right.$-DMSO, $\left.400 \mathrm{MHz}\right)$ of 4 with increasing amounts of tetrabutylammonium chloride
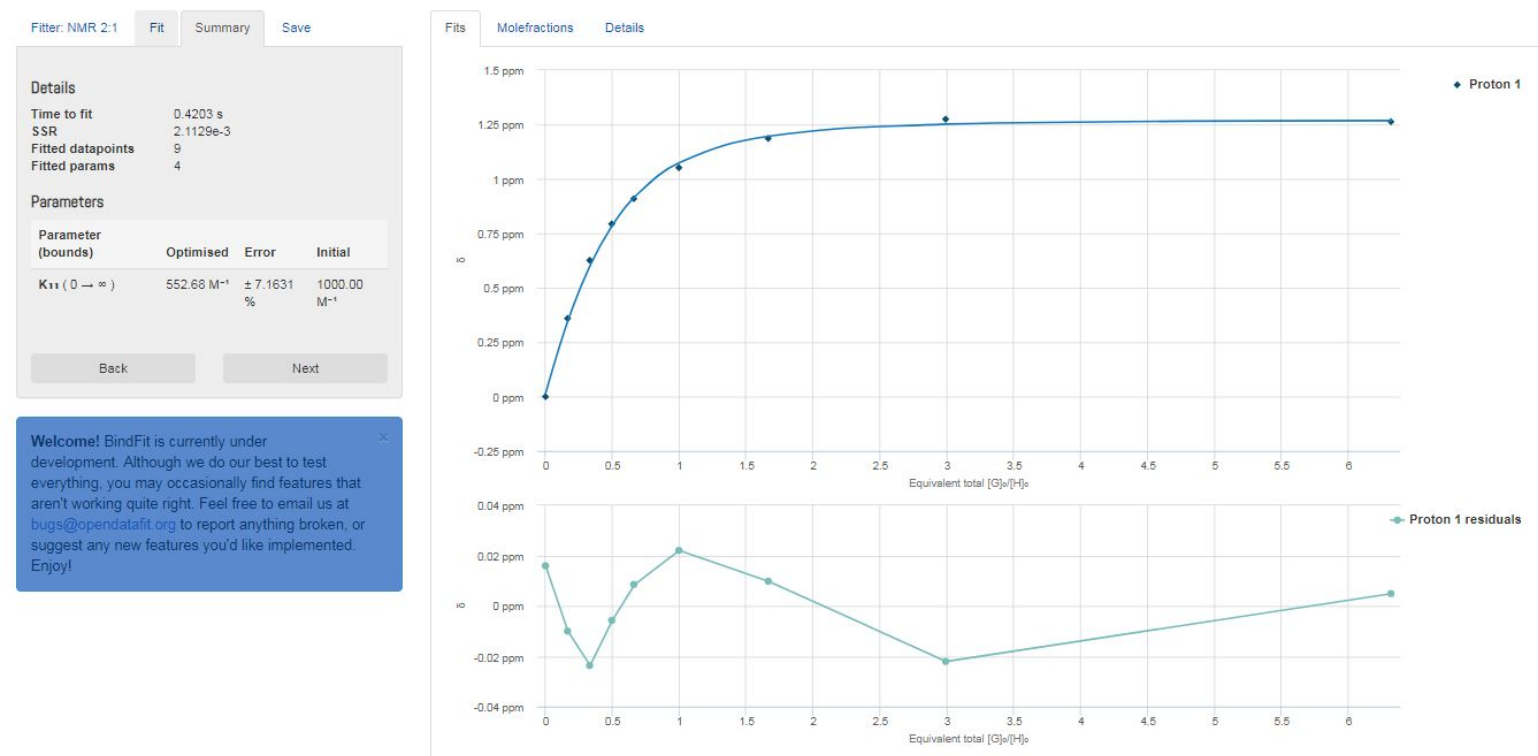

Figure S 28: Fit to a 2:1 non-cooperative binding model using the Bindfit program suite. 

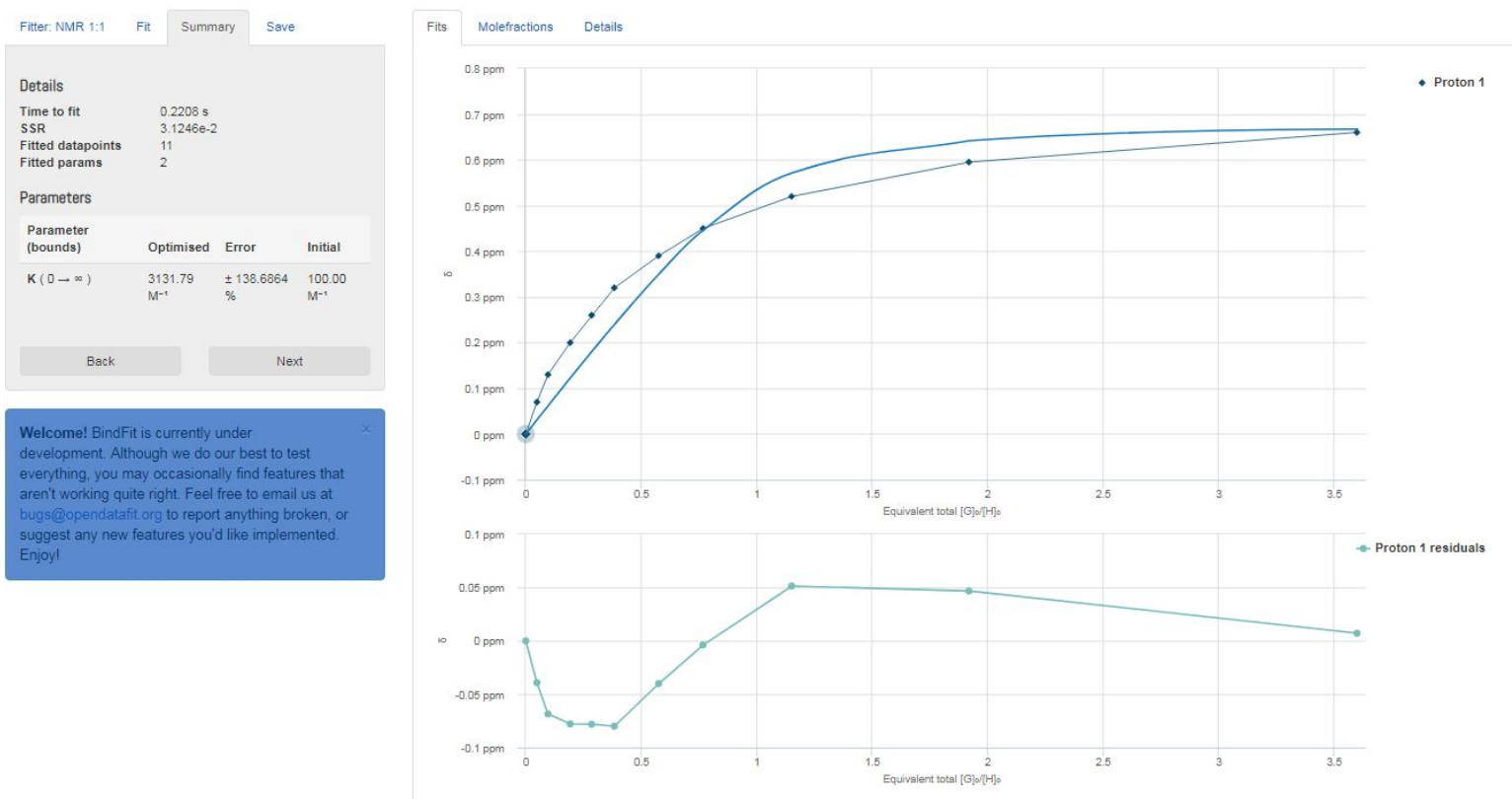

Figure S 29: Fit to a 1:1 binding model using the Bindfit program suite.
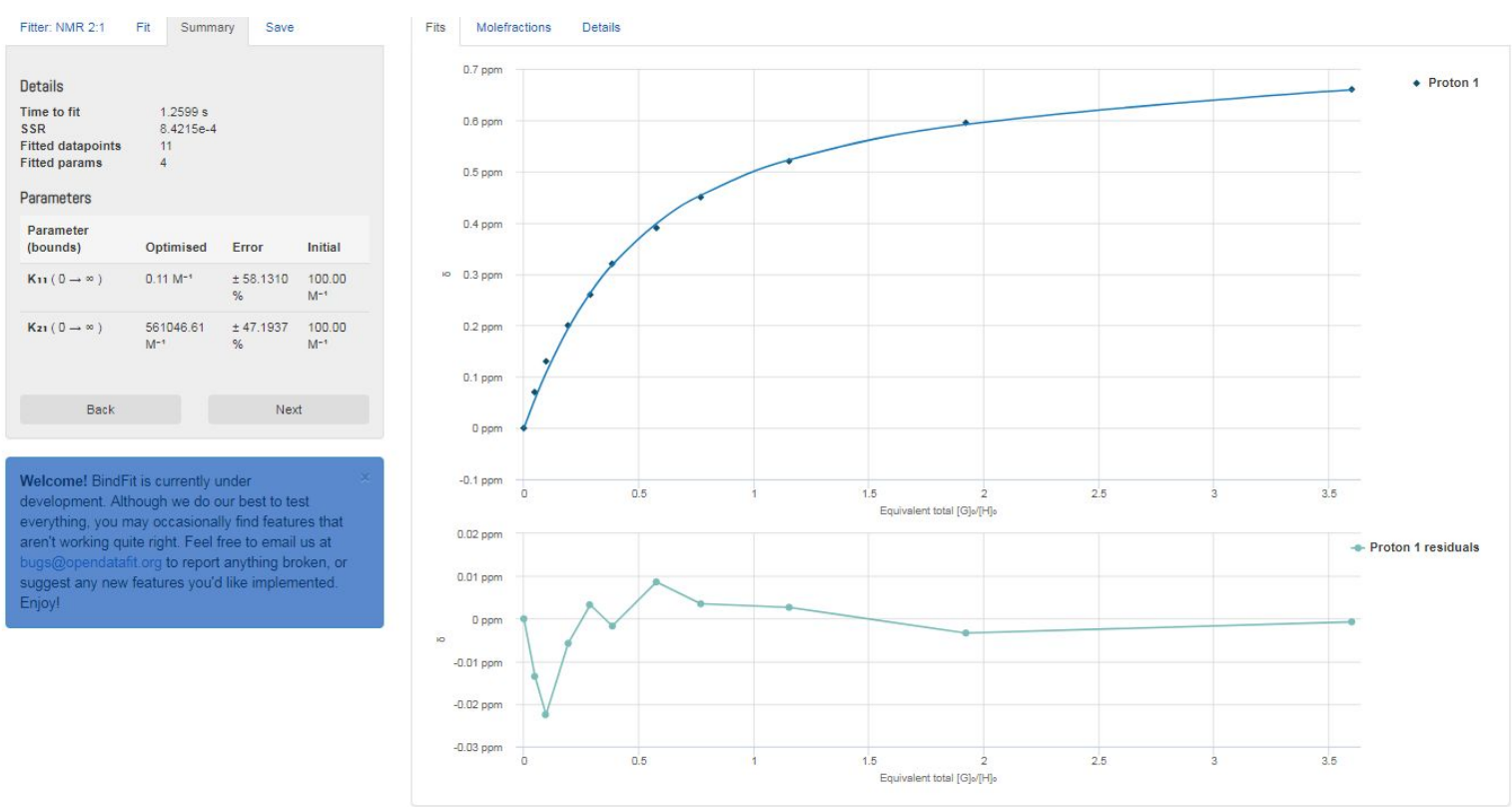

Figure S 30: Fit to a 2:1 non-cooperative binding model using the Bindfit program suite. 


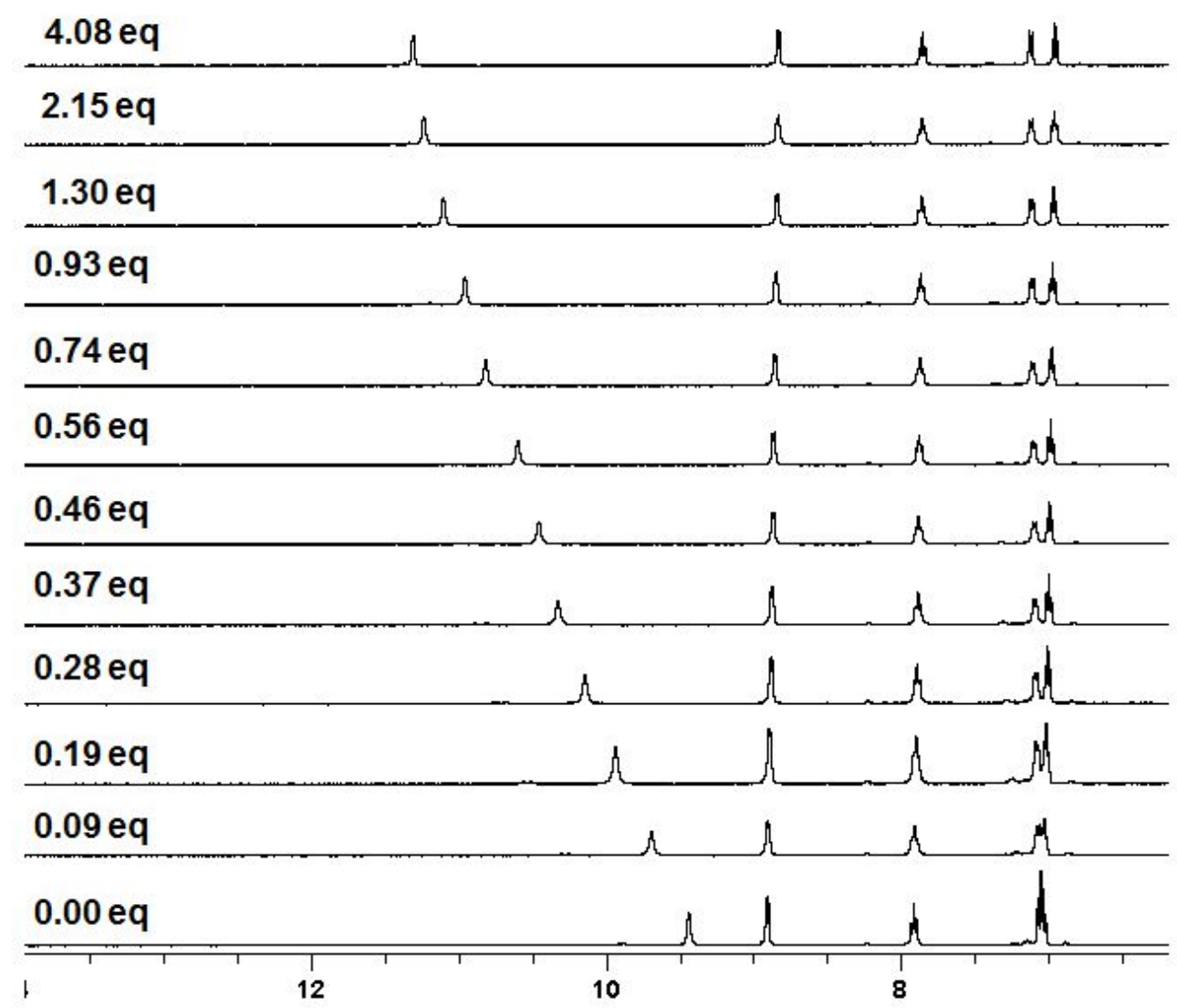

Figure S 31: ${ }^{1} \mathrm{H}$ NMR titration $\left(25^{\circ} \mathrm{C}, \mathrm{d}_{6}\right.$-DMSO, $\left.400 \mathrm{MHz}\right)$ of 5 with increasing amounts of tetrabutylammonium chloride
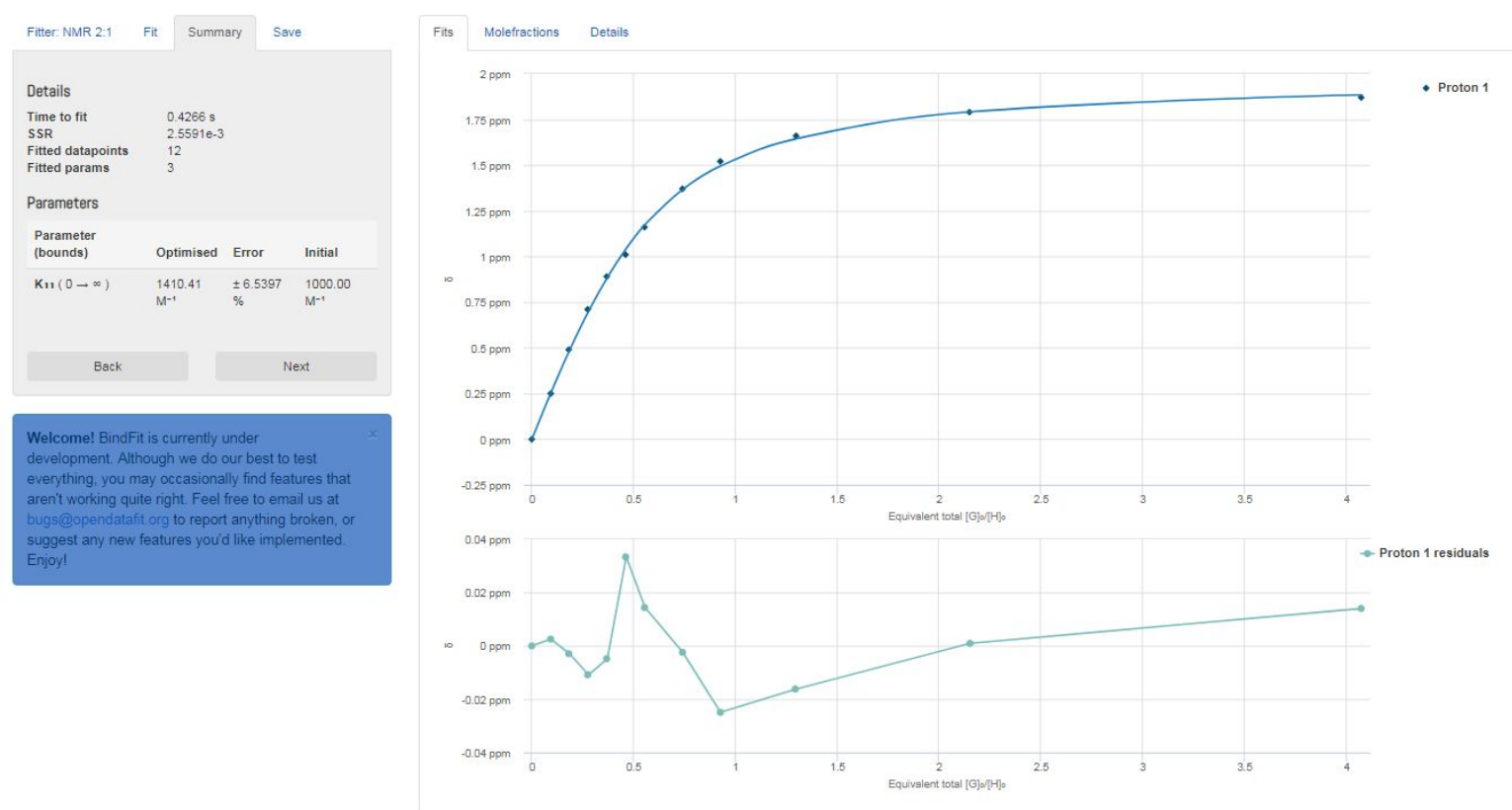

Figure S 32: Fit to a 2:1 non-cooperative binding model using the Bindfit program suite; fit to a cooperative model failed 

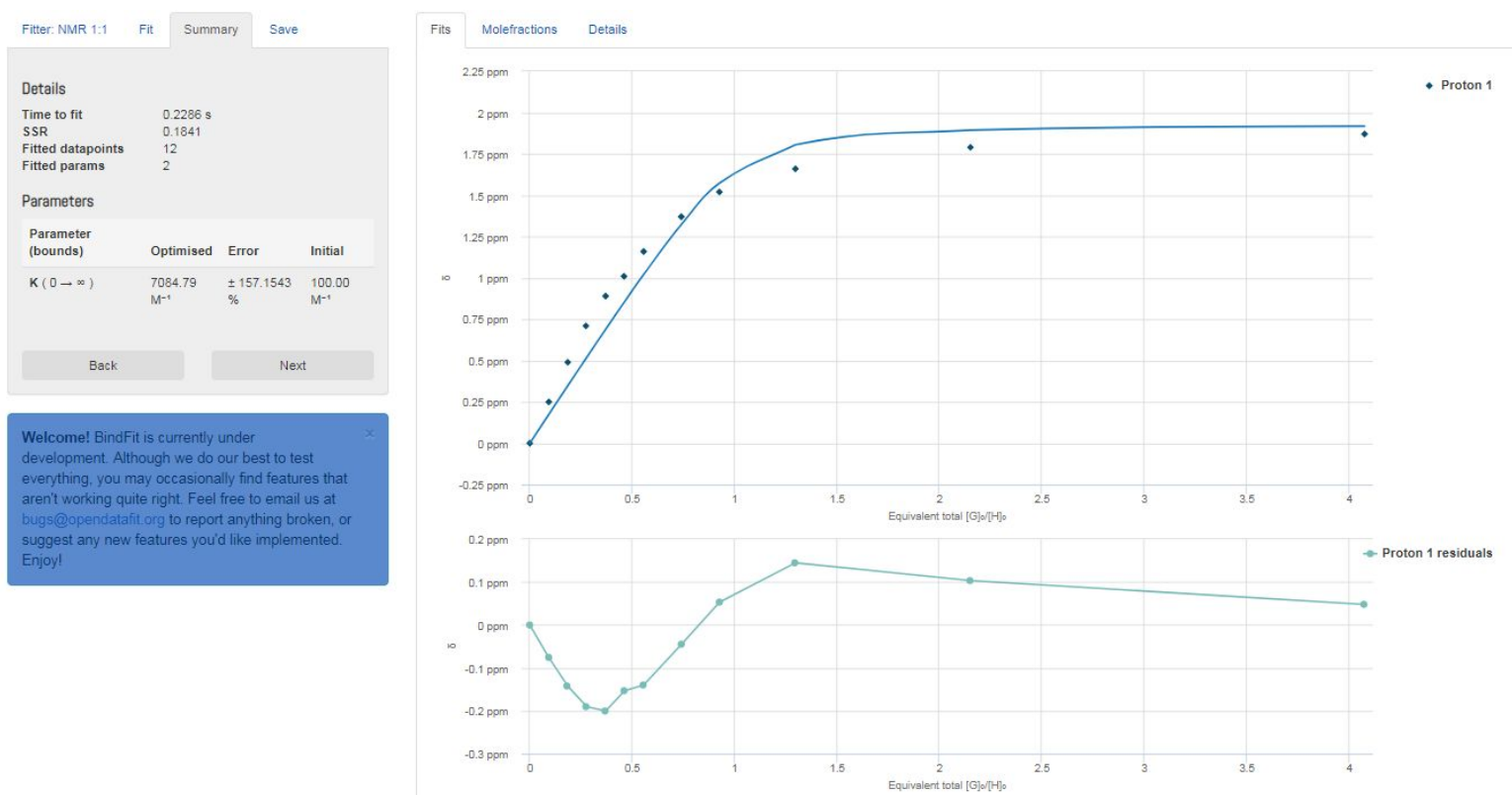

Figure S 33: Fit to a 1:1 binding model using the Bindfit program suite.

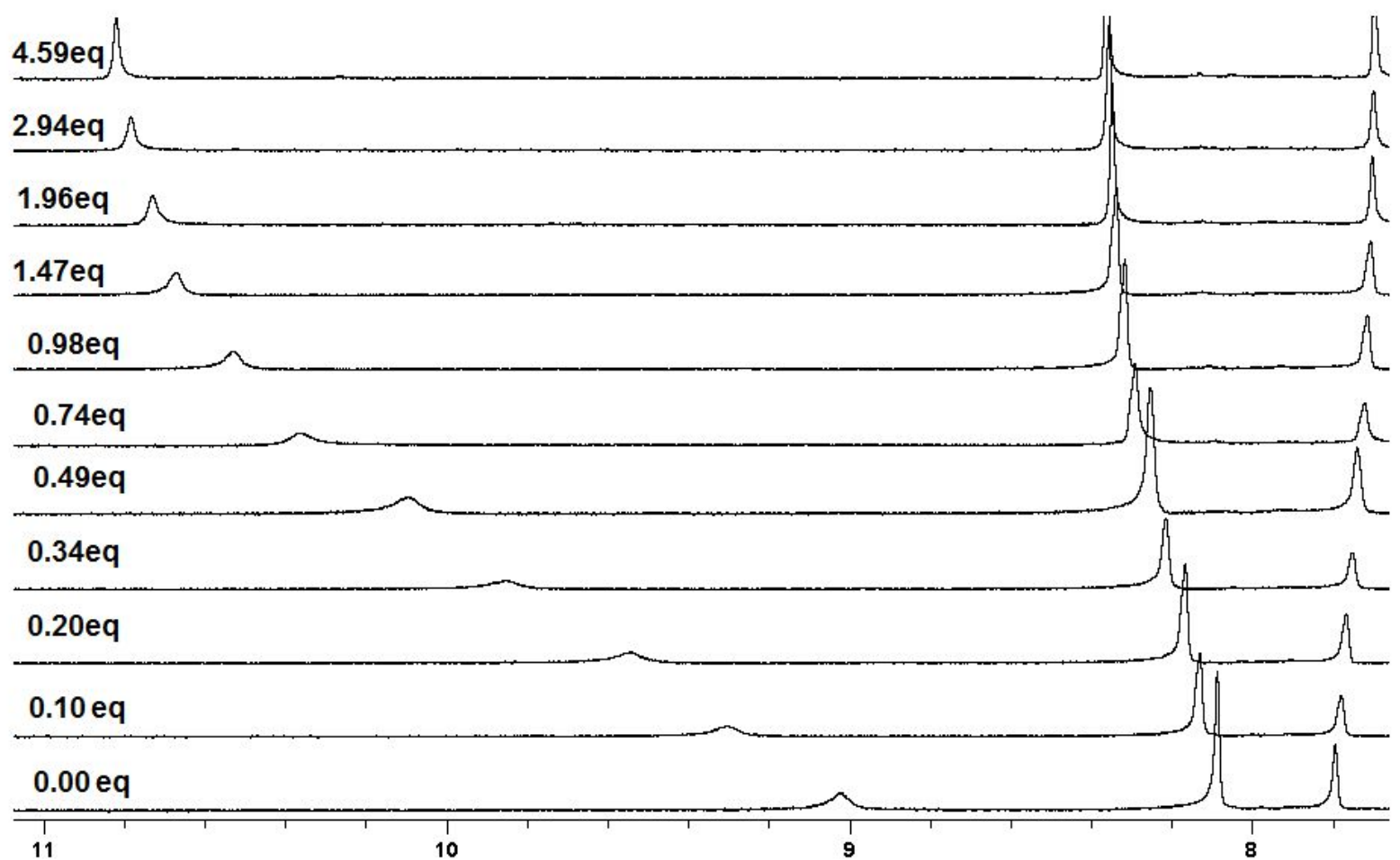

Figure S 34: ${ }^{1} \mathrm{H}$ NMR titration $\left(25^{\circ} \mathrm{C}, \mathrm{d}_{6}\right.$-DMSO, $\left.400 \mathrm{MHz}\right)$ of 8 with increasing amounts of tetrabutylammonium chloride 

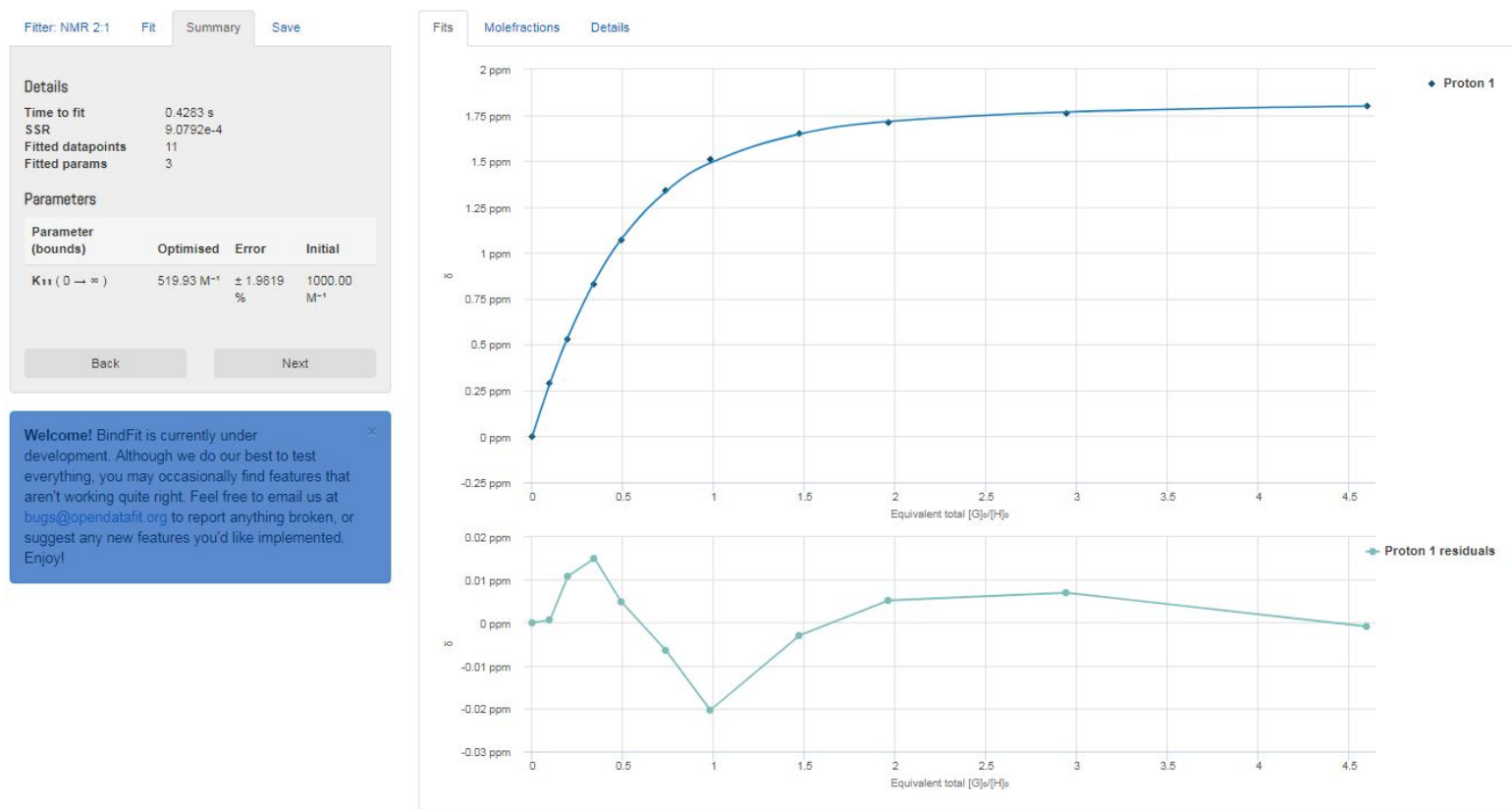

Figure S 35: Fit to a 2:1 non-cooperative binding model using the Bindfit program suite; fit to a cooperative model failed
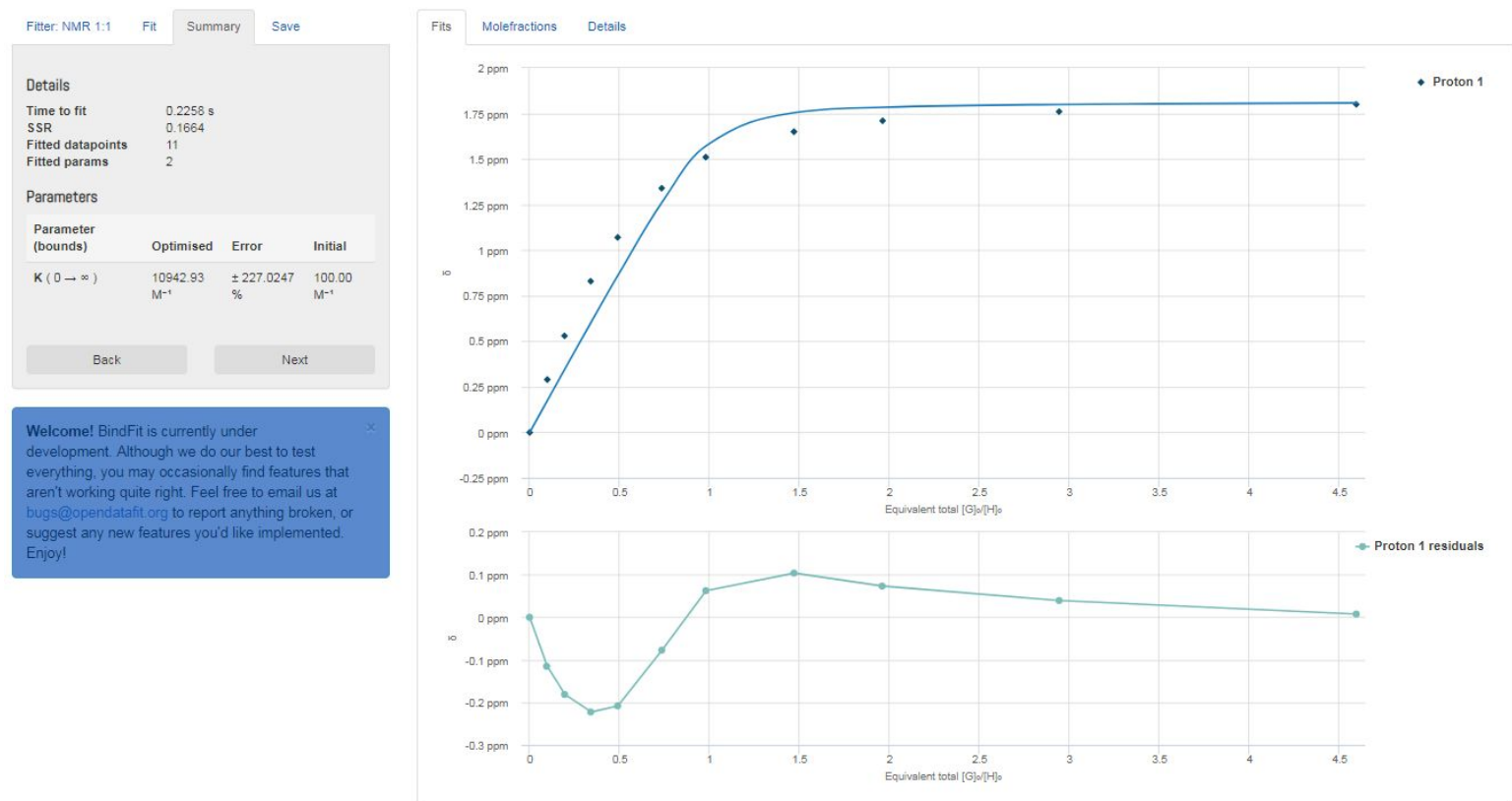

Figure S 36: Fit to a 1:1 binding model using the Bindfit program suite 


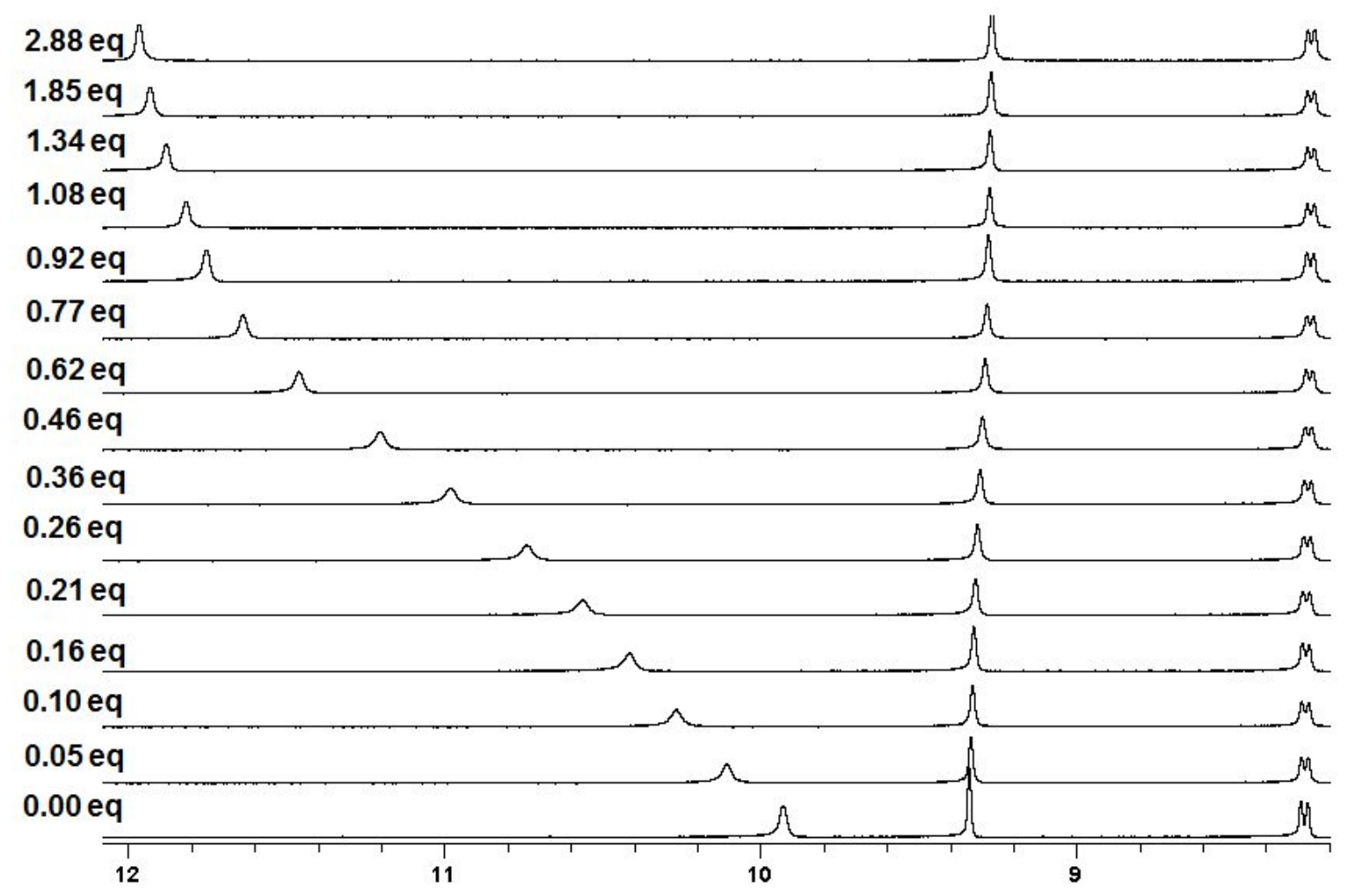

Figure S 37: ${ }^{1} \mathrm{H}$ NMR titration $\left(25^{\circ} \mathrm{C}, \mathrm{d}_{6}\right.$-DMSO, $\left.400 \mathrm{MHz}\right)$ of 7 with increasing amounts of tetrabutylammonium chloride
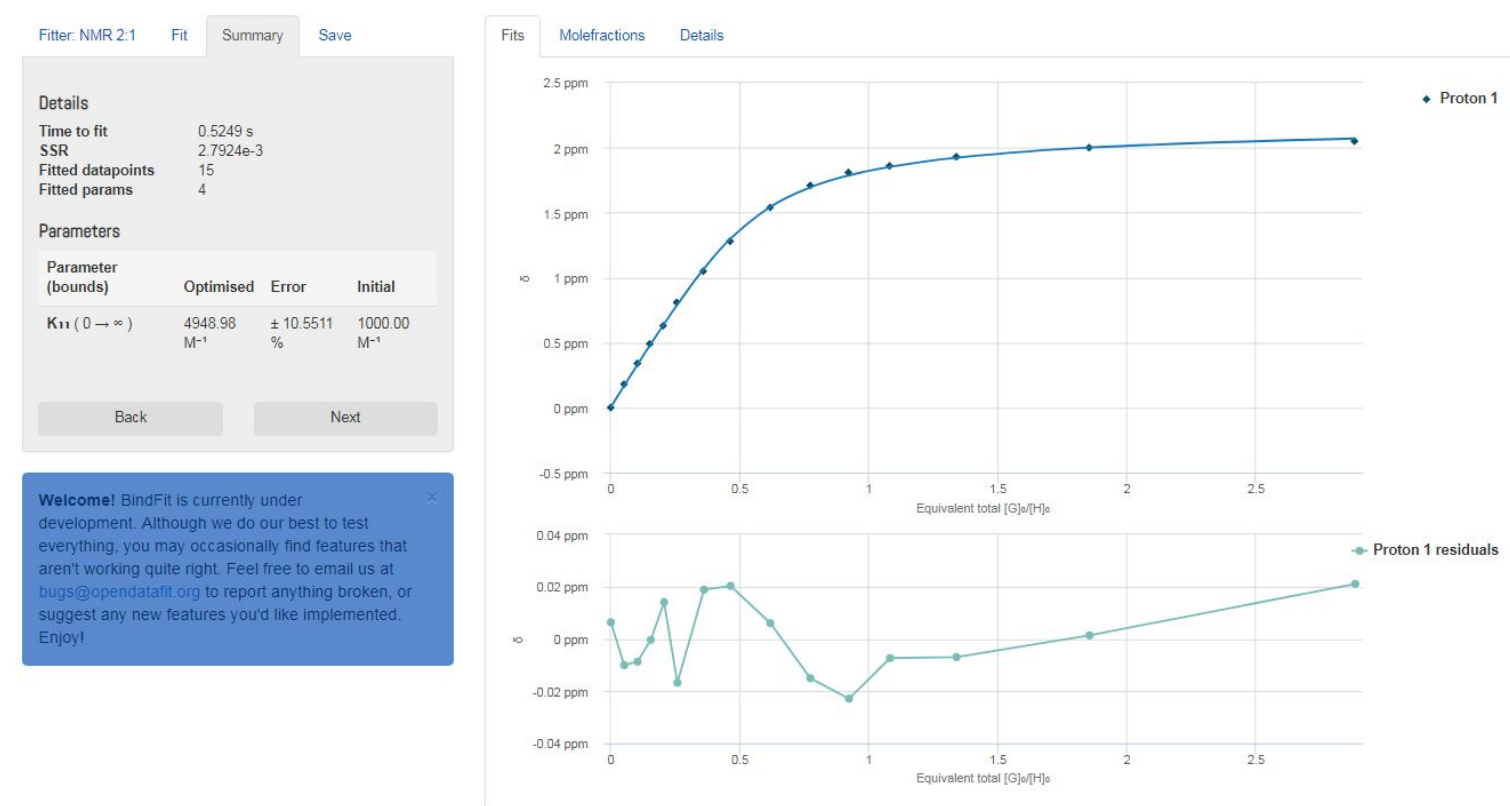

Figure S 38: Fit to a 2:1 non-cooperative binding model using the Bindfit program suite; fit to a cooperative model failed 

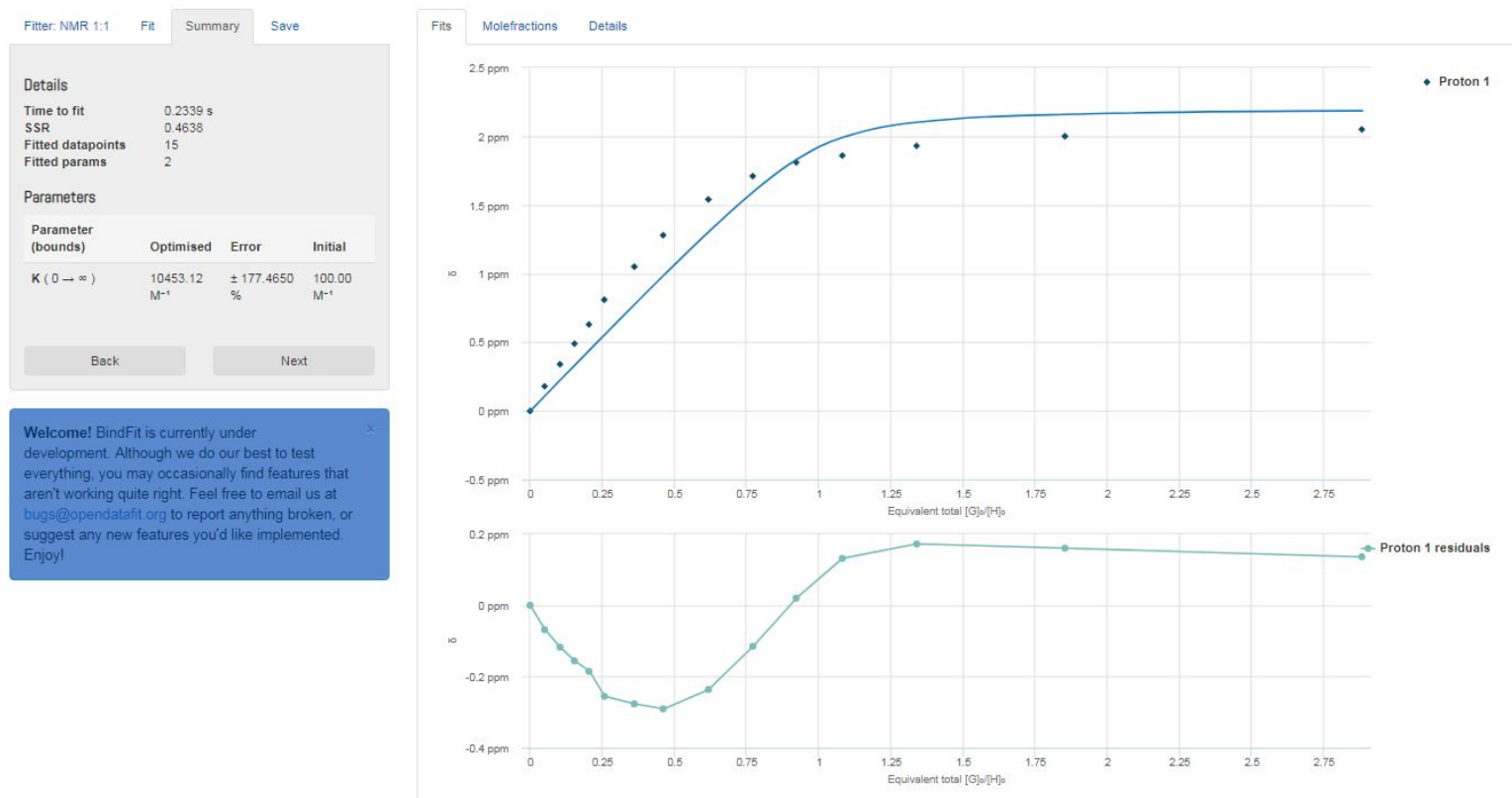

Figure S 39: Fit to a 1:1 binding model using the Bindfit program suite

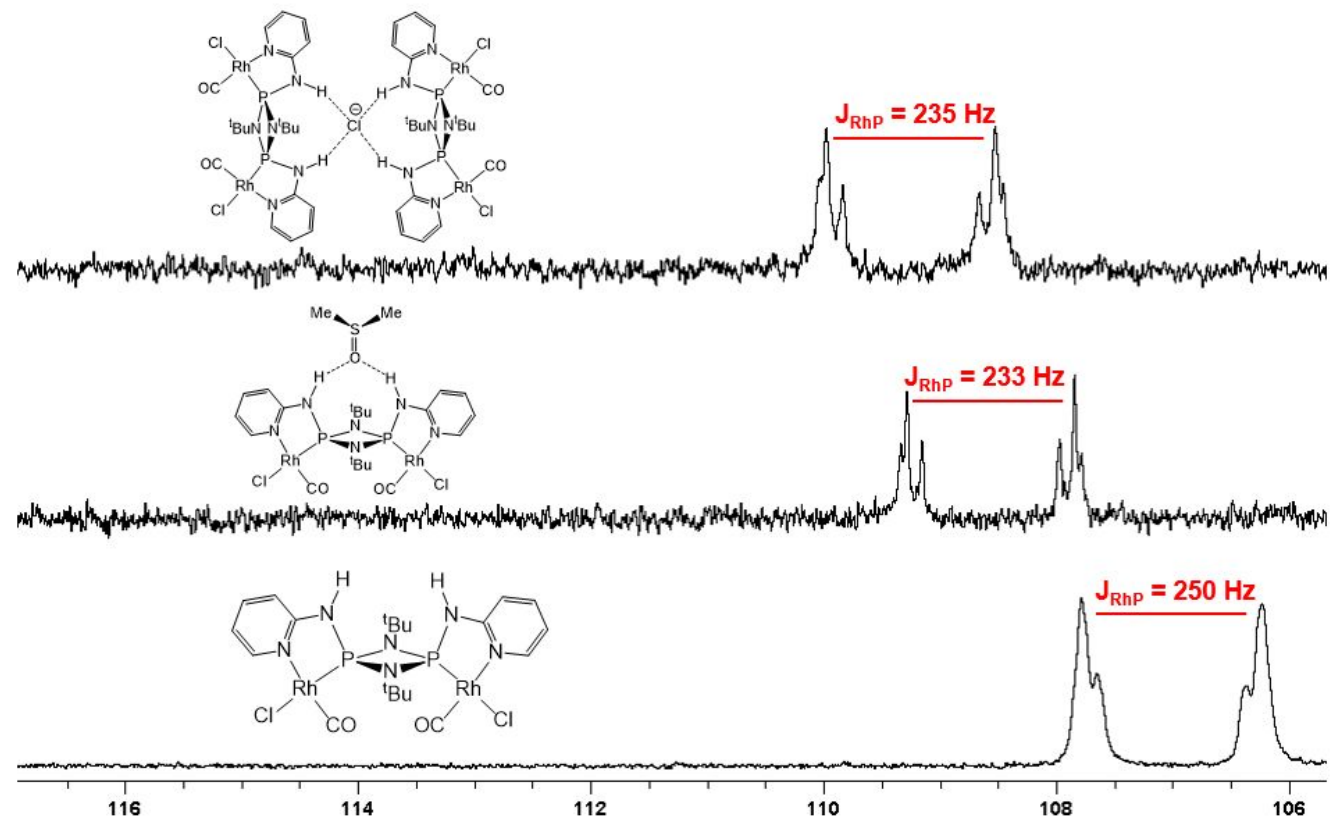

Figure S 40: Overlaid ${ }^{31} \mathrm{P}\left(25^{\circ} \mathrm{C}, 202 \mathrm{MHz}\right) \mathrm{NMR}$ spectra of (bottom) 5 in $\mathrm{CD}_{2} \mathrm{Cl}_{2}$, (middle) 5 in $\mathrm{d}_{6}$-DMSO, (top) 5 in $\mathrm{CD}_{2} \mathrm{Cl}_{2}$ in the presence of ca 10 equivalents TBACl. 

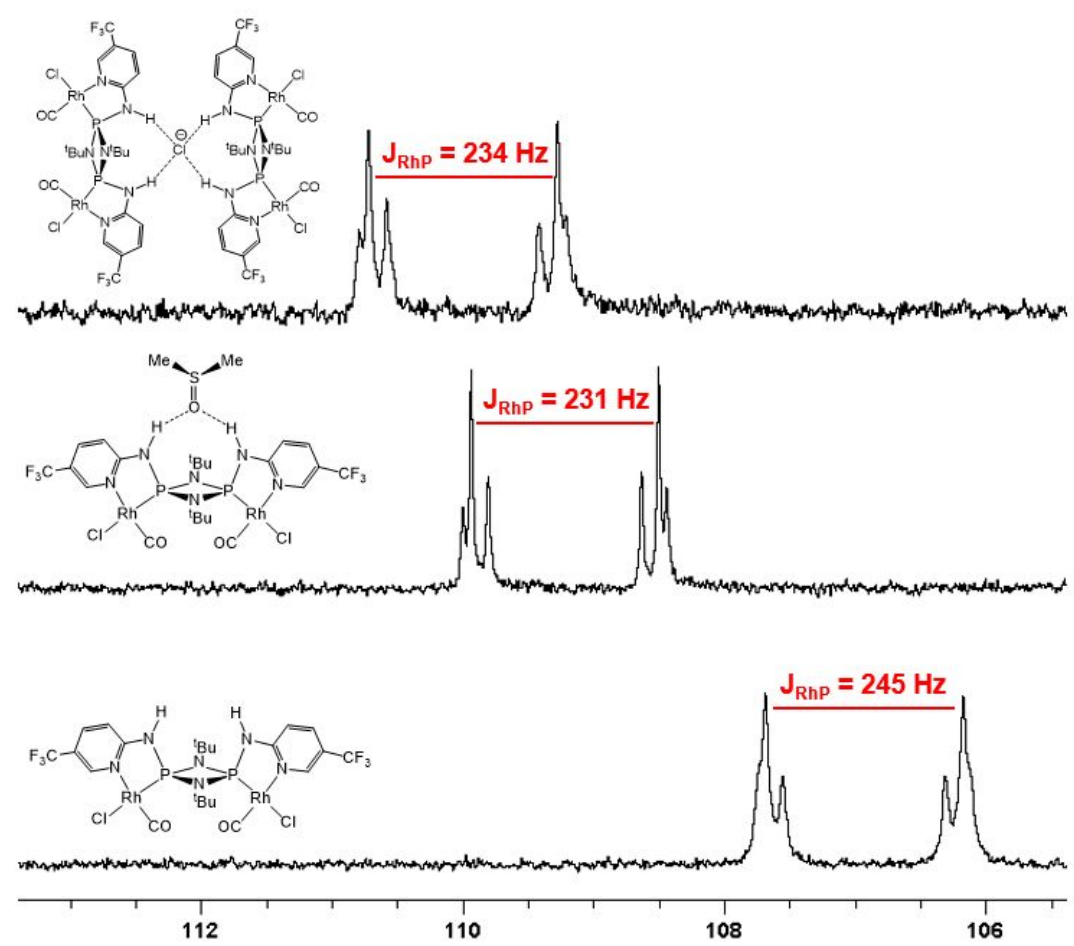

Figure S 41: Overlaid ${ }^{31} \mathrm{P}\left(25^{\circ} \mathrm{C}, 202 \mathrm{MHz}\right)$ NMR spectra of (bottom) 7 in $\mathrm{CD}_{2} \mathrm{Cl}_{2}$, (middle) 7 in $\mathrm{d}_{6}$-DMSO, (top) 7 in $\mathrm{CD}_{2} \mathrm{Cl}_{2}$ in the presence of ca 10 equivalents TBACl.
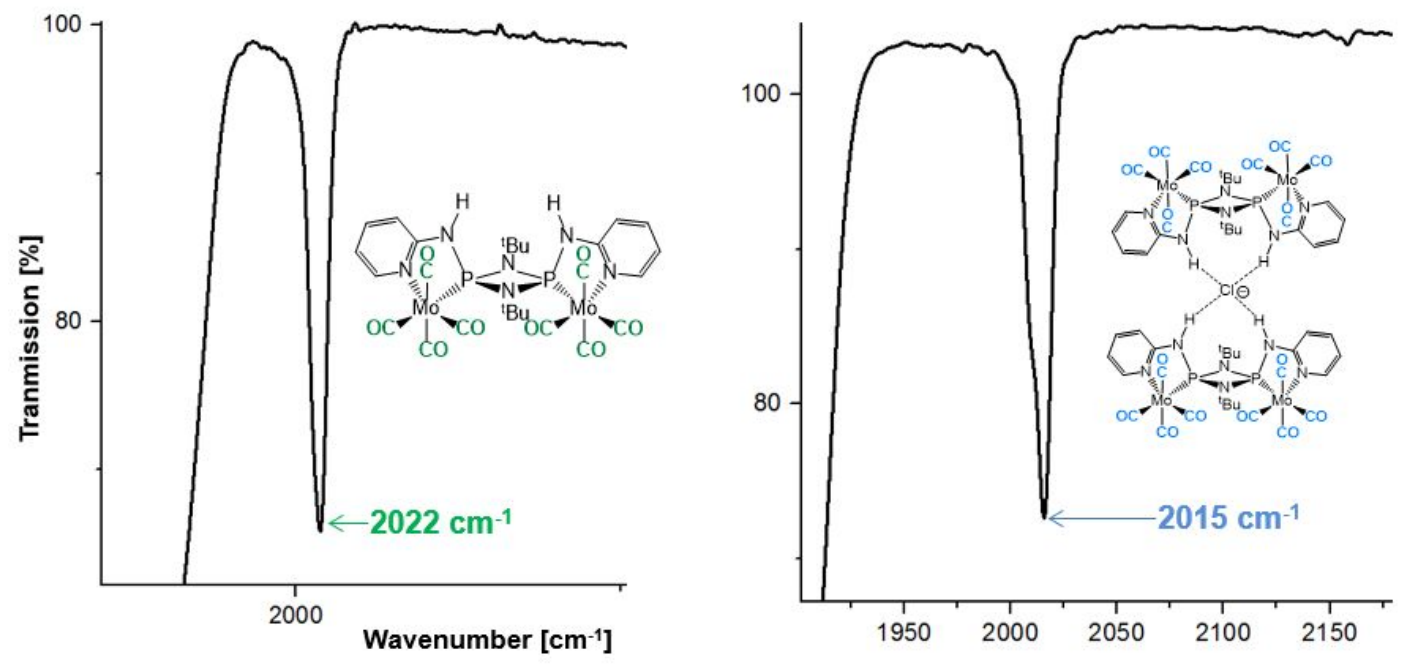

Figure S 42: Solid-state ATIR of 4 before and after addition of TBACl; for collection a $\mathrm{CH}_{2} \mathrm{Cl}_{2}$ solution of 4 and ca 10 eq of TBACl was dropped onto the collection window of an ATIR spectrometer and the solvent was allowed to evaporate before measurement of the spectrum. 

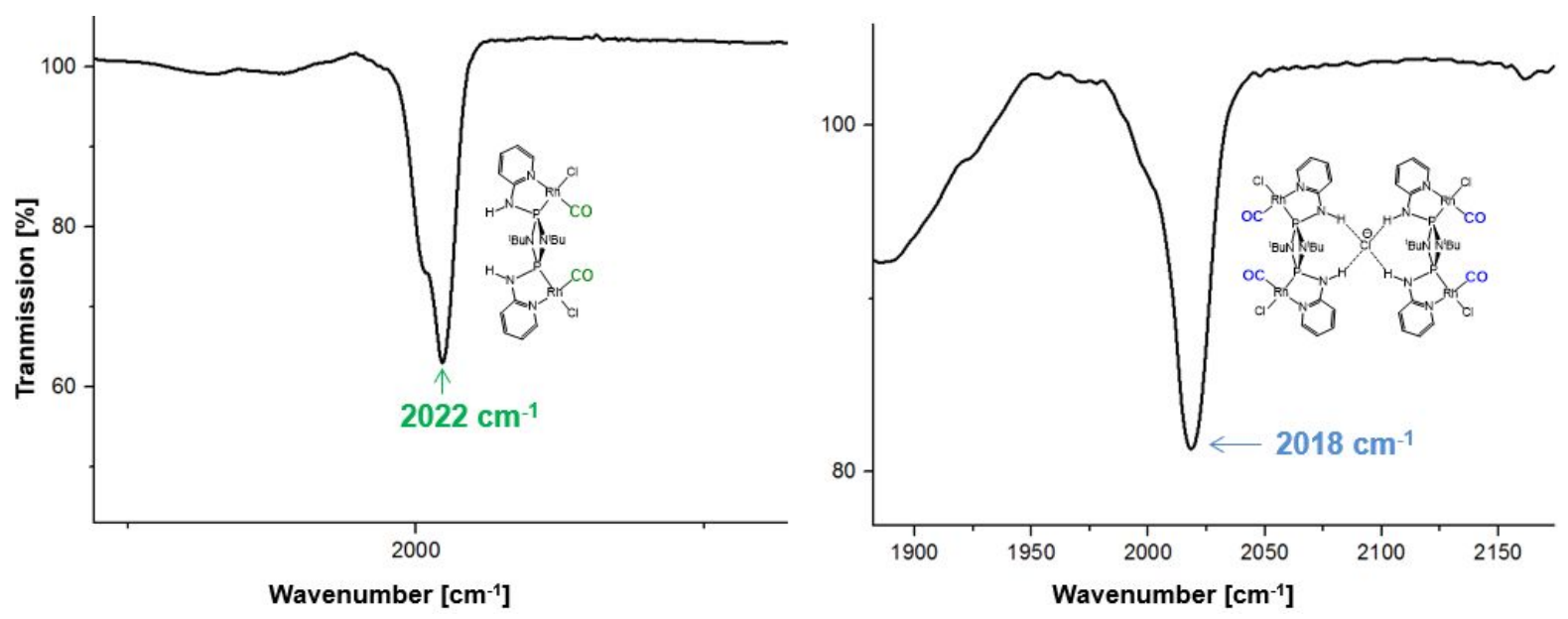

Figure S 43: Solid-state ATIR of 5 before and after addition of TBACl; for collection a $\mathrm{CH}_{2} \mathrm{Cl}_{2}$ solution of $\mathbf{5}$ and ca 10 eq of TBACl was dropped onto the collection window of an ATIR spectrometer and the solvent was allowed to evaporate before measurement of the spectrum.
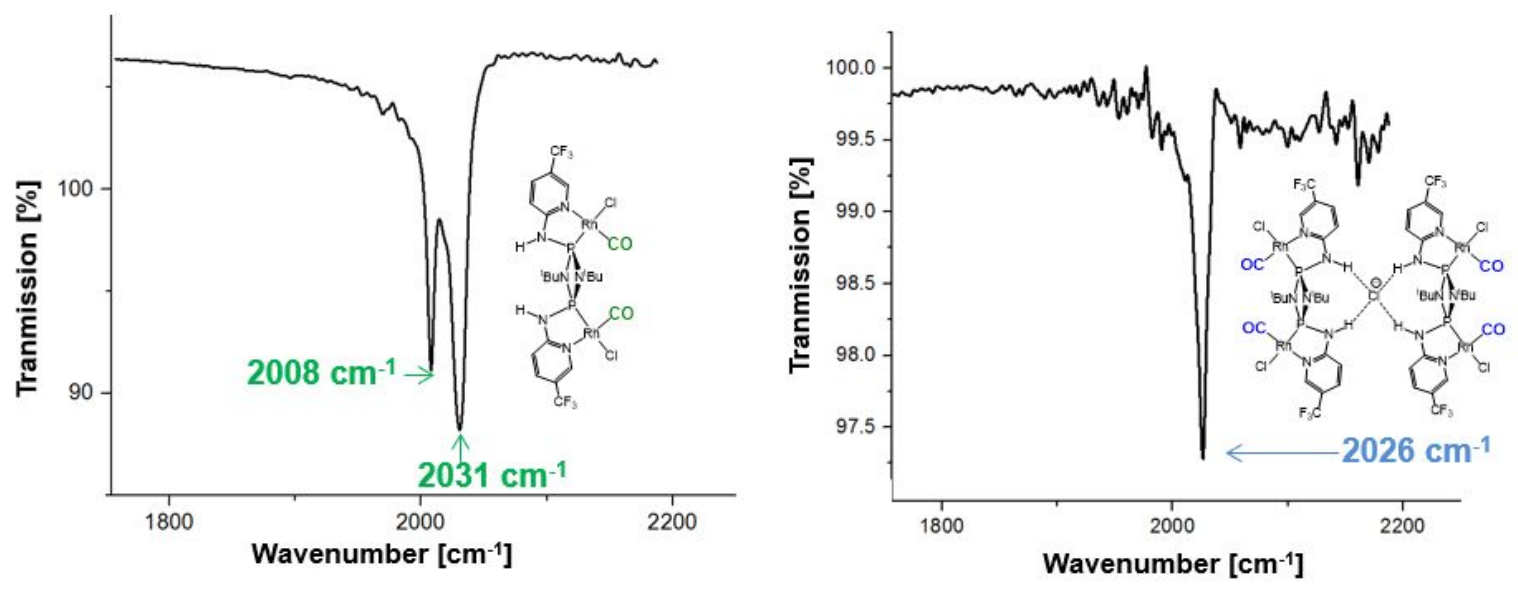

Figure S 44: Solid state ATIR of 7 before and after addition of TBACl; for collection a $\mathrm{CH}_{2} \mathrm{Cl}_{2}$ solution of 7 and ca 10 eq of TBACI was dropped onto the collection window of an ATIR spectrometer and the solvent was allowed to evaporate before measurement of the spectrum.

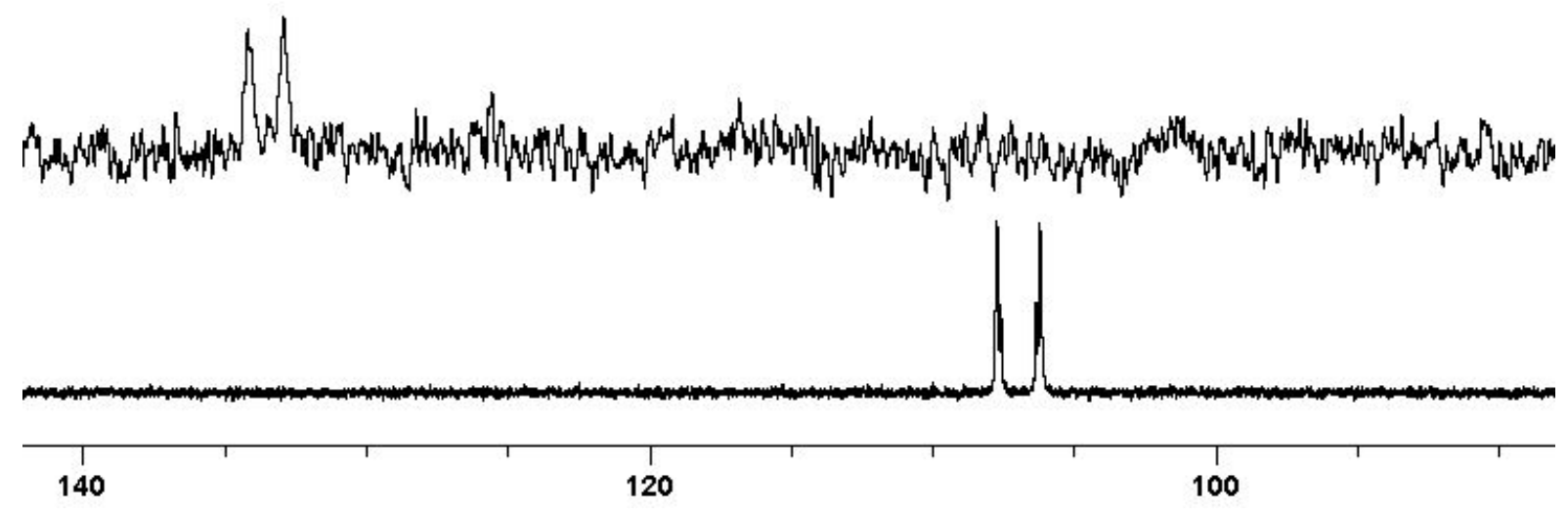

Figure S 45: Overlaid ${ }^{31} \mathrm{P}$ NMR spectra $\left(25^{\circ} \mathrm{C}, \mathrm{d}_{6}-\mathrm{DMSO}, 400 \mathrm{MHz}\right)$ of 7 (bottom) before and (top) after the addition of excess TBAOAc. The behaviour of 5 is analogous. 

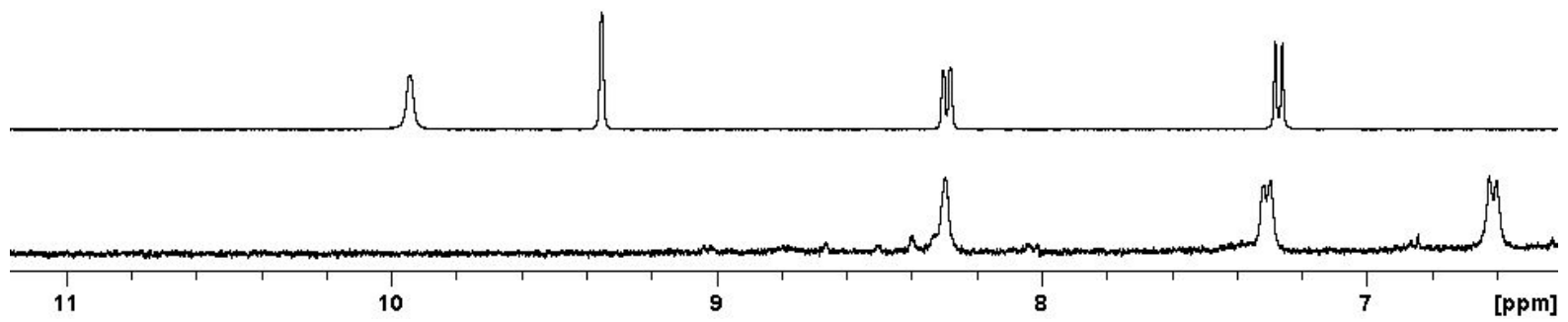

Figure S 46: Overlaid ${ }^{1} \mathrm{H}$ NMR spectra $\left(25^{\circ} \mathrm{C}, \mathrm{d}_{6}\right.$-DMSO, $\left.400 \mathrm{MHz}\right)$ of 7 (bottom) before and (top) after the addition of excess TBAOAc showing loss of the $\mathrm{NH}$ resonance and upfield shifting of the pyridyl resonances in line with deprotonation. The behaviour of $\mathbf{5}$ analogous.

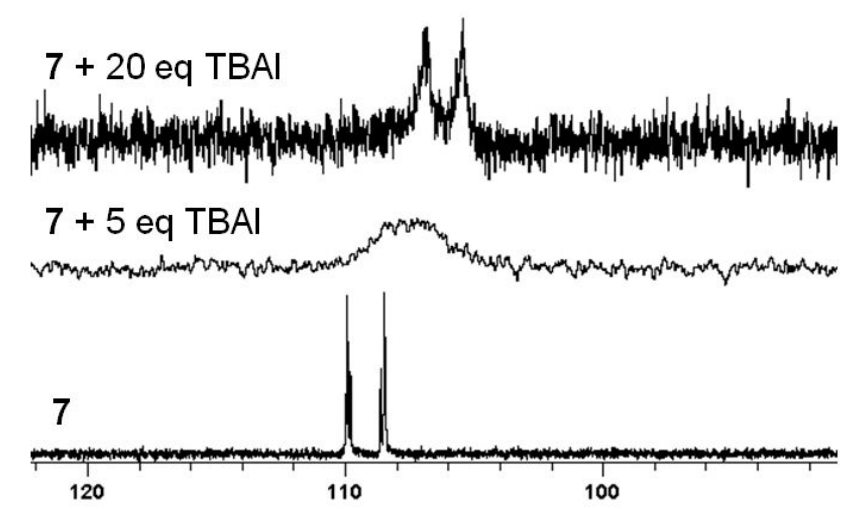

Figure S 47: Overlaid ${ }^{31} \mathrm{P}$ NMR spectra $\left(25^{\circ} \mathrm{C}, \mathrm{CDCl}_{3}, 202 \mathrm{MHz}\right)$ of 7 (bottom) before and after the addition of 5 eq (middle) and 20 eq (top) of TBAl indicating exchange of the chloride ligand on $\mathrm{Rh}(\mathrm{I})$. The behaviour of $\mathbf{5}$ is analogous.

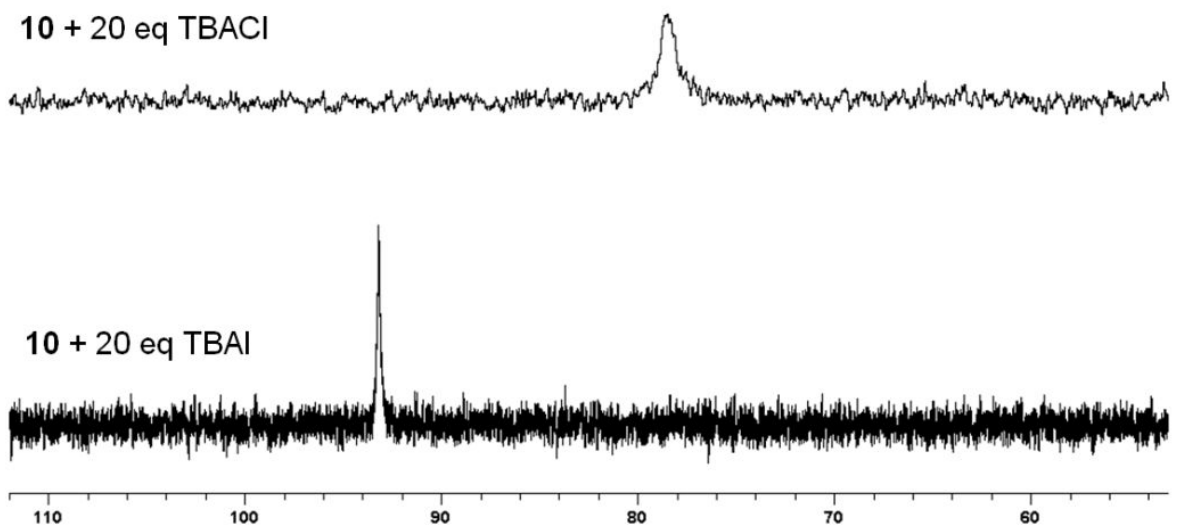

Figure S 48: Overlaid ${ }^{31} \mathrm{P}$ NMR spectra $\left(25^{\circ} \mathrm{C}, \mathrm{CDCl}_{3}, 202 \mathrm{MHz}\right)$ of 10 in presence of $20 \mathrm{eq}$ TBACl (top) and 20 eq TBAI (bottom) indicating exchange of the chloride ligand on $\mathrm{Au}(\mathrm{I})$. The behaviour of 3 is analogous. 


\section{Crystallography}

Table S1 Details of the data collections and refinements of 1, 2, 3, 5

\begin{tabular}{|c|c|c|c|c|}
\hline & 1 & 2 & 3 & 5 \\
\hline CCDC Number & 1948842 & 1948843 & 1948844 & 1948845 \\
\hline Empirical formula & $\mathrm{C}_{18} \mathrm{H}_{28} \mathrm{~N}_{6} \mathrm{P}_{2}$ & $\mathrm{C}_{18} \mathrm{H}_{28} \mathrm{~N}_{6} \mathrm{P}_{2} \mathrm{Se}_{2}$ & $\begin{array}{l}\mathrm{C}_{18.50} \mathrm{H}_{29} \mathrm{Au}_{2} \mathrm{Cl}_{3} \mathrm{~N} \\
{ }_{6} \mathrm{P}_{2}\end{array}$ & $\begin{array}{l}\mathrm{C}_{23} \mathrm{H}_{35.50} \mathrm{Cl}_{2} \mathrm{~N}_{6.50} \\
\mathrm{O}_{3} \mathrm{P}_{2} \mathrm{Rh}_{2} \mathrm{~S}\end{array}$ \\
\hline Formula weight & 390.40 & 548.32 & 897.70 & 821.80 \\
\hline Temperature /K & $180(2)$ & $180(2)$ & $180(2)$ & $180(2)$ \\
\hline Crystal system & Orthorhombic & Triclinic & Monoclinic & Monoclinic \\
\hline Space group & $P_{n a 2}$ & $P 1-$ & $C 2 / c$ & $P 2_{1} / n$ \\
\hline$a / \AA$ & $20.2018(5)$ & $8.7090(3)$ & $10.6147(4)$ & $9.2082(2)$ \\
\hline$\overline{b / \AA}$ & $8.3206(2)$ & $9.1141(3)$ & $15.3663(6)$ & $20.2777(5)$ \\
\hline$\overline{c / \AA}$ & $12.3871(3)$ & $16.3590(6)$ & $34.3889(12)$ & $17.8493(4)$ \\
\hline$\alpha /^{\circ}$ & 90 & $82.152(2)$ & 90 & 90 \\
\hline$\overline{\beta /{ }^{\circ}}$ & 90 & $80.6360(10)$ & $92.3180(10)$ & $104.6660(10)$ \\
\hline $\mathrm{Y} /{ }^{\circ}$ & 90 & $70.7450(10)$ & 90 & 90 \\
\hline$\overline{\text { Volume / } \AA^{3}}$ & $2082.16(9)$ & $1204.72(7)$ & $5604.5(4)$ & $3224.25(13)$ \\
\hline $\bar{Z}$ & 4 & 2 & 8 & 4 \\
\hline$\overline{\rho_{\text {calc }} / \mathrm{g} \mathrm{cm}^{-3}}$ & 1.245 & 1.512 & 2.128 & 1.693 \\
\hline$\mu / \mathrm{mm}^{-1}$ & 2.005 & 5.219 & 23.267 & 11.654 \\
\hline$F(000)$ & 832 & 552 & 3368 & 1652 \\
\hline Crystal size / $\mathrm{mm}^{3}$ & $\begin{array}{l}0.25 \times 0.05 \times \\
0.05\end{array}$ & $\begin{array}{l}0.14 \times 0.11 \times \\
0.05\end{array}$ & $\begin{array}{l}0.20 \times 0.08 \times \\
0.04\end{array}$ & $\begin{array}{l}0.16 \times 0.14 \times \\
0.03\end{array}$ \\
\hline Radiation & $\begin{array}{l}\text { CuKa }(\lambda= \\
1.5418)\end{array}$ & $\begin{array}{l}\text { CuKa }(\lambda= \\
1.5418)\end{array}$ & $\begin{array}{l}\text { CuKa }(\lambda= \\
1.5418)\end{array}$ & $\begin{array}{l}\text { CuKa }(\lambda= \\
1.5418)\end{array}$ \\
\hline$\theta$ range $/{ }^{\circ}$ & 4.38 to 66.76 & 2.748 to 66.663 & 2.572 to 66.666 & 3.362 to 66.682 \\
\hline Reflections collected & 19407 & 12721 & 21130 & 20705 \\
\hline $\begin{array}{l}\text { Independent } \\
\text { reflections }\end{array}$ & 3488 & 4218 & 4939 & 5667 \\
\hline$R_{\text {int }}$ & 0.040 & 0.0307 & 0.0402 & 0.0575 \\
\hline Goodness-of-fit on $F^{2}$ & 1.039 & 1.016 & 1.216 & 1.023 \\
\hline $\begin{array}{l}\text { Data/restraints/param } \\
\text { eters }\end{array}$ & 3488 / 1 / 241 & $4218 / 0 / 259$ & 4939 / 223 / 328 & $5667 / 340 / 377$ \\
\hline$R 1[/>2 \sigma(I)]$ & 0.0265 & 0.0308 & 0.0300 & 0.0390 \\
\hline wR2 [all data] & 0.0633 & 0.0781 & 0.0699 & 0.0959 \\
\hline $\begin{array}{l}\text { Largest diff. peak/hole } \\
\text { / e } \AA^{-3}\end{array}$ & $0.171 /-0.217$ & $0.680 /-0.642$ & $0.908 /-1.435$ & $1.179 /-0.776$ \\
\hline Flack parameter & $0.040(10)$ & N/A & $\mathrm{N} / \mathrm{A}$ & $\mathrm{N} / \mathrm{A}$ \\
\hline
\end{tabular}


Table S2 Details of the data collections and refinements of 4 and 7

\begin{tabular}{|c|c|c|}
\hline & 4 & 7 \\
\hline CCDC Number & 1948846 & 1948847 \\
\hline Empirical formula & $\mathrm{C}_{28} \mathrm{H}_{31} \mathrm{Mo}_{2} \mathrm{~N}_{7} \mathrm{O}_{8} \mathrm{P}_{2}$ & $\mathrm{C}_{22} \mathrm{H}_{26} \mathrm{Cl}_{2} \mathrm{~F}_{6} \mathrm{~N}_{6} \mathrm{O}_{2} \mathrm{P}_{2} \mathrm{Rh}_{2}$ \\
\hline Formula weight & 847.42 & 859.15 \\
\hline Temperature /K & $180(2)$ & $180(2)$ \\
\hline Crystal system & Monoclinic & Monoclinic \\
\hline Space group & $P 2_{1} / n$ & $P 2_{1} / C$ \\
\hline$a / \AA$ & 12.7399(3) & $9.2213(3)$ \\
\hline$\overline{b / \AA}$ & 16.6974(5) & $23.8634(6)$ \\
\hline$c / \AA$ & $17.5104(5)$ & $14.3346(5)$ \\
\hline$\overline{\alpha /{ }^{\circ}}$ & 90 & 90 \\
\hline$\overline{\beta /{ }^{\circ}}$ & $104.029(2)$ & $101.039(2)$ \\
\hline$\overline{\mathrm{Y} /{ }^{\circ}}$ & 90 & 90 \\
\hline Volume / $\AA^{3}$ & $3613.77(17)$ & $3095.99(17)$ \\
\hline $\bar{Z}$ & 4 & 4 \\
\hline$\rho_{\text {calc }} / \mathrm{g} \mathrm{cm}^{-3}$ & 1.558 & 1.843 \\
\hline$\mu / \mathrm{mm}^{-1}$ & 6.989 & 11.818 \\
\hline$\overline{F(000)}$ & 1704 & 1696 \\
\hline Crystal size / mm³ & $0.21 \times 0.10 \times 0.10$ & $0.18 \times 0.03 \times 0.02$ \\
\hline Radiation & CuKa $(\lambda=1.5418)$ & CuKa $(\lambda=1.5418)$ \\
\hline$\theta$ range $/^{\circ}$ & 3.712 to 66.705 & 3.647 to 66.685 \\
\hline Reflections collected & 23661 & 17631 \\
\hline Independent reflections & 6340 & 5421 \\
\hline$R_{\text {int }}$ & 0.0829 & 0.0999 \\
\hline Goodness-of-fit on $F^{2}$ & 1.005 & 1.054 \\
\hline Data/restraints/parameters & $6340 / 246 / 431$ & $5421 / 433 / 395$ \\
\hline$R 1[/>2 \sigma(I)]$ & 0.0434 & 0.0498 \\
\hline wR2 [all data] & 0.0805 & 0.0980 \\
\hline \multicolumn{2}{|c|}{ Largest diff. peak/hole /e $\AA^{-3}$ 0.458/-0.553 } & $0.847 /-0.886$ \\
\hline Flack parameter & $\mathrm{N} / \mathrm{A}$ & $\mathrm{N} / \mathrm{A}$ \\
\hline
\end{tabular}




\section{Refinement special details}

All data sets were collected using a Bruker D8 VENTURE diffractometer equipped with high-brilliance I $\mu \mathrm{S}$ Cu-Ka radiation $(1.54178 \AA$ ), with $\omega$ and $\psi$ scans at $180(2) \mathrm{K}$. Data integration and reduction were undertaken with SAINT ${ }^{[3]}$ in the APEX3 software suite, and multi-scan empirical absorption corrections were applied to the data using SADABS. ${ }^{4]}$ Subsequent computations were carried out using the WinGX-32 ${ }^{[5]}$ graphical user interface. Structures were solved by direct methods using SHELXT-2013 ${ }^{[6]}$ then refined and extended with SHELXL-2013. ${ }^{[6]}$ In all cases, nitrogen-bound hydrogens were identified in the electron density map and their thermal parameters were allowed to ride on the attached nitrogen atom. Crystallographic data along with specific details pertaining to the refinements follow. Crystallographic data have been deposited with the CCDC (CCDC 1948842-1948847).

1. No special refinement details.

Table S3.Hydrogen bonds for $1\left[\AA\right.$ and $\left.{ }^{\circ}\right]$.

$\overline{D-H} \ldots A \quad d(D-H) \quad d(H \ldots A) \quad d(D \ldots A) \quad<(D H A)$

$\begin{array}{lllll}\overline{\mathrm{N}(3)}-\mathrm{H}(1 \mathrm{~N} 3) \ldots \mathrm{N}(6) & 0.71(3) & 2.19(3) & 2.872(3) & 161(4) \\ \mathrm{N}(5)-\mathrm{H}(1 \mathrm{~N} 5) \ldots \mathrm{N}(4) \# 1 & 0.86(3) & 2.41(3) & 3.244(3) & 164(3)\end{array}$

Symmetry transformations used to generate equivalent atoms:

$\# 1-x+1,-y+1, z+1 / 2$

2. No special refinement details.

Table S4. Hydrogen bonds for $2\left[\AA\right.$ and $\left.{ }^{\circ}\right]$.

\begin{tabular}{lllll}
$\overline{\mathrm{D}-\mathrm{H}} \ldots \mathrm{A}$ & $\mathrm{d}(\mathrm{D}-\mathrm{H})$ & $\mathrm{d}(\mathrm{H} \ldots \mathrm{A})$ & $\mathrm{d}(\mathrm{D} \ldots \mathrm{A})$ & $<(\mathrm{DHA})$ \\
\hline$\overline{\mathrm{N}(3)-\mathrm{H}(1 \mathrm{~N} 3) \ldots \mathrm{N}(6)}$ & & & & \\
$\mathrm{N}(5)-\mathrm{H}(1 \mathrm{~N} 5) \ldots \mathrm{Se}(2) \# 1$ & $0.75(4)$ & $2.16(4)$ & $2.927(3)$ & $163(4)$ \\
& & $2.85(4)$ & $3.558(2)$ & $158(3)$ \\
\hline
\end{tabular}

Symmetry transformations used to generate equivalent atoms:

$\# 1-x+1,-y+1,-z+2$ 
3. One molecule of DCM was modelled as disordered over two parts, and sits on a symmetry position. Distance (DFIX) and bond angle (DANG) restraints were applied to the disordered parts of the DCM molecule to facilitate anisotropic refinement. Nitrogen-bound hydrogens were restrained to have similar bond lengths (SADI). $\mathrm{H}$-bonds between molecules of $\mathbf{3}$ are listed below.

Table S5. Hydrogen bonds for $3\left[\AA\right.$ and $\left.{ }^{\circ}\right]$.

\begin{tabular}{lllll}
\hline $\mathrm{D}-\mathrm{H} \ldots \mathrm{A}$ & $\mathrm{d}(\mathrm{D}-\mathrm{H})$ & $\mathrm{d}(\mathrm{H} \ldots \mathrm{A})$ & $\mathrm{d}(\mathrm{D} \ldots \mathrm{A})$ & $<(\mathrm{DHA})$ \\
\hline $\mathrm{N}(3)-\mathrm{H}(1 \mathrm{~N} 3) \ldots \mathrm{Cl}(1) \# 1$ & $0.73(5)$ & $2.49(5)$ & $3.220(5)$ & $175(7)$ \\
$\mathrm{N}(5)-\mathrm{H}(1 \mathrm{~N} 5) \ldots \mathrm{N}(4)$ & $0.73(5)$ & $2.23(6)$ & $2.933(7)$ & $162(8)$ \\
\hline
\end{tabular}

Symmetry transformations used to generate equivalent atoms:

$\# 1-x+1, y,-z+1 / 2$

5. One molecule of MeCN sits on a symmetry position and its disordered part is thus symmetry generated; this molecule was placed in PART -1. Distance (DFIX), bond angle (DANG) and thermal parameter (SIMU, DELU) restraints were applied to the MeCN molecule to facilitate anisotropic refinement. $\mathrm{H}$-bonds between $\mathbf{5}$ and DMSO are listed below.

Table S6. Hydrogen bonds for $5\left[\AA\right.$ and $\left.{ }^{\circ}\right]$.

\begin{tabular}{lcccc}
$\overline{\mathrm{D}-\mathrm{H}} \ldots \mathrm{A}$ & $\mathrm{d}(\mathrm{D}-\mathrm{H})$ & $\mathrm{d}(\mathrm{H} \ldots \mathrm{A})$ & $\mathrm{d}(\mathrm{D} \ldots \mathrm{A})$ & $<(\mathrm{DHA})$ \\
\hline$\overline{\mathrm{N}(3)-\mathrm{H}(1 \mathrm{~N} 3) \ldots \mathrm{O}(3)}$ & & & & \\
$\mathrm{N}(5)-\mathrm{H}(1 \mathrm{~N} 5) \ldots \mathrm{O}(3)$ & $0.84(5)$ & $2.05(5)$ & $2.869(5)$ & $167(5)$ \\
& & $1.92(5)$ & $2.842(5)$ & $167(5)$ \\
\hline
\end{tabular}

4. No special refinement details. $\mathrm{H}$-bonds between $\mathbf{4}$ and $\mathrm{MeCN}$ are listed below.

Table S7. Hydrogen bonds for $4\left[\AA\right.$ and $\left.{ }^{\circ}\right]$.

$\overline{D-H} \ldots A \quad d(D-H) \quad d(H \ldots A) \quad d(D \ldots A) \quad<(D H A)$

\begin{tabular}{lllll}
\hline $\mathrm{N}(3)-\mathrm{H}(1 \mathrm{~N} 3) \ldots \mathrm{N}(30)$ & $0.75(8)$ & $2.48(8)$ & $3.170(7)$ & $154(9)$ \\
$\mathrm{N}(5)-\mathrm{H}(1 \mathrm{~N} 5) \ldots \mathrm{N}(30)$ & $0.78(8)$ & $2.41(8)$ & $3.163(6)$ & $162(9)$
\end{tabular}


7. One $\mathrm{CF}_{3}$ group was modelled as disordered over two positions and the thermal parameter of disordered $F$ atoms were constrained to be identical (EADP). 


\section{Computational Details}

Structure optimisations were performed using the Turbomole V7.3 program package ${ }^{[7]}$ at DFT level with the B3LYP hybrid functional[8,9], the triple- $\zeta$ basis set def2-TZVPP ${ }^{[10,11]}$ and ECPs def2-ecp for Mo, Rh and $\mathrm{Au}^{[12]}$ on an $\mathrm{m} 5$ grid. Dispersion correction by Grimme (D3) ${ }^{[13]}$ and Becke-Johnson damping (BJ) ${ }^{[14]}$ was employed for the calculations as implemented. Minimum structures were confirmed by frequency analysis within the harmonic approximation as implemented in the Turbomole code. QTAIM analysis was performed as implemented. ${ }^{[15]}$ NBO analysis was carried out using the NBO7.0 program ${ }^{[16]}$ in the Gaussian $16^{[17]}$ interface. For visualization the program VMD V1.9.3 was used. ${ }^{[18]}$

\section{Results:}

We have analysed the most favourable conformation of ligand 1 and the selenium oxidised ligand 2. As anticipated, we found that the endo-exo conformer is the most stable in both cases due to the intramolecular hydrogen bond, also observed in the solid state. The Plll case the exo-exo conformer is $26.88 \mathrm{~kJ} / \mathrm{mol}$ less stable and the endo-endo conformer $43.73 \mathrm{~kJ} / \mathrm{mol}$. In the $\mathrm{P}^{\vee}$ case the exo-exo conformer is $72.37 \mathrm{~kJ} / \mathrm{mol}$ less stable, the endo-endo conformer 35.08 $\mathrm{kJ} / \mathrm{mol}$. The results are summarised in Table S8.

Table S8. Thermochemistry of ligand conformers of $\mathbf{1}$ and 2. Energy in $\mathrm{kJ} / \mathrm{mol}$.

\begin{tabular}{lll}
\hline & $\mathbf{1}$ & $\mathbf{2}$ \\
\hline Endo-exo & 0 & 0 \\
\hline Endo-endo & 43.73 & 35.08 \\
\hline Exo-exo & 26.88 & 72.37 \\
\hline
\end{tabular}

Additionally, we have analysed the metal complexes 3, 4 and 5 with an NBO analysis as well as QTAIM. Figure S49-S52 show the NPA of $\mathbf{4}$ and $\mathbf{5}$ in comparison with the free ligand $\mathbf{1}$ (exo-exo conformer). The population of the phosphorus changes significantly from 1.32 in the free ligand to 1.64 in the molybdenum complex 4 and 1.65 in the Rh complex 5. Interestingly, the population of all nitrogen atoms hardly changes, including the pyridyl nitrogen which coordinates the metal centre. 


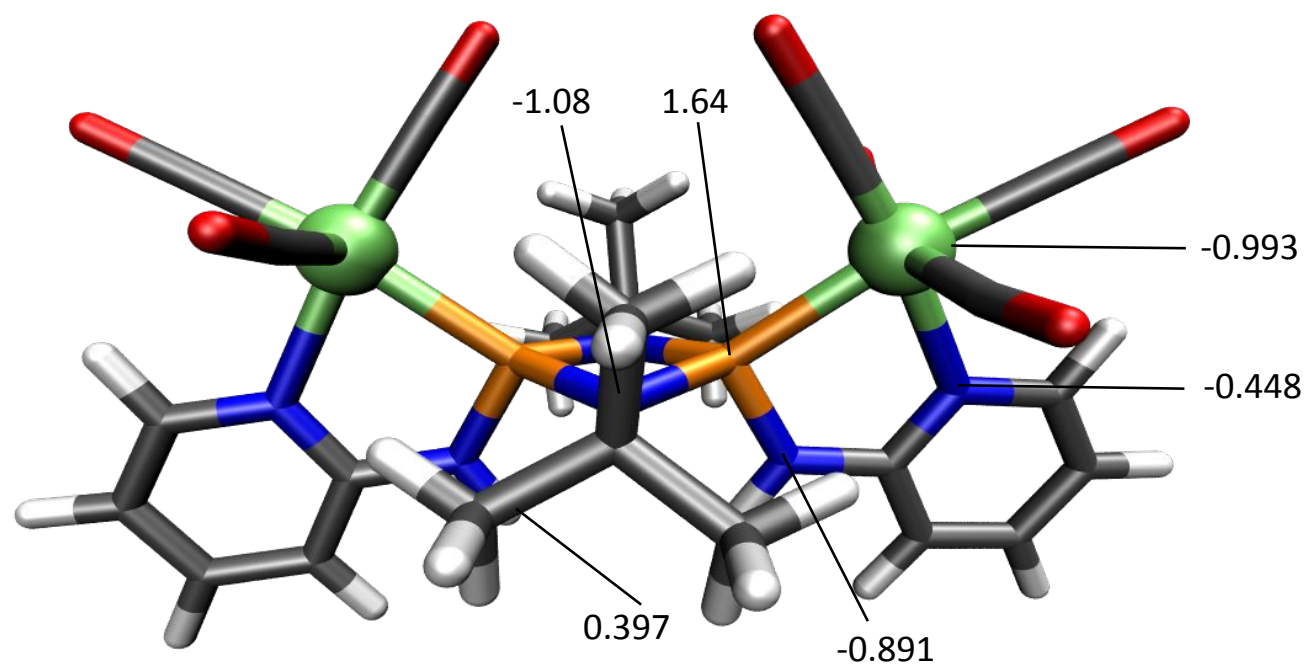

Figure S 49: Selected NPA charges of 4.

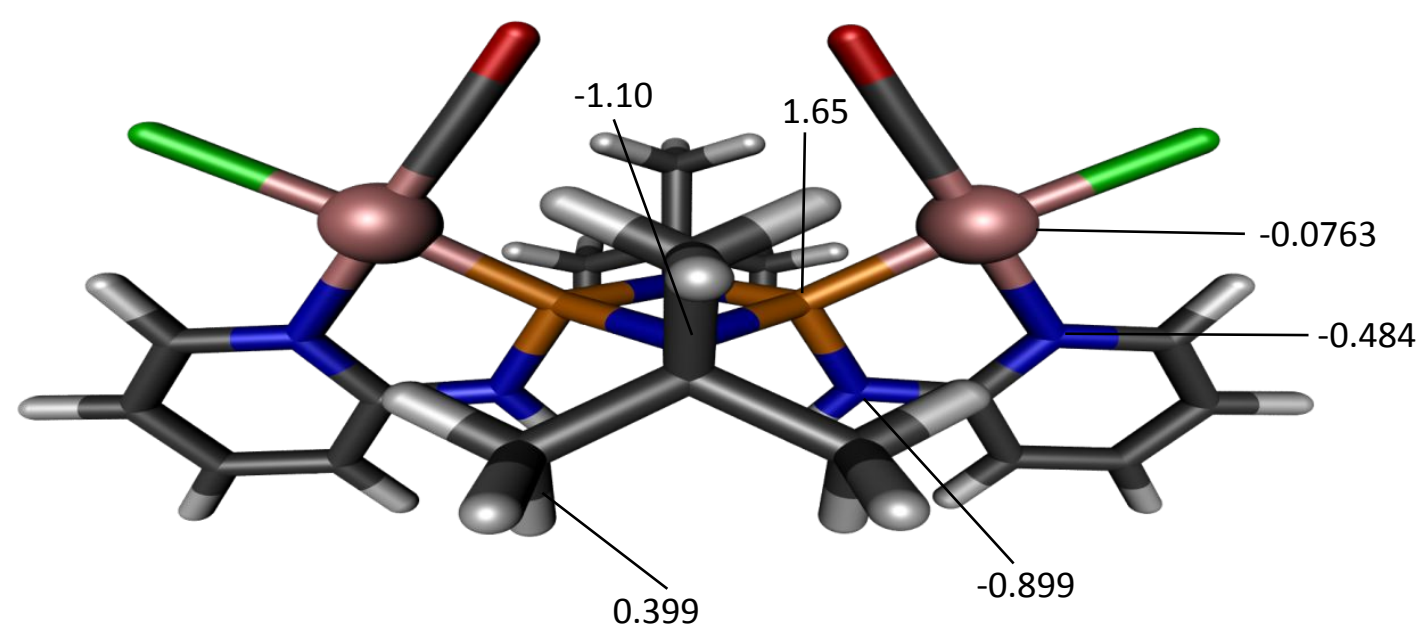

Figure S 50: Selected NPA charges of 5.

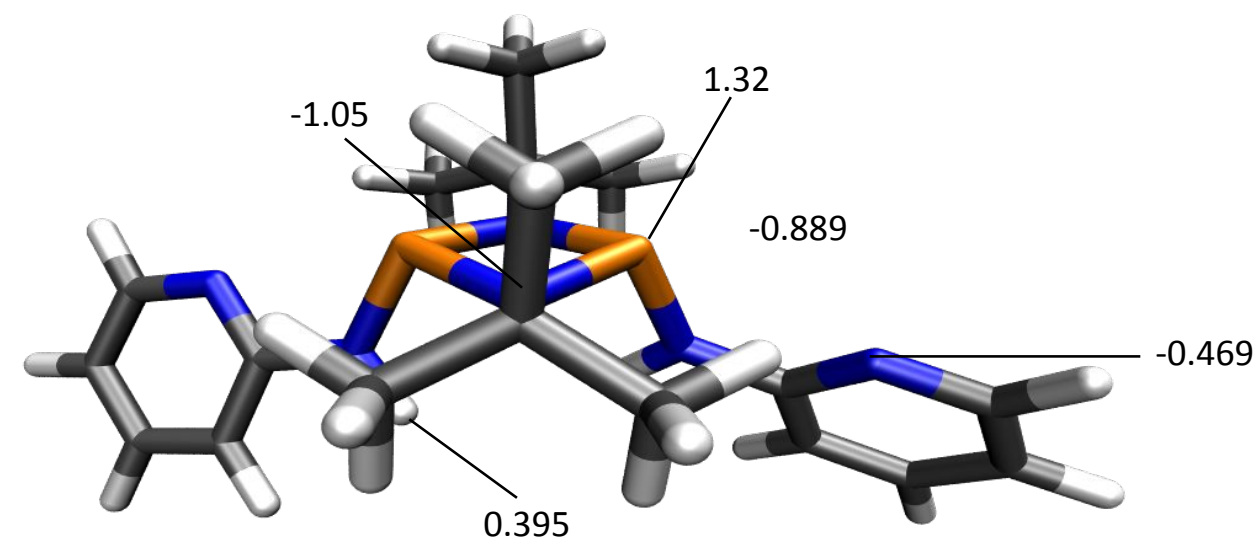

Figure S 51: Selected NPA charges of 1. 
In the NBO analysis we focused on the delocalisation of the exocyclic nitrogen lone pairs in the $\mathrm{P}_{2} \mathrm{~N}_{2}$ ring, i.e. the $\sigma^{*}\left(\mathrm{P}-\mathrm{N}_{\text {endo }}\right)$ orbital, the delocalisation of the endocyclic nitrogen lone pairs in the $\sigma^{*}\left(P-N_{\text {exo }}\right)$ orbital as well as delocalisation in metal based orbitals. For calculations with the free ligand we have chosen the exo-exo conformer since its geometry is best comparable to the ligand geometry in the metal complexes. In the free ligand, the interaction between the exocyclic nitrogen lone pair with the $\sigma^{*}\left(\mathrm{P}-\mathrm{N}_{\text {endo }}\right)$ orbital (Figure $\mathrm{S} 52$ ) is computed to 42.47 $\mathrm{kJ} / \mathrm{mol}$. This interaction explains the tilting of the $\mathrm{NH}$-pyridyl moieties to allow for better orbital overlap. The interaction energy between the $N_{\text {exo }}$ lone pair with the other $\sigma^{*}\left(P-N_{\text {endo }}\right)$ (not shown in Figure $S 52)$ is less significant $(6.90 \mathrm{~kJ} / \mathrm{mol})$ due to a smaller orbital overlap. In case of the metal complexes 4 and 5 this interaction is weaker (Mo: $31.09 \mathrm{~kJ} / \mathrm{mol}$, Rh: $27.32 \mathrm{~kJ} / \mathrm{mol}$ ). This trend can be explained with the increasing planarisation of the $\mathrm{NH}$-pyridyl moieties which is dictated by the coordination environment of the metal but is no longer ideal for this orbital overlap (Figure S 53, Figure S 54). However, the increased overlap with the other $\sigma^{\star}\left(\mathrm{P}-\mathrm{N}_{\text {endo }}\right)$ orbitals overcompensates the loss delocalisation energy and leads to an overall increase when summing up the interaction energies: $1: 49.37 \mathrm{~kJ} / \mathrm{mol}, 4: 54.43 \mathrm{~kJ} / \mathrm{mol}, 5: 54.31 \mathrm{~kJ} / \mathrm{mol}$.

For 3 the interaction of the exocyclic nitrogen lone pair with the $\sigma^{*}\left(P-N_{\text {endo }}\right)$ orbital (Figure $S$ 58) is calculated to $46.11 \mathrm{~kJ} / \mathrm{mol}$ for the stronger interaction and $28.08 \mathrm{~kJ} / \mathrm{mol}$ for the interaction with the other $\mathrm{P}_{2} \mathrm{~N}_{2}$ orbital. Note that the conformation of the pyridyl arms is exoendo to enable the formation of a $\mathrm{H}$-bond (red dashed line in Figure $\mathrm{S} 58$ ) whereas in complexes 4 and $\mathbf{5}$ the pyridyl arms have an exo-exo conformation. Therefore, for better comparison we have discussed the exo arm of 3.

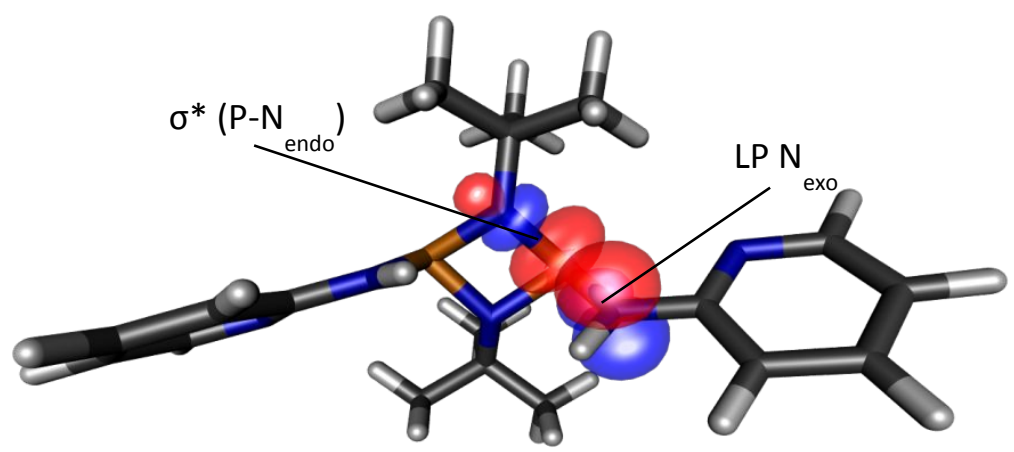

Figure S 52: Selected NBOs ( $\sigma^{*}\left(P-N_{\text {endo }}\right)$ and $\left.L P N_{\text {exo }}\right)$ of free ligand 1.

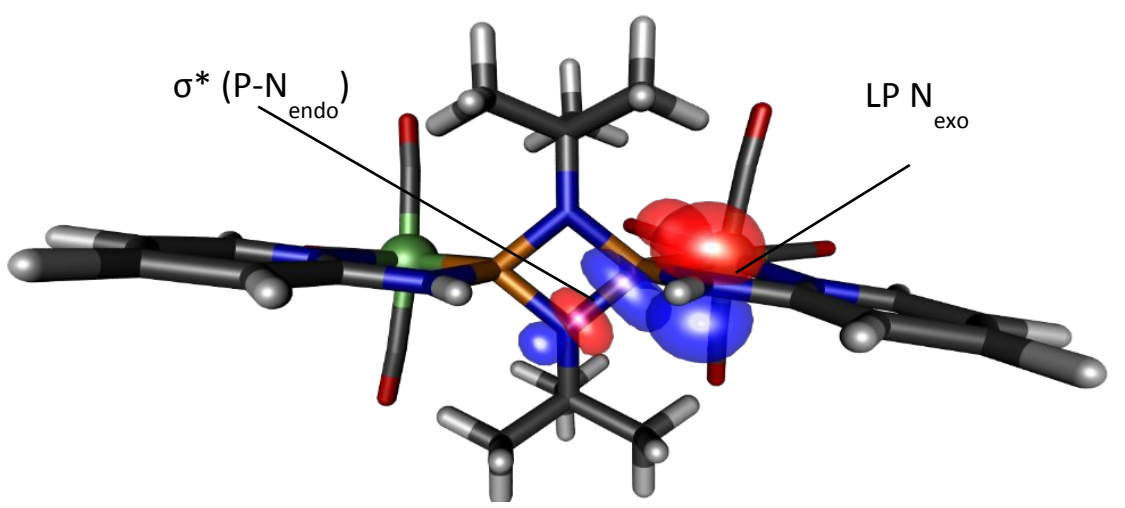

Figure S 53: Selected NBOs ( $\sigma^{*}\left(P-N_{\text {endo }}\right)$ and $\left.L P N_{\text {exo }}\right)$ of complex 4. 


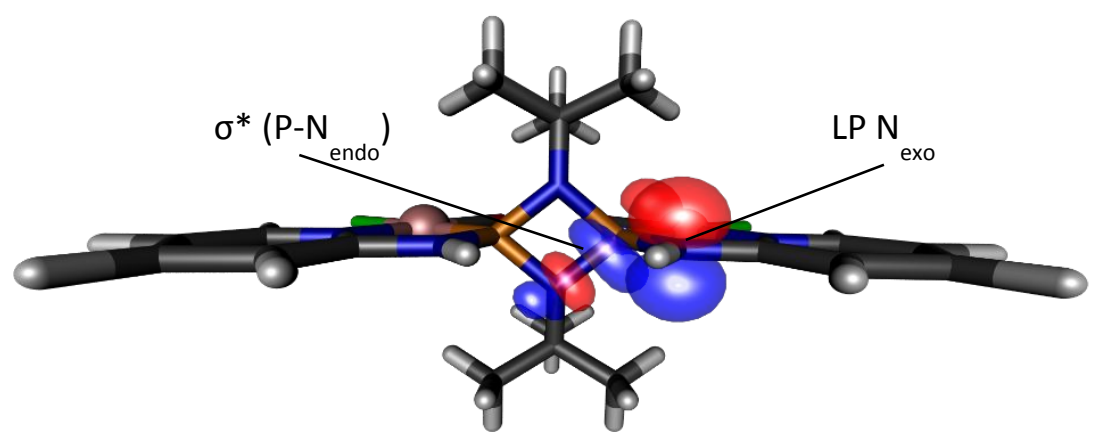

Figure S 54: Selected NBOs $\left(\sigma^{*}\left(P-N_{\text {endo }}\right)\right.$ and LP $\left.N_{\text {exo }}\right)$ of complex 5.

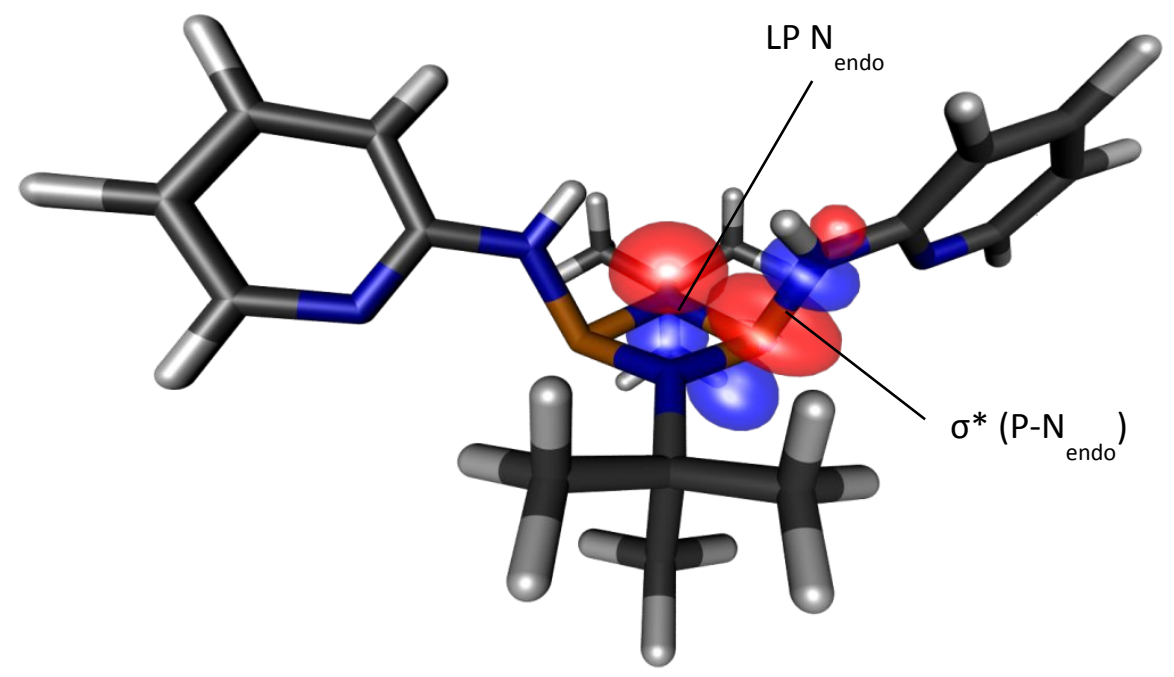

Figure S 55: Selected NBOs $\left(\sigma^{*}\left(P-N_{\text {exo }}\right)\right.$ and LP $\left.N_{\text {endo }}\right)$ of free ligand 1.

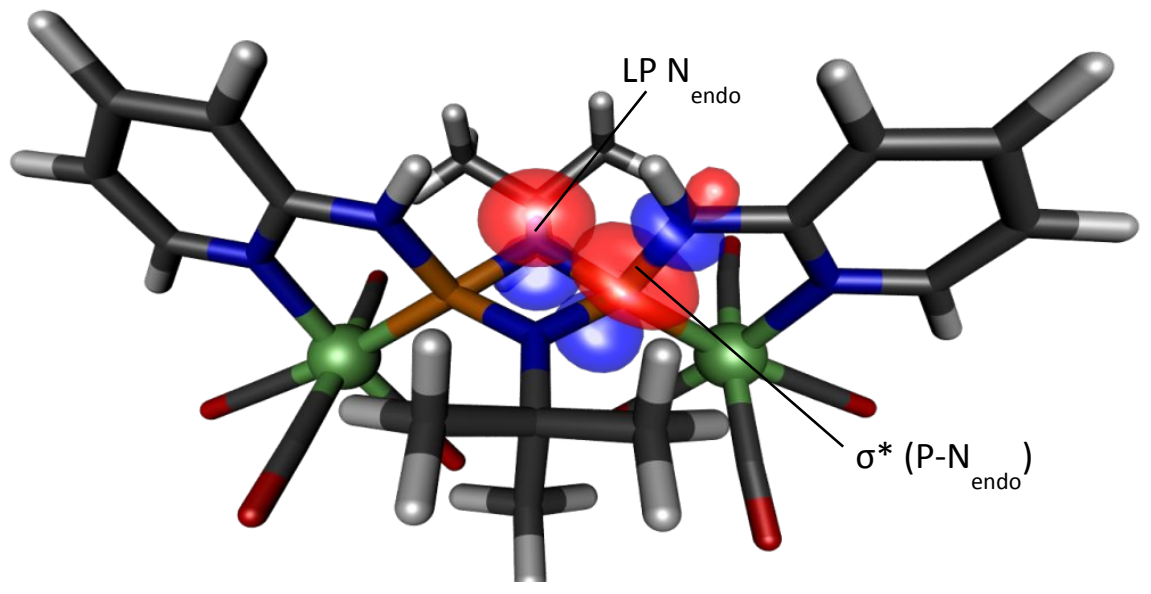

Figure S 56: Selected NBOs $\left(\sigma^{*}\left(P-N_{\text {exo }}\right)\right.$ and LP $\left.N_{\text {endo }}\right)$ of complex 4.

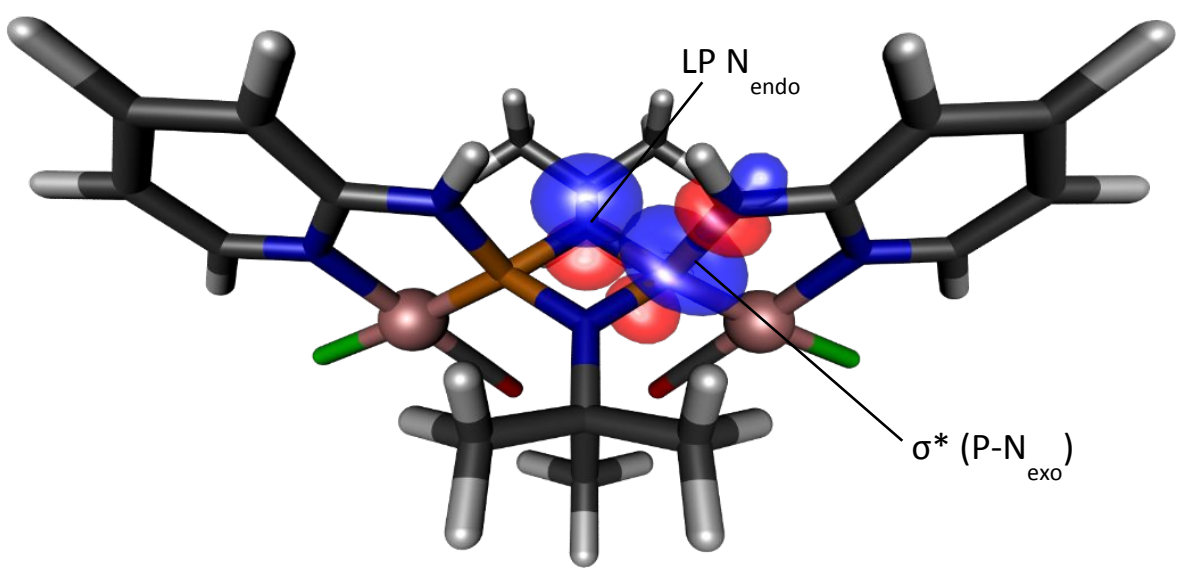


Figure S 57: Selected NBOs $\left(\sigma^{*}\left(P-N_{e x o}\right)\right.$ and LP $\left.N_{\text {endo }}\right)$ of complex 5.

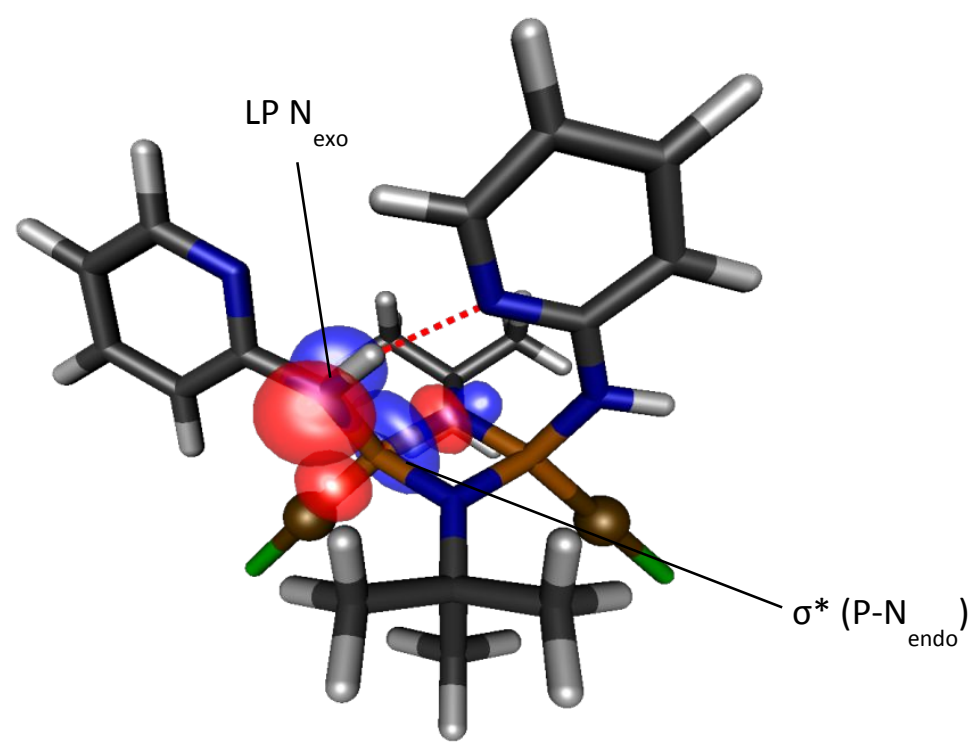

Figure S 58: Selected NBOs NBOs $\left(\sigma^{*}\left(P-N_{\text {endo }}\right)\right.$ and LP $\left.N_{\text {exo }}\right)$ of complex 3.

The Interaction between the $\mathrm{N}_{\text {endo }}$ lone pair with the $\sigma^{*}\left(\mathrm{P}-\mathrm{N}_{\text {exo }}\right)$ orbital (Figure 7-9) weaker in the free ligand $(36.23 \mathrm{~kJ} / \mathrm{mol}$ ) than in the metal complexes (Mo: $49.16 \mathrm{~kJ} / \mathrm{mol}$, Rh: 46.78 $\mathrm{kJ} / \mathrm{mol})$.

The free ligand 1 as well as the complexes 4 and $\mathbf{5}$ bind chloride via hydrogen bonding. Therefore, we have studied the corresponding chloride complexes. We calculated the relative chloride ion affinity which is lowest for the free ligand (anchor point, $0 \mathrm{~kJ} / \mathrm{mol}$ ), followed by the Mo complex $(5.42 \mathrm{~kJ} / \mathrm{mol})$ while the Rh complex has the highest affinity towards chloride $(102.05 \mathrm{~kJ} / \mathrm{mol})$. A possible explanation for this is the increase in polarisation of the $\mathrm{N}-\mathrm{H}$ bond upon metal coordination indicated by the natural charges $(\triangle \mathrm{NPA}(\mathrm{N}-\mathrm{H}) \mathbf{1}=1.284, \mathbf{4}=1.288, \mathbf{5}$ $=1.298$, Figure S49-S52). Additionally, in the optimised structures of the chloride complexes $1 \cdot \mathrm{Cl}^{-}, 4 \cdot \mathrm{Cl}^{-}$and $5 \cdot \mathrm{Cl}^{-}$(Figure $\mathrm{S}$ 62-64) the $\mathrm{NH}$-pyridyl moieties point in the same direction to achieve a chelating binding pocket for the chloride anion. The $\mathrm{NH}$-pyridyl moieties in the minimum structure of the free ligand 1 have a tilted arrangement, whereas the metal complexes $\mathbf{4}$ and $\mathbf{5}$ already show this planar structure, meaning the metal coordination preorientates the binding pocket and therefore enhances the binding strength. 
In case of ligand chloride complex $1 \cdot \mathrm{Cl}^{-}$, the interaction energy between the lone pair of the exocyclic nitrogen atom and the $\sigma^{*}\left(\mathrm{P}-\mathrm{N}_{\text {endo }}\right)$ orbital as well as the interaction energy between the lone pair of the endocyclic nitrogen atom and the $\sigma^{*}\left(\mathrm{P}-\mathrm{N}_{\mathrm{exo}}\right)$ orbital increases slightly in comparison to ligand 1 . In case of the molybdenum chloride complex $4 \cdot \mathrm{Cl}^{-} \mathrm{N}_{\text {exo }} \rightarrow \sigma^{*}(\mathrm{P}-$ $\left.N_{\text {endo }}\right)$ interaction energy drops, whereas the $N_{\text {endo }} \rightarrow \sigma^{*}\left(P-N_{\text {exo }}\right)$ interaction energy rises in comparison to $\mathbf{5}$. In the rhodium complex the interaction energies are largely unaffected. The results are summarised in Tables S9 and S10.

Table S9. Interaction energies of $\mathrm{N}_{\text {exo }} \rightarrow$ $\sigma^{*}\left(\mathrm{P}-\mathrm{N}_{\text {endo }}\right)$ orbital of the host and the chloride complex. Energy values in $\mathrm{kJ} / \mathrm{mol}$.

\begin{tabular}{lll}
\hline & $\begin{array}{l}\text { neutral } \\
\text { host }\end{array}$ & $\begin{array}{l}\text { chloride } \\
\text { complex }\end{array}$ \\
\hline $\mathbf{1}$ & 36.23 & 41.88 \\
\hline $\mathbf{4}$ & 49.16 & 39.46 \\
\hline $\mathbf{5}$ & 49.78 & 49.86
\end{tabular}

Table S10. Interaction energies of $\mathrm{N}_{\text {endo }}$ $\rightarrow \sigma^{*}\left(P-N_{\text {exo }}\right)$ orbital of the host and the chloride complex. Energy values in $\mathrm{kJ} / \mathrm{mol}$.

Binding of a chloride ion leads to weaker $\pi$ acceptor capabilities of the phosphorus centre in the ligand. This is concluded the backbonding, i.e. the delocalisation energy of a molybdenum based lone pair into a phosphorus-based Rydberg orbital (Figure S 59-61). In case of 4 this energy is calculated to $22.22 \mathrm{~kJ} / \mathrm{mol}$. For $\mathbf{4} \cdot \mathbf{C l}^{-}$this interaction is only $11.84 \mathrm{~kJ} / \mathrm{mol}$. Donation of the Mo lone pair in the $\sigma^{*}\left(P-N_{\text {endo }}\right)$ orbitals is weaker $(8.33 \mathrm{~kJ} / \mathrm{mol}$ and $0.67 \mathrm{~kJ} / \mathrm{mol})$ for 4 and weaker for $4 \cdot \mathrm{Cl}^{-}(1.13 \mathrm{~kJ} / \mathrm{mol}$ and $<0.21 \mathrm{~kJ} / \mathrm{mol})$. In addition to this the $\sigma$ donor capability follows an opposite trend. The delocalisation energy of the phosphorus based lone pair in the opposite $\sigma^{*}(\mathrm{Mo}-\mathrm{C})$ orbital for 4 is $625.30 \mathrm{~kJ} / \mathrm{mol}$ and for $761.95 \mathrm{~kJ} / \mathrm{mol} \mathbf{4} \cdot \mathbf{C l}^{-}$.

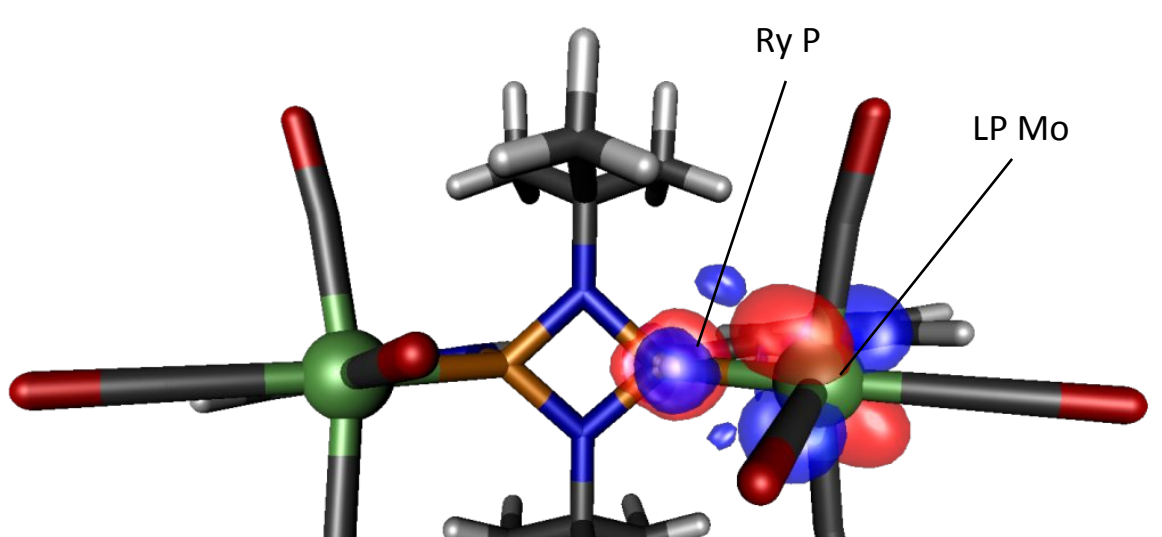


Figure S 59:. Selected NBOs (LP Mo and Ry P) of complex 4

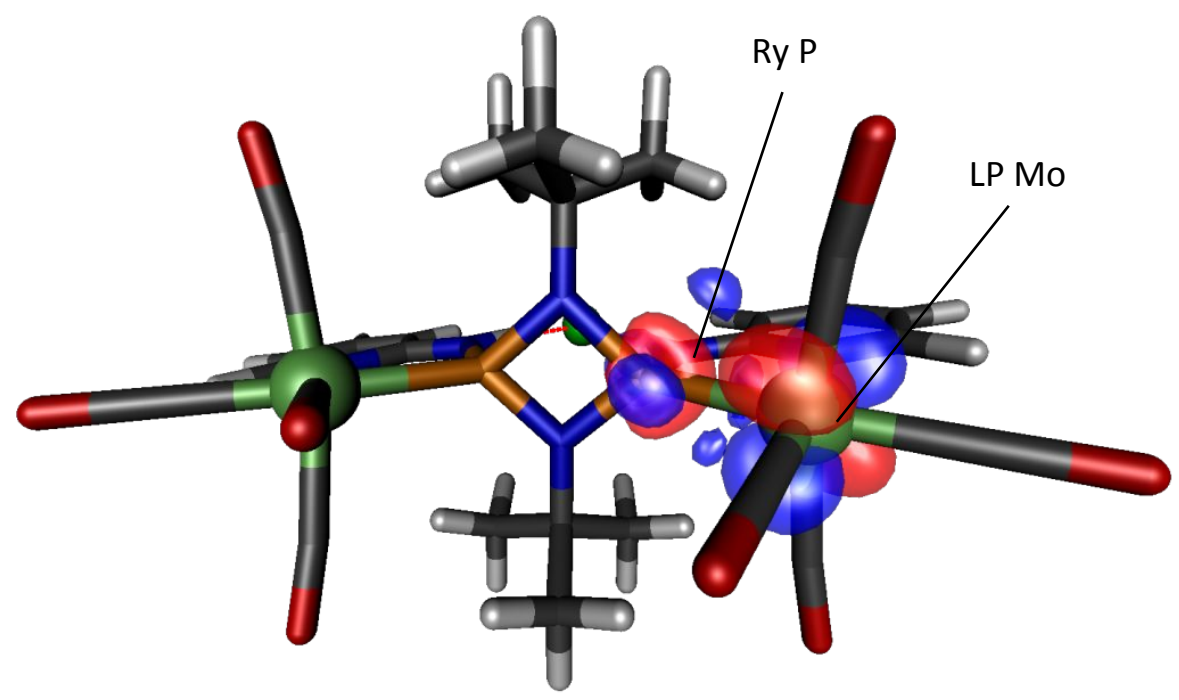

Figure S 60: Selected NBOs (LP Mo and Ry P) of complex $4 \cdot \mathrm{Cl}^{-}$

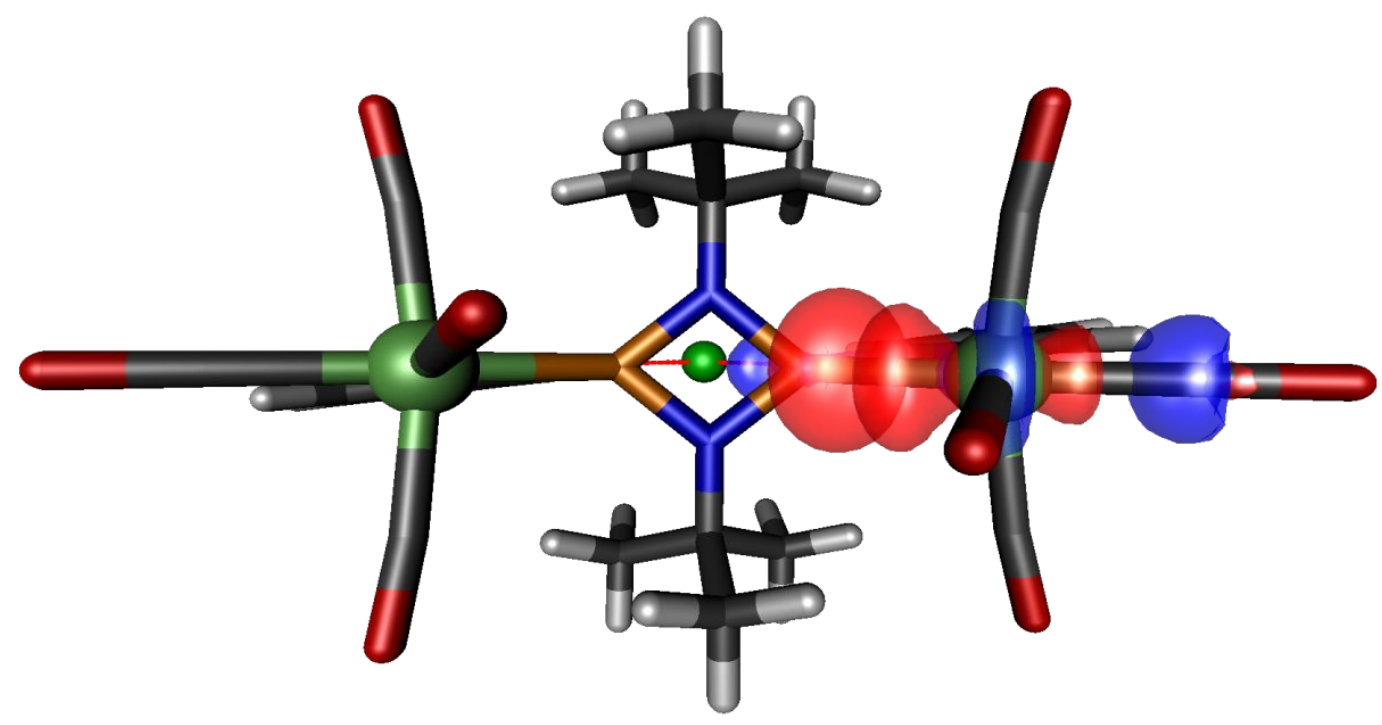

Figure S 61: Selected NBOs (LP P and $\sigma{ }^{*}(\mathrm{Mo}-\mathrm{C})$ ) of complex $4 \cdot \mathrm{Cl}^{-}$. 
Furthermore, we performed a QTAIM analysis. The electron density at the bond critical points (BCPs) in the ligand backbone was analysed for the free ligand 1, complex $\mathbf{4}$ and $\mathbf{5}$ as well as their chloride complexes $1 \cdot \mathrm{Cl}^{-}, 4 \cdot \mathrm{Cl}^{-}, \mathbf{5} \cdot \mathrm{Cl}^{-}$. The results are summarised in Table S11. Upon coordination of the metal fragments, the electron density at the BCPs in the ligand backbone increases. This effect is more pronounced for Rh than for Mo. The Laplacian $\nabla^{2} \rho$ in the ligand backbone also increases upon coordination of the metal fragment indicating that the interaction has more closed shell nature, i.e. ionic character. This is validated by the NPA (Figure S49-S52) showing higher natural charges at the phosphorus in the metal complexes 4 and 5 in comparison to the free ligand 1 (1: 1.32, 4: 1.64, 5: 1.65). The nitrogen atoms show a similar but less pronounced trend.

Table S11. QTAIM results: electron density and Laplacian at selected BCPs of 1, 4, 5 and the chloride complexes $1 \cdot \mathrm{Cl}^{-}, 4 \cdot \mathrm{Cl}^{-}, 5 \cdot \mathrm{Cl}^{-}$.

\begin{tabular}{|c|c|c|c|c|c|c|}
\hline \multirow[t]{2}{*}{ BCP } & \multicolumn{6}{|c|}{$\begin{array}{l}\text { Electron density } \rho \\
\left(\text { Laplacian } \nabla^{2} \rho\right)\end{array}$} \\
\hline & $\mathbf{X}$ & A & B & $\mathrm{X} \cdot \mathrm{Cl}^{-}$ & $\mathrm{A} \cdot \mathrm{Cl}^{-}$ & $\mathrm{B} \cdot \mathrm{Cl}^{-}$ \\
\hline $\mathrm{N}-\mathrm{H}$ & $\begin{array}{c}0.3493 \\
(-1.892)\end{array}$ & $\begin{array}{c}0.3499 \\
(-1.899)\end{array}$ & $\begin{array}{c}0.3506 \\
(-1.916)\end{array}$ & $\begin{array}{c}0.3275 \\
(-1.897)\end{array}$ & $\begin{array}{c}0.3191 \\
(-1.869)\end{array}$ & $\begin{array}{c}0.3172 \\
(-1.871)\end{array}$ \\
\hline $\mathrm{P}-\mathrm{N}(\mathrm{exo})$ & $\begin{array}{l}0.1592 \\
(1.190)\end{array}$ & $\begin{array}{c}0.1621 \\
(0.2815)\end{array}$ & $\begin{array}{c}0.1633 \\
(0.2771)\end{array}$ & $\begin{array}{c}0.1633 \\
(0.2596)\end{array}$ & $\begin{array}{c}0.1711 \\
(0.3235)\end{array}$ & $\begin{array}{c}0.1733 \\
(0.3180)\end{array}$ \\
\hline P-N(endo) & $\begin{array}{c}0.1616 / \\
0.1651 \\
(0.1660 / \\
0.2029)\end{array}$ & $\begin{array}{c}0.1685 / \\
0.1708 \\
(0.2232 / \\
0.2389)\end{array}$ & $\begin{array}{c}0.1728 / \\
0.1728 \\
(0.2519 / \\
0.2520)\end{array}$ & $\begin{array}{c}0.1628 / \\
0.1642 \\
(0.2085 / \\
0.2090)\end{array}$ & $\begin{array}{c}0.1723 / \\
0.1700 \\
(0.2621 / \\
0.2495)\end{array}$ & $\begin{array}{c}0.1737 / \\
0.1735 \\
(0.2719 / \\
0.2705)\end{array}$ \\
\hline N-M & - & $\begin{array}{c}0.0595 \\
(0.2460)\end{array}$ & $\begin{array}{c}0.0844 \\
(0.3414)\end{array}$ & - & $\begin{array}{c}0.0595 \\
(0.2375)\end{array}$ & $\begin{array}{c}0.0844 \\
(0.3361)\end{array}$ \\
\hline P-M & - & $\begin{array}{c}0.0729 \\
(0.1661)\end{array}$ & $\begin{array}{c}0.1298 \\
(0.1504)\end{array}$ & - & $\begin{array}{c}0.0721 \\
(0.1523)\end{array}$ & $\begin{array}{r}0.1299 \\
(0.1302)\end{array}$ \\
\hline
\end{tabular}

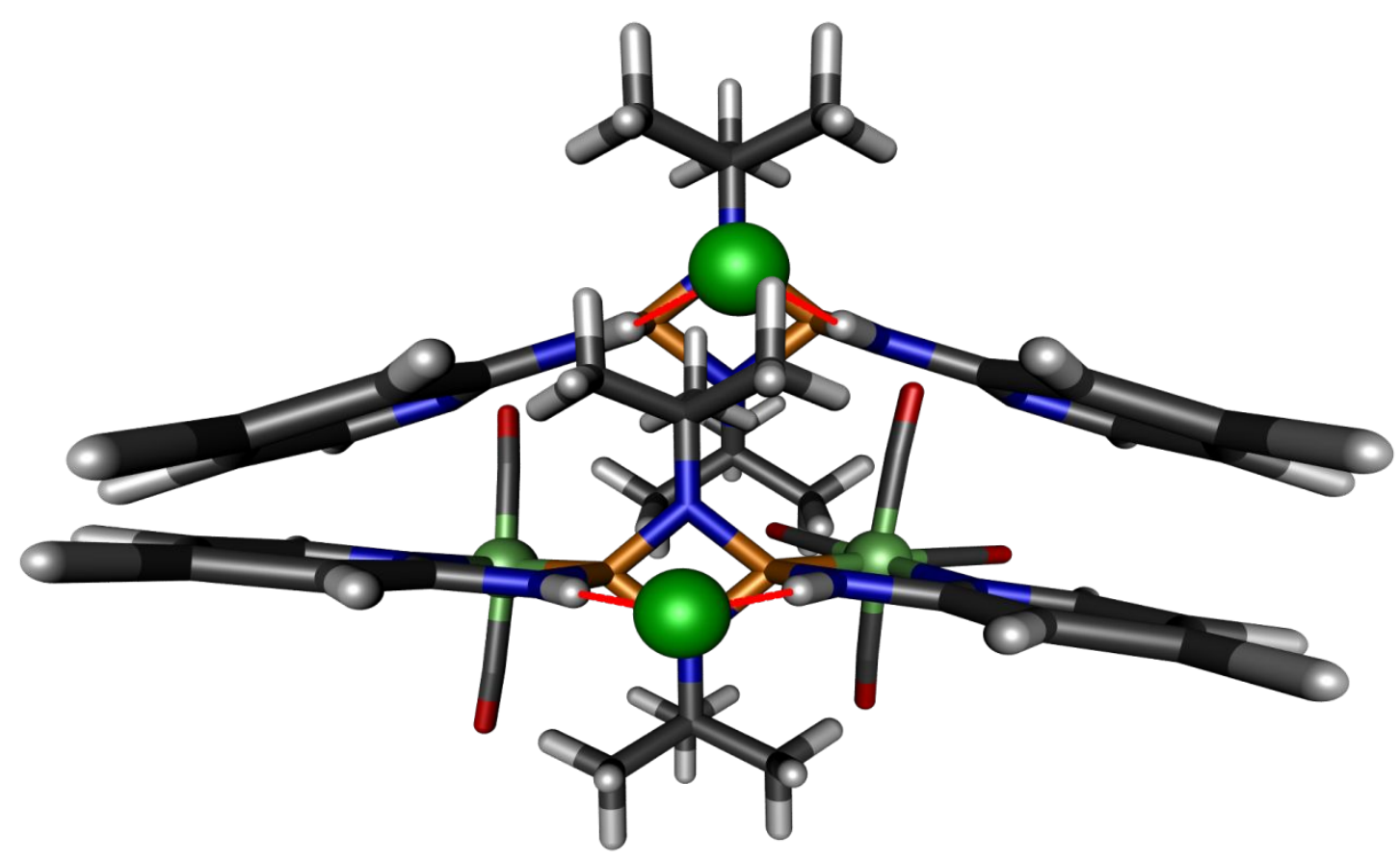


Figure S 62: Optimised structure of $1 \cdot \mathrm{Cl}^{-}$. Hydrogen bonds displayed in red.

Figure S 63: Optimised structure of $4 \cdot \mathrm{Cl}^{-}$. Hydrogen bonds displayed in red.

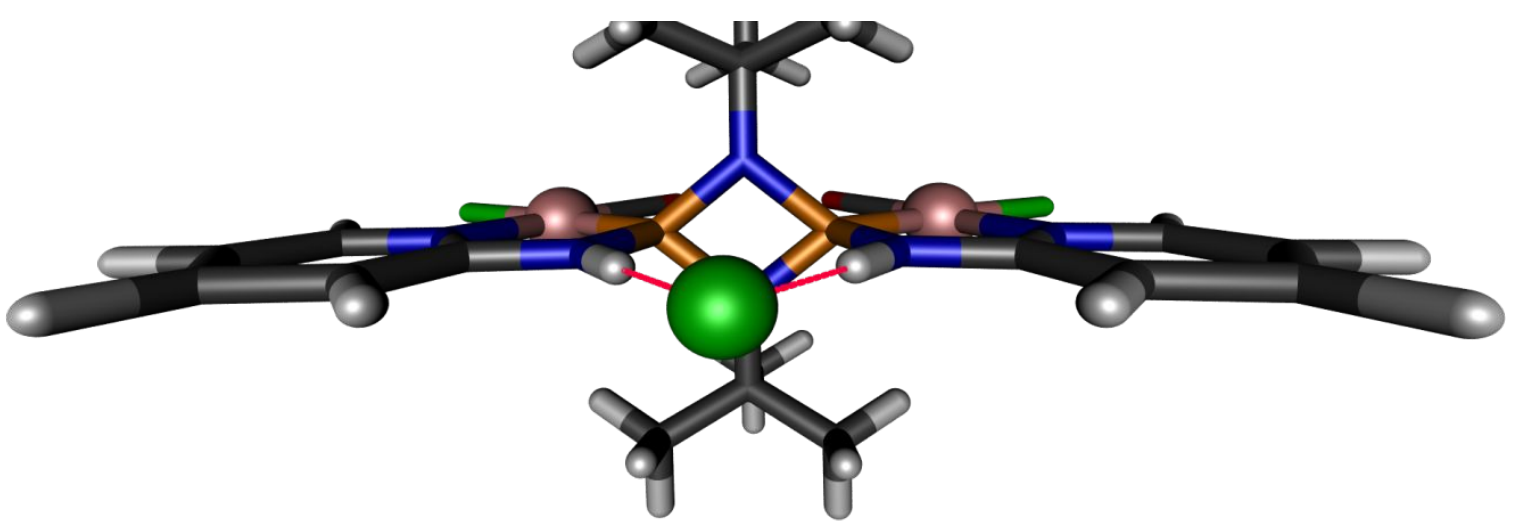

Figure S 64: Optimised structure of $5 \cdot \mathrm{Cl}^{-}$. Hydrogen bonds displayed in red.

\section{Ion transport study}

\section{Abbreviations}

POPC: 2-oleoyl-1-palmitoyl-sn-glycero-3-phosphocholine;

HPTS: 8-hydroxypyrene-1,3,6-trisulfonic acid;

PB: phosphate buffer;

HEPES: N-(2-Hydroxyethyl)piperazine-N'-(2-ethanesulfonic acid);

LUVs: large unilamellar vesicles;

Fl: fluorescence intensity. 


\section{Experiment details}

\section{Materials}

POPC, HPTS, lucigenin and Sephadex G-50 were purchased from Sigma. Fluorescence measurements were performed on a Cary Eclipse Fluorescence Spectrophotometer (Agilent Technologies, U.S.A.).

\section{2. $\mathrm{Cl}^{-}$transport activity studied by lucigenin assay}

\subsection{Preparation of POPC-LUVs Jlucigenin and anion carrier contained LUVs}

To prepare the POPC-LUVs evaporating $0.4 \mathrm{~mL}$ of POPC (20 mg/mL in chloroform) under reduced pressure on a rotary evaporator at $45^{\circ} \mathrm{C}$ and then in high vacuum under room temperature for $1 \mathrm{~h} .0 .4 \mathrm{~mL}$ of $\mathrm{PB}$ (phosphate buffer) solution with lucigenin ( $1 \mathrm{mM}$ lucigenin, $5 \mathrm{mM}$ sodium phosphate, $225 \mathrm{mM}$ $\mathrm{NaNO}_{3}, \mathrm{pH} 7.5$ ) was added to rehydrate the lipid film. The resulting suspension was subjected to 5 freeze/thaw cycles and extruded through a polycarbonate membrane (pore size $200 \mathrm{~nm}$ ) for 29 times. Unencapsulated lucigenin was removed by a self-made Sephadex (G-50) column, and finally about $0.9 \mathrm{~mL}$ of POPC-LUVs Jlucigenin solution ( $11.6 \mathrm{mM}$ POPC; solution inside the vesicle: $1 \mathrm{mM}$ lucigenin, $5 \mathrm{mM}$ sodium phosphate, $225 \mathrm{mM} \mathrm{NaNO}_{3}, \mathrm{pH}=$ 7.5; solution outside the vesicle: $5 \mathrm{mM}$ sodium phosphate, $225 \mathrm{mM} \mathrm{NaNO}, \mathrm{pH}=7.5$ ) was gained. To study the anion exchange as shown in Figure $8 \mathrm{~b}, \mathrm{NaCl}$ contained PB solution (1 $\mathrm{mM}$ lucigenin, $5 \mathrm{mM}$ sodium phosphate, $100 \mathrm{mM} \mathrm{NaCl}, \mathrm{pH}=7.5$ ) was used to prepare the POPC-LUVsJlucigenin.

To prepare the anion carrier contained POPC-LUVs chloroform) was premixed with POPC (20 mg/mL in chloroform), then the $0.4 \mathrm{~mL}$ mixture was dried in the same way to obtain the thin lipid film (premixing method). The following procedure was the same with the above operation, and a final volume of around $0.9 \mathrm{~mL}$ of POPC-anion carrier-LUVs Jlucigenin solution ( $11.6 \mathrm{mM}$ POPC; solution inside the vesicles: $1 \mathrm{mM}$ lucigenin, $5 \mathrm{mM}$ sodium phosphate, $225 \mathrm{mM} \mathrm{NaNO}_{3}, \mathrm{pH}=7.5$; solution outside the vesicles: $5 \mathrm{mM}$ sodium phosphate, $225 \mathrm{mM} \mathrm{NaNO} 3, \mathrm{pH}=7.5$ ) was gained.

\section{2 $\mathrm{Cl}$ transport across POPC-LUVs}

The schematic diagram of lucigenin assay is given in Figure 8. As the assay shown in Figure $8 \mathrm{a}$ and Figure 9, $20 \mu \mathrm{L}$ of vesicle solution was diluted with $980 \mu \mathrm{L}$ of PB (5 mM sodium phosphate, $\mathrm{pH}=7.5,225 \mathrm{mM} \mathrm{NaNO}_{3}$ ) in a dry cuvette. $5 \mu \mathrm{L}$ of $4 \mathrm{M} \mathrm{NaCl}$ was added to the extravesicular buffer to induce a $20 \mathrm{mM}$ chloride gradient across the lipid membrane at $t=0.5$ min after the start of the recording, and $10 \mu \mathrm{L}$ anion carrier molecule in acetonitrile was added at $t=1.5 \mathrm{~min}$ to initiate the transport (the addition of anion carrier at $1.5 \mathrm{~min}$ is not needed for premixing method, Figure 10). $20 \mu \mathrm{L}$ of $10 \mathrm{wt} \%$ Triton $\mathrm{X}-100$ was added to lyse the vesicles for calibration at $t=6 \mathrm{~min}$. The change of fluorescence intensity of the lucigenin with time was recorded at $505 \mathrm{~nm}$ with the excitation wavelength of $455 \mathrm{~nm}$. Fluorescence time courses of lucigenin were also normalized to fractional emission intensity $I_{\mathrm{t}}$ according to equation [E1]:

$$
I_{\mathrm{t}}=\left(F_{\mathrm{t}}-F_{\infty}\right) /\left(F_{0}-F_{\infty}\right)
$$


where $F_{\mathrm{t}}$ is fluorescence intensity at time $\mathrm{t}, F_{0}=F_{\mathrm{t}}$ before addition of $\mathrm{NaCl}$ and $F_{\infty}=F_{\mathrm{t}}$ after complete leakage with Triton X-100.

For the assay shown in Figure $8 \mathrm{~b}$ and Figure 11, $20 \mu \mathrm{L}$ of $\mathrm{NaCl}$ contained POPCLUVs $\mathrm{pH}=7.5,100 \mathrm{mM} \mathrm{NaX}, \mathrm{X}=\mathrm{NO}_{3}, \mathrm{HCO}_{3}, \mathrm{SO}_{4}$ ) in a dry cuvette. $10 \mu \mathrm{L}$ of $10 \mu \mathrm{M} 7$ was added at $0.5 \mathrm{~min}$ to induce the ion exchange across the membrane.

\section{Ion transport activity studied by HPTS assay}

\subsection{Preparation of POPC-LUVs دHPTS}

A thin lipid film was gained by evaporating $0.4 \mathrm{~mL}$ of POPC (20 mg/mL in chloroform) under reduced pressure on a rotary evaporator at $45^{\circ} \mathrm{C}$ and then in high vacuum under room temperature for $1 \mathrm{~h}$. After that the lipid film was rehydrated with $0.4 \mathrm{~mL}$ HEPES buffer containing HPTS (1 mM HPTS, 10 mM HEPES, $100 \mathrm{mM} \mathrm{NaCl}, \mathrm{pH} 6.7$ ) by vortexing and then sonicated for $15 \mathrm{~min}$. NaX-HPTS buffer containing HPTS (1 mM HPTS, $10 \mathrm{mM}$ HEPES, , pH $6.7,100 \mathrm{mM} \mathrm{NaX}, \mathrm{X}=\mathrm{NO}_{3}$ or $\mathrm{SO}_{4}$ ) was used to rehydrate the lipid for anion selectivity study. Subsequently, the resulting suspension was subjected to 5 freeze/thaw cycles and extruded through a polycarbonate membrane (pore size $200 \mathrm{~nm}$ ) for 29 times. Finally, the unencapsulated HPTS was removed by a Sephadex (G-50) column and a final volume of around $0.9 \mathrm{~mL}$ of POPC-LUVs $\supset$ HPTS solution ( 11.6 mM POPC; solution inside the vesicles: $1 \mathrm{mM}$ HPTS, $10 \mathrm{mM}$ HEPES, $100 \mathrm{mM} \mathrm{NaCl}, \mathrm{pH}=6.7$; solution outside the vesicles: $10 \mathrm{mM}$ HEPES, $100 \mathrm{mM} \mathrm{NaCl}, \mathrm{pH}=6.7$ ) was obtained.

\subsection{Ion transport activity studied across POPC-LUVsدHPTS}

The schematic diagram of HPTS assay is given in Figure $S$ 65. To obtain the $E C_{50}$ data of different anion carriers as shown in Figure S 66 and Table S12, $10 \mu \mathrm{L}$ of POPC-LUVs $\supset$ HPTS solution prepared as described above and $990 \mu \mathrm{L}$ of HEPES buffer (10 mM HEPES, $100 \mathrm{mM}$ $\mathrm{NaCl}, \mathrm{pH}$ 6.7) were mixed in a dry cuvette. $6.3 \mu \mathrm{L}$ of $0.5 \mathrm{M} \mathrm{NaOH}$ was added into the extravesicular buffer to induce a $\mathrm{pH}$ gradient $(\Delta \mathrm{pH}=0.8)$ across the lipid membrane at $t=0.5$ min after the start of the recording, anion carrier molecule $(10 \mu \mathrm{L}$ in acetonitrile at varied concentration) was added to initiate the ion transport at $t=1.5 \mathrm{~min}$, and $20 \mu \mathrm{L}$ of $10 \mathrm{wt} \%$ Triton $\mathrm{X}-100$ was added to lyse the vesicles for calibration at $t=6 \mathrm{~min}$. The change of fluorescence intensity of the HPTS with time was recorded at $510 \mathrm{~nm}$ with the excitation wavelength of 450 $\mathrm{nm}$. Fluorescence time courses were normalized to fractional emission intensity $l_{\mathrm{t}}$, according to equation [E2].

$$
I_{\mathrm{t}}^{\prime}=\left(F_{\mathrm{t}}-F_{0}\right) /\left(F_{\infty}-F_{0}\right) \quad[\mathrm{E} 2],
$$

where $F_{\mathrm{t}}$ is fluorescence intensity at time $\mathrm{t}, F_{0}=F_{\mathrm{t}}$ before the addition of carrier molecule and $F_{\infty}=F_{\mathrm{t}}$ at saturation after complete leakage achieved with the $10 \mathrm{wt} \%$ Triton $\mathrm{X}-100$. Fractional emission intensity $I_{\mathrm{t}}$ at $6 \mathrm{~min}$ (the time point before the addition of Trition X-100) were plotted as a function of carrier molecule concentration and fitted to the Hill equation [E3] to give the effective concentration $E C_{50}$ (the concentration of carrier molecule showing half activity respect to the maximum) and the Hill coefficient $n$.

$$
I=I_{\infty}+\left(I_{0}-I_{\infty}\right) /\left[1+\left(c / E C_{50}\right)^{n}\right]
$$


Where $c$ is the concentration of carrier molecule, $I_{0}$ is fractional emission intensity without carrier molecule, and $I_{\infty}$ is fractional emission intensity with excess of carrier molecule.

As shown in Figure S 65, we changed the buffer solution inside or outside of the vesicles to study the transport mechanism and test its selectivity for different cations (Figure S 67) and anions (Figure S 68).

\section{Figures and tables}

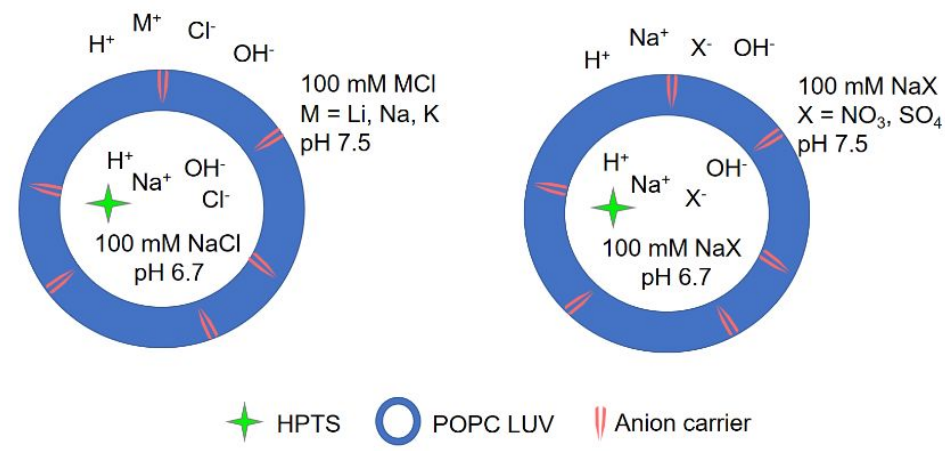

Figure S 65: Schematic diagram of the HPTS assay used to test the selectivity of carrier molecule for transport of cations (left) and anions (right) across the membrane.

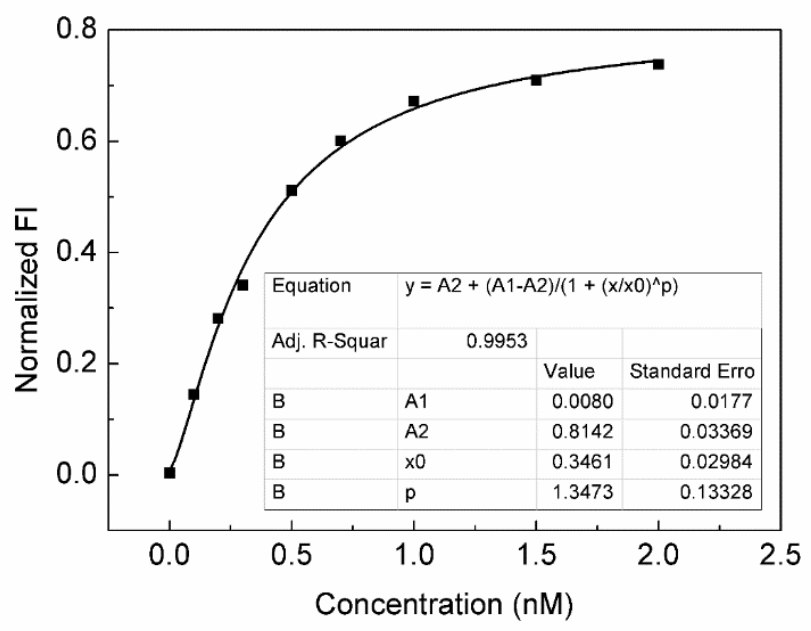


Figure S 66: Change of the normalized fluorescence intensity of HPTS from 1.5 min to 6 min as a function of 7 concentrations across POPC-LUVsDHPTS. EC $C_{50}$ value for 7 gained from the Hill plot was given in the inset table $(x 0)$.

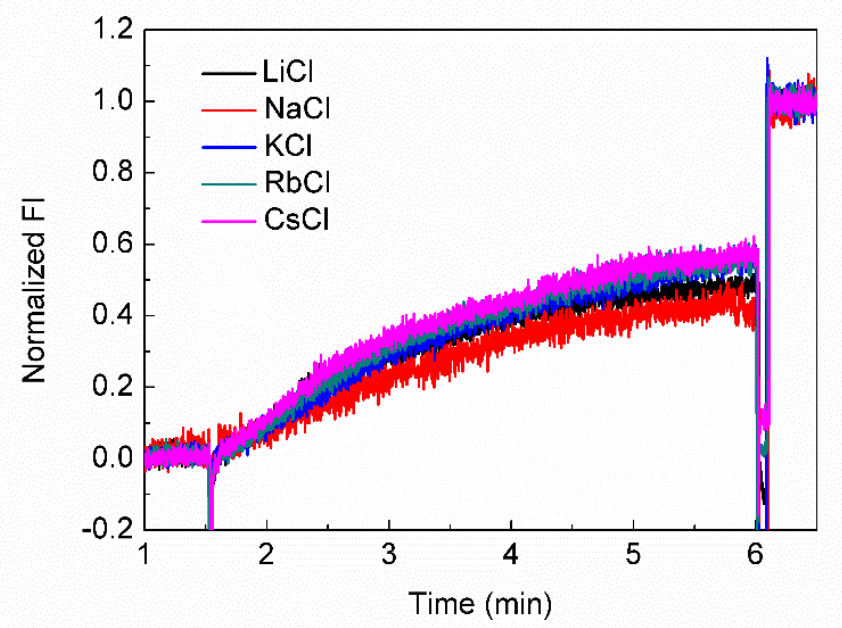

Figure S 67. Cation transport activity of $7(10 \mathrm{nM})$ across POPC-LUVs different extravesicular solution conditions. 7 was added at $1.5 \mathrm{~min}$. Inside: $100 \mathrm{mM} \mathrm{NaCl}, 1$ mM HPTS, 10 mM HEPES, pH 6.7; outside: 100 mM MCl ( $\mathrm{M}=\mathrm{Li}, \mathrm{Na}, \mathrm{K}), 10 \mathrm{mM}$ HEPES, $\mathrm{pH}$ 7.5 .

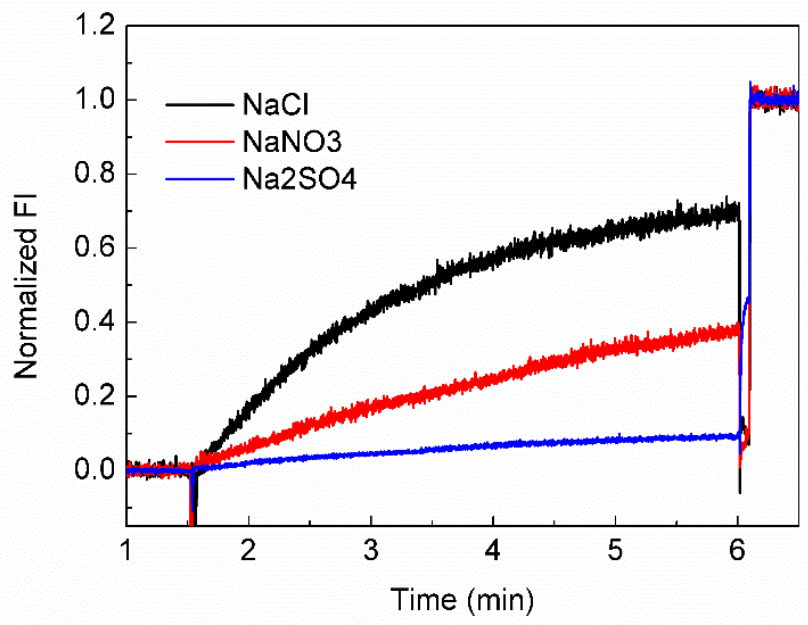

Figure S 68. Anion transport activity of $7(10 \mathrm{nM})$ across POPC-LUVs different buffer solution conditions. 7 was added at $1.5 \mathrm{~min}$. Inside: $100 \mathrm{mM} \mathrm{NaX,1 \textrm {mM }}$ HPTS, 10 mM HEPES, pH 6.7; outside: $100 \mathrm{mM} \mathrm{NaX,} 10 \mathrm{mM} \mathrm{HEPES,} \mathrm{pH} \mathrm{7.5.} \mathrm{X}=\mathrm{Cl}, \mathrm{NO}_{3}$, $\mathrm{SO}_{4}$. 


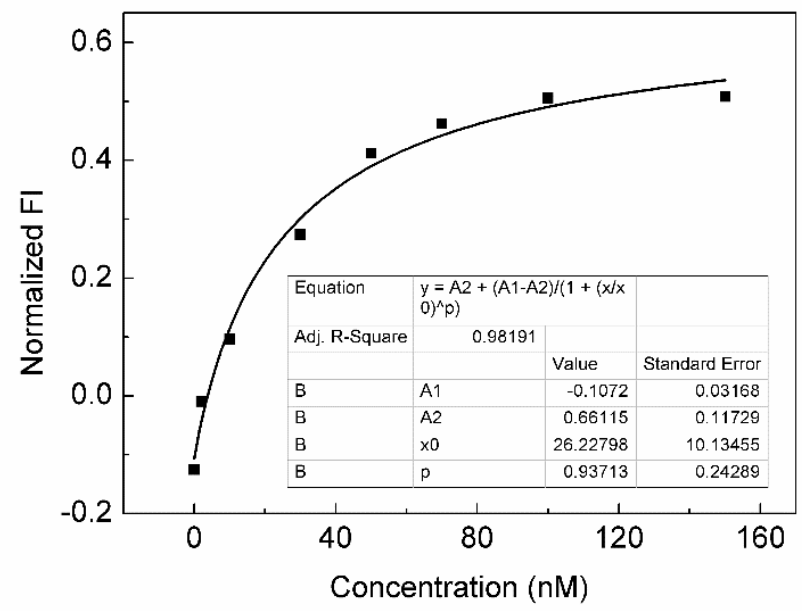

Figure S 69. Change of the normalized fluorescence intensity of HPTS from $1.5 \mathrm{~min}$ to $6 \mathrm{~min}$ as a function of $\mathbf{5}$ concentrations across POPC-LUVs $D H P T S$. EC $C_{50}$ value for $\mathbf{5}$ gained from the Hill plot was given in the inset table $(x 0)$.

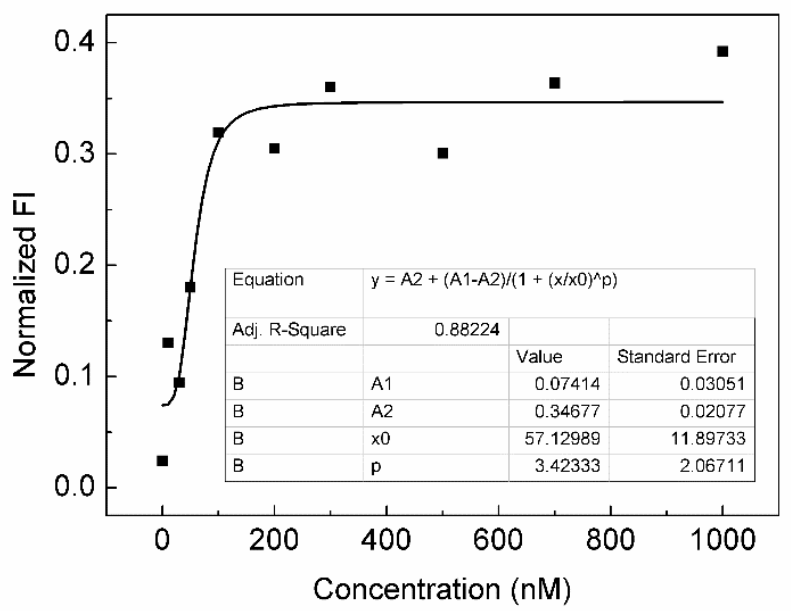

Figure S 70. Change of the normalized fluorescence intensity of HPTS from 1.5 min to 6 min as a function of $\mathbf{4}$ concentrations across POPC-LUVs $\supset$ HPTS. EC $C_{50}$ value for $\mathbf{4}$ gained from the Hill plot was given in the inset table $(\mathrm{x} 0)$. 


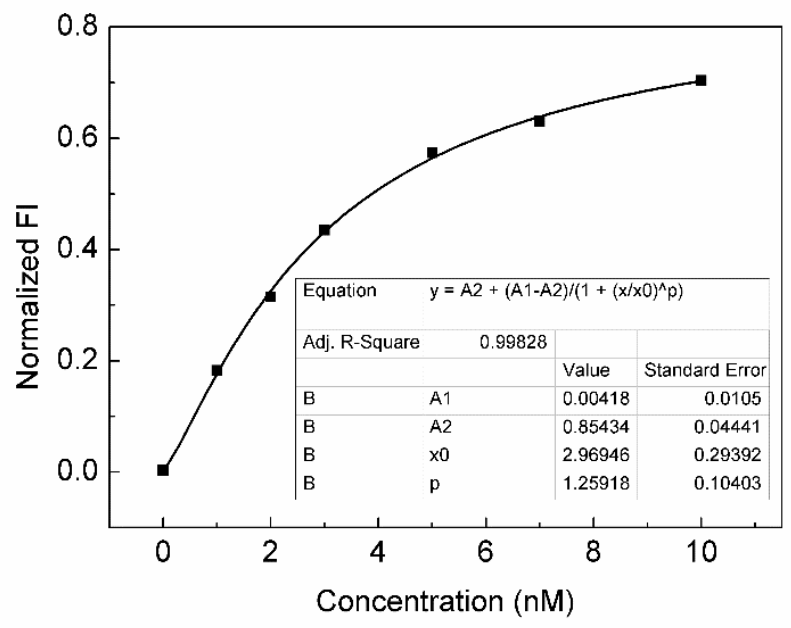

Figure S 71. Change of the normalized fluorescence intensity of HPTS from $1.5 \mathrm{~min}$ to $6 \mathrm{~min}$ as a function of $\mathbf{3}$ concentrations across POPC-LUVs $\supset$ HPTS. EC $C_{50}$ value for $\mathbf{3}$ gained from the Hill plot was given in the inset table $(x 0)$.

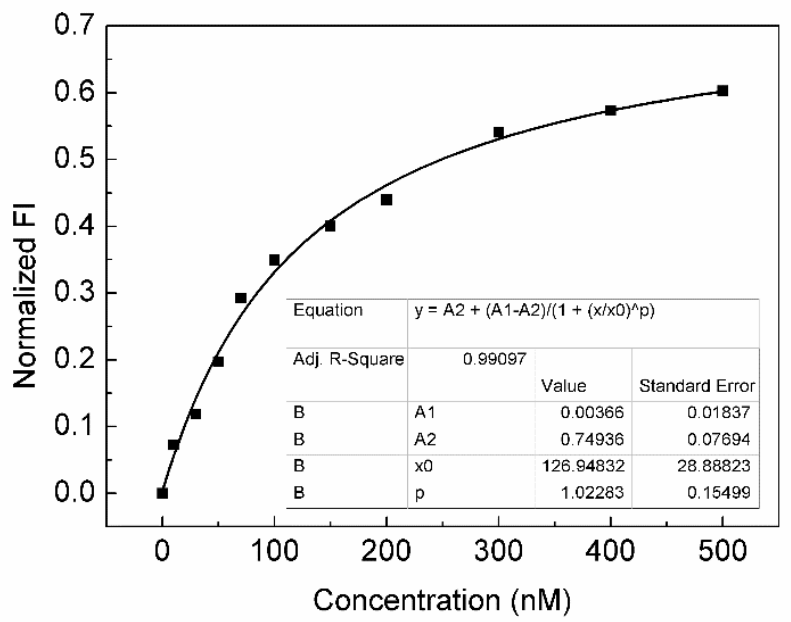

Figure S 72. Change of the normalized fluorescence intensity of HPTS from $1.5 \mathrm{~min}$ to $6 \mathrm{~min}$ as a function of 2 concentrations across POPC-LUVs $\supset$ HPTS. EC $C_{50}$ value for 2 gained from the Hill plot was given in the inset table $(\mathrm{x} 0)$. 


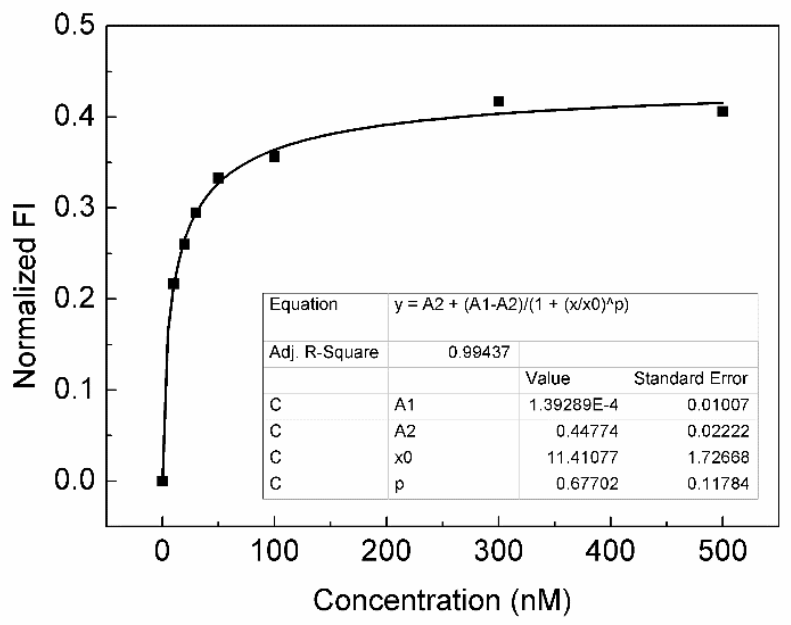

Figure S 73. Change of the normalized fluorescence intensity of HPTS from $1.5 \mathrm{~min}$ to $6 \mathrm{~min}$ as a function of 10 concentrations across POPC-LUVs $\supset$ HPTS. EC $C_{50}$ value for 10 gained from the Hill plot was given in the inset table $(\mathrm{x} 0)$.

Table S 12. Table of EC50 data for different anion carriers based on HPTS assay.

\begin{tabular}{|c|c|c|c|c|c|c|c|}
\hline & $\mathbf{7}$ & $\mathbf{5}$ & $\mathbf{4}$ & $\mathbf{3}$ & $\mathbf{2}$ & $\mathbf{1 0}$ & $\mathbf{9}^{*}$ \\
\hline$E C_{50} / \mathrm{nM}$ & 0.346 & 26.2 & 57.1 & 2.97 & 127 & 11.4 & $\backslash$ \\
\hline $\mathrm{n}$ & 1.35 & 0.937 & 3.42 & 1.26 & 1.02 & 0.677 & $\backslash$ \\
\hline
\end{tabular}

* 9 is too difficult to induce obvious ion transport across the membrane. 


\section{References}

[1] A. J. Plajer, J. Zhu, P. Proehm, A. D. Bond, U. F. Keyser, D. S. Wright, J. Am. Chem. Soc. 2019, 141, 8807-8815.

[2] A. J. Plajer, F. J. Rizzuto, H.-C. Niu, S. ,J. M. Goodman, D. S. Wright, Angew. Chem. Int. Ed. 2019, 58, 10655-10659.

[3] Bruker, SAINT, Bruker ASX Inc., Madison, Wisconsin, USA, 2012.

[4] Bruker, SADABS, Bruker AXS, Inc., Madison, Wisconsin, USA, 2001.

[5] L. Farrugia, J. Applied Cryst. 2012, 45, 849-854.

[6] G. M. Sheldrick, Acta Crystallogr. Sect. A 2015, 71, 3-8.

[7] TURBOMOLE GmbH, TURBOMOLE V7.3. a development of University of Karlsruhe and Forschungszentrum Karlsruhe $\mathrm{GmbH}, 2018$.

[8] A. D. Becke, Phys. Rev. A 1988, 38, 3098.

[9] C. Lee, W. Yang, R. G. Parr, Phys. Rev. B 1988, 37, 785.

[10] F. Weigend, M. Häser, H. Patzelt, R. Ahlrichs, Chem. Phys. Lett. 1998, 294, 143.

[11] F. Weigend, R. Ahlrichs, Phys. Chem. Chem. Phys. 2005, 7, 3297.

[12] D. Andrae, U. Häussermann, M. Dolg, H. Stoll, H. Preu, Theoret. Chim. Acta 1990, $77,123$.

[13] S. Grimme, J. Antony, S. Ehrlich, H. Krieg, J. Chem. Phys. 2010, 132, 154104.

[14] S. Grimme, S. Ehrlich, L. Goerigk, J. Comput. Chem. 2011, 32, 1456.

[15] R.F.W. Bader in Encyclopedia of Computational Chem, Vol 1, (P. v. Schleyer Eds: John Wiley and Sons) Chichester, 1998, 64-86.

[16] E. D. Glendening, J. K. Badenhoop, A. E. Reed, J. E. Carpenter, J. A. Bohmann, C. M. Morales, P. Karafiloglou, C. R. Landis, and F. Weinhold, NBO 7.0, Theoretical Chemistry Institute, University of Wisconsin, Madison, WI, 2018.

[17] M. J. Frisch, G. W. Trucks, H. B. Schlegel, G. E. Scuseria, M. A. Robb, J. R. Cheeseman, G. Scalmani, V. Barone, G. A. Petersson, H. Nakatsuji, X. Li, M.

Caricato, A. V. Marenich, J. Bloino, B. G. Janesko, R. Gomperts, B. Mennucci, H. P. Hratchian, J. V. Ortiz, A. F. Izmaylov, J. L. Sonnenberg, D. Williams-Young, F. Ding, F. Lipparini, F. Egidi, J. Goings, B. Peng, A. Petrone, T. Henderson, D. Ranasinghe, V. G. Zakrzewski, J. Gao, N. Rega, G. Zheng, W. Liang, M. Hada, M. Ehara, K. Toyota, R. Fukuda, J. Hasegawa, M. Ishida, T. Nakajima, Y. Honda, O. Kitao, H. Nakai, T. Vreven, K. Throssell, J. A. Montgomery, Jr., J. E. Peralta, F. Ogliaro, M. J. Bearpark, J. J. Heyd, E. N. Brothers, K. N. Kudin, V. N. Staroverov, T. A. Keith, R. Kobayashi, J. Normand, K. Raghavachari, A. P. Rendell, J. C. Burant, S. S. Iyengar, J. Tomasi, M. Cossi, J. M. Millam, M. Klene, C. Adamo, R. Cammi, J. W. Ochterski, R. L. Martin, K. Morokuma, O. Farkas, J. B. Foresman, and D. J. Fox, Gaussian 16, Gaussian, Inc., Wallingford CT, 2016.

[18] Humphrey, W., Dalke, A. and Schulten, K., J. Molec. Graphics 1996, 14, 33. 


\section{Appendix}

Optimised xyz coordinates and total energy [Hartree] of free ligand 1 in exo-exo conformation.

54
Energy $=-1713.886893189$
P $\quad 1.1153587 \quad-0.7350675 \quad-0.8262247$
$P \quad-0.3235683 \quad-0.7461353 \quad 1.3450872$
C $\quad-2.0978691 \quad 1.0457040 \quad 2.5075240$
N $\quad-0.4786138-1.2019542-0.3113706$
$N \quad-1.5069497 \quad 0.5113056 \quad 1.3816090$
$\begin{array}{llll}N & 1.1127909 & 0.0150215 & 0.7272115\end{array}$
C $\quad 1.1185424 \quad 2.0430993 \quad-3.7773676$
$\begin{array}{llll}N & 0.8694447 & 0.6721485 & -1.7968389\end{array}$
H $\quad 0.5446391 \quad 1.5014509 \quad-1.3223814$
$\begin{array}{llll}N & -1.5578769 & 0.7303868 & 3.6876432\end{array}$
C $\quad \begin{array}{lll}1.1178682 & 0.7851494 & -3.1488737\end{array}$
C $\quad-2.1216355 \quad 1.2215749 \quad 4.7912977$
H $\quad-1.6537472 \quad 0.9328012 \quad 5.7260969$
C $\quad-3.2181291 \quad 1.8887698 \quad 2.3997855$
C $\quad-3.7745845 \quad 2.4006059 \quad 3.5545053$
H $\quad-4.6359288 \quad 3.0533152 \quad 3.4967794$
C $\quad-3.2229289 \quad 2.0624297 \quad 4.7890513$
H $\quad-3.6301759 \quad 2.4416110 \quad 5.7149367$
C $\quad 2.2986663 \quad 0.3518173 \quad 1.5336656$
C $\quad-1.2216769-2.3643766 \quad-0.8281992$
N $\quad \begin{array}{llll}1.3489384 & -0.3448282 & -3.8223303\end{array}$
C $\quad 1.3666220 \quad 2.1048826 \quad-5.1337930$
H $\quad 1.3685624 \quad 3.0612770 \quad-5.6404753$
C $\quad 1.6045098 \quad-0.2606883 \quad-5.1279560$ 

H $\quad 1.7935940 \quad-1.2027024 \quad-5.6309810$
C $\quad \begin{array}{llll}1.6208723 & 0.9291597 & -5.8380016\end{array}$
H $1.8213318 \quad 0.9362896 \quad-6.8994573$
C $\quad 3.2777426 \quad 1.1294326 \quad 0.6514207$
H $\quad 4.1607684 \quad 1.4078116 \quad 1.2272352$
$\begin{array}{llll}H & 3.6060464 & 0.5299840 & -0.1991812\end{array}$
H $\quad 2.8138174 \quad 2.0382305 \quad 0.2679199$
C $\quad-0.5118667 \quad-3.6755326 \quad-0.4618778$
H $\quad-1.0622061 \quad-4.5375612 \quad-0.8421393$
H $\quad 0.4919252 \quad-3.6967315 \quad-0.8872625$
H $\quad-0.4283513 \quad-3.7741696 \quad 0.6214287$
C $\quad 2.9754800 \quad-0.9174116 \quad 2.0699329$
$\begin{array}{llll}H & 3.8549132 & -0.6691467 & 2.6660427\end{array}$
$\begin{array}{llll}H & 2.2849667 & -1.4804311 & 2.6984716\end{array}$
H $\quad 3.2911339-1.5586649 \quad 1.2457670$
C $\quad 1.8345205 \quad 1.2322000 \quad 2.6960925$
H $\quad 2.6820974 \quad 1.5051295 \quad 3.3257256$
H $1.3705895 \quad 2.1443629 \quad 2.3201763$
H $\quad 1.0991843 \quad 0.7175006 \quad 3.3157569$
C $\quad-1.3096116 \quad-2.2206706 \quad-2.3494154$
H $\quad-1.8505071 \quad-3.0650391 \quad-2.7784156$
$\begin{array}{llll}H & -1.8310062 & -1.3005828 & -2.6147958\end{array}$
H $\quad-0.3184771 \quad-2.1825289 \quad-2.8032152$
C $\quad-2.6272313 \quad-2.3480645 \quad-0.2227724$
H $\quad-3.2072052 \quad-3.1906136 \quad-0.6005234$
H $\quad-2.5908761 \quad-2.4257136 \quad 0.8651012$
H $\quad-3.1482526 \quad-1.4258516 \quad-0.4805442$
$\begin{array}{llll}H & 0.9326614 & 2.9393306 & -3.2004134\end{array}$ 

H $\quad-3.6329511 \quad 2.1200164 \quad 1.4276879$
$H \quad-1.8153609 \quad 0.8716677 \quad 0.4908542$

Optimised xyz coordinates and total energy [Hartree] of free ligand 1 in endo-exo conformation.

\section{4}
Energy $=-1713.897132668$
P $\quad-1.5482493 \quad 0.2873746 \quad 0.1819026$
P $\quad 0.0925721 \quad 1.4355296 \quad 1.8576224$
N $\quad-0.1944479-2.1012386-2.6395863$
N $\quad-0.7207330 \quad-0.8226082 \quad-0.8041391$
N $\quad 1.7791249 \quad 1.0135867 \quad 1.7542400$
N $\quad 2.0311115 \quad-0.4374230-0.0730086$
$\begin{array}{llll}N & -0.8446034 & 0.0136315 & 1.7294704\end{array}$
$\begin{array}{llll}N & -0.4613762 & 1.6368027 & 0.2502077\end{array}$
C $\quad-1.1510031 \quad-1.4873879-1.9296085$
C $\quad-0.9847985 \quad-1.1241601 \quad 2.6413383$
C $\quad-2.5046564 \quad-1.5344110-2.3116083$
$\begin{array}{llll}\text { C } & 2.5910721 & 0.3303791 & 0.8604933\end{array}$
C $\quad-2.8457233 \quad-2.2298947 \quad-3.4531645$
$\begin{array}{llll}\text { C } & 4.1987829 & -1.0231045 & -0.9083638\end{array}$
$\begin{array}{llll}\text { C } & 4.7894990 & -0.2251840 & 0.0700984\end{array}$
C $\quad-0.5320263 \quad 2.8706411 \quad-0.5392123$
C $2.8178832 \quad-1.0897508-0.9351840$
C $\quad-0.5505222 \quad-2.7708661 \quad-3.7365050$
$\begin{array}{llll}\text { C } & 0.1274286 & -2.1482906 & 2.3687768\end{array}$
$\begin{array}{llll}\text { C } & 3.9885016 & 0.4602834 & 0.9594588\end{array}$
C $\quad-2.3525126 \quad-1.7736937 \quad 2.4134657$
C $\quad 0.8070404 \quad 3.6019113 \quad-0.4075580$ 

$\begin{array}{llll}\text { C } & -0.8903196 & -0.6249347 & 4.0857740\end{array}$
C $\quad-1.8536325 \quad-2.8699563 \quad-4.1949438$
$\begin{array}{llll}\text { C } & -1.6753517 & 3.7698410 & -0.0505408\end{array}$
C $\quad-0.7554609 \quad 2.4785506 \quad-2.0030390$
$\begin{array}{llll}\text { H } & 5.8662269 & -0.1366368 & 0.1332481\end{array}$
$\begin{array}{llll}\text { H } & 0.9961654 & 3.8886611 & 0.6282476\end{array}$
$\begin{array}{llll}H & 2.3060635 & 1.5331391 & 2.4400837\end{array}$
$\begin{array}{llll}\text { H } & 1.6246295 & 2.9637224 & -0.7421028\end{array}$
$\begin{array}{llll}\text { H } & -2.6297926 & 3.2484822 & -0.1330829\end{array}$
H $\quad 0.0740152 \quad-0.1513406 \quad 4.2760557$
H $\quad-3.2521435 \quad-1.0327200 \quad-1.7146063$
H $\quad-3.8811486-2.2779895 \quad-3.7652432$
H $\quad 0.2581946 \quad-3.2523587 \quad-4.2755820$
H $4.4197021 \quad 1.0935838 \quad 1.7234550$
H $\quad 0.8019758 \quad 4.5101394 \quad-1.0109341$
$\begin{array}{llll}H & -1.5244903 & 4.0417110 & 0.9949637\end{array}$
H $\quad-1.7340315 \quad 4.6870683 \quad-0.6390365$
$\begin{array}{llll}H & -0.7809007 & 3.3678203 & -2.6335942\end{array}$
$\begin{array}{llll}\text { H } & -2.4820307 & -2.6182466 & 3.0905935\end{array}$
H $\quad 0.0798283 \quad-2.4948783 \quad 1.3379303$
$\begin{array}{llll}\text { H } & 0.0433237 & 1.8229922 & -2.3482266\end{array}$
H $\quad-3.1552986 \quad-1.0577734 \quad 2.5898446$
H $2.2916828 \quad-1.6855141 \quad-1.6734590$
H $\quad-2.4447055-2.1472222 \quad 1.3926358$
$\begin{array}{llll}\text { H } & 1.1068208 & -1.6980827 & 2.5255751\end{array}$
H $\quad 0.2921821 \quad-0.8301163 \quad-0.6424811$
H $\quad 0.0314151 \quad-3.0089555 \quad 3.0331370$
H $4.7902357 \quad-1.5730303 \quad-1.6252192$ 

$\begin{array}{llll}H & -1.6731569 & 0.1044313 & 4.2938637\end{array}$
$\begin{array}{llll}\text { H } & -2.0838852 & -3.4247649 & -5.0927264\end{array}$
H $\quad-1.7036003 \quad 1.9523700 \quad-2.1285799$
H $\quad-0.9948765 \quad-1.4601185 \quad 4.7788541$

Optimised xyz coordinates and total energy [Hartree] of free ligand 1 in endo-endo conformation.

54

Energy $=-1713.880474933$

P $\quad 1.2838958-1.5560601-0.6512023$

P $\quad 0.1438115-1.3123644 \quad 1.6641749$

$\begin{array}{llll}N & -1.9902973 & 0.6394901 & -0.0217998\end{array}$

$N \quad-0.2323676 \quad-1.8826608 \quad 0.1032921$

$\begin{array}{llll}N & -0.9381387 & 0.0006665 & 1.9731773\end{array}$

H $\quad-0.9704977 \quad 0.1956698 \quad 2.9627993$

$\begin{array}{llll}\text { N } & 1.5375366 & -0.7414198 & 0.8235505\end{array}$

C $\quad 0.3924380 \quad 3.0205302 \quad-0.8889001$

N $\quad \begin{array}{llll}1.0928479 & -0.3301937 & -1.8559728\end{array}$

C $\quad \begin{array}{llll}-1.6035974 & 0.9581554 & 1.2127913\end{array}$

$\begin{array}{llll}N & 0.7853701 & 1.7505822 & -0.8203679\end{array}$

C $\quad-1.9002844 \quad 2.2066910 \quad 1.7849292$

H $\quad-1.5518709 \quad 2.4412637 \quad 2.7820484$

C $\quad-2.6743646 \quad 1.5418270 \quad-0.7215984$

H $\quad-2.9488729 \quad 1.2448603 \quad-1.7276555$

C $\quad-3.0344068 \quad 2.7892444 \quad-0.2376499$

H $\quad-3.5965760 \quad 3.4776651 \quad-0.8513130$

C $\quad-2.6323222 \quad 3.1200483 \quad 1.0528739$

H $\quad-2.8746564 \quad 4.0860546 \quad 1.4763715$

C $\quad 2.7842774 \quad-0.2294527 \quad 1.4037944$ 

C $\quad-1.2461855 \quad-2.8587674 \quad-0.3121907$
C $\quad 0.6306374 \quad 0.9821264 \quad-1.8977604$
C $\quad-0.1475830 \quad 3.6058628 \quad-2.0227602$
H $\quad-0.4426521 \quad 4.6448532 \quad-2.0197724$
C $\quad 0.0712704 \quad 1.4766134 \quad-3.0881493$
H $\quad-0.0605893 \quad 0.8194667 \quad-3.9375264$
C $\quad-0.3069035 \quad 2.8030349 \quad-3.1482397$
H $\quad-0.7352435 \quad 3.2048401 \quad-4.0572698$
C $\quad 3.6921593 \quad 0.2585232 \quad 0.2729423$
$\begin{array}{llll}H & 4.6176462 & 0.6577117 & 0.6890952\end{array}$
H $\quad 3.9536856 \quad-0.5602091 \quad-0.3992962$
H $3.1946612 \quad 1.0372348 \quad-0.3006033$
C $\quad-0.6910982 \quad-4.2863865 \quad-0.2159494$
H $\quad-1.4376172 \quad-5.0171118 \quad-0.5323526$
H $\quad 0.1903038 \quad-4.4007028 \quad-0.8477548$
H $\quad-0.4039882 \quad-4.5116279 \quad 0.8121641$

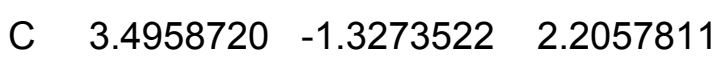
H $4.4205656 \quad-0.9505813 \quad 2.6463226$
H $2.8567673 \quad-1.6934331 \quad 3.0098111$
$\begin{array}{llll}H & 3.7421202 & -2.1692756 & 1.5572791\end{array}$
C $\quad 2.4307827 \quad 0.9523486 \quad 2.3128564$
H $3.3361862 \quad 1.3999515 \quad 2.7244691$
H $1.8838178 \quad 1.7004440 \quad 1.7419592$
H $\quad 1.8092044 \quad 0.6280426 \quad 3.1493625$
C $\quad-1.6460947-2.5378646 \quad-1.7563434$
H $\quad-2.4392084 \quad-3.2084220-2.0896120$
H $\quad-1.9926387 \quad-1.5078455 \quad-1.8186331$
H $\quad-0.7982514 \quad-2.6624397 \quad-2.4324680$ 

C $\quad-2.4708936 \quad-2.7155539 \quad 0.5940998$
H $\quad-3.2406658 \quad-3.4250852 \quad 0.2888142$
H $\quad-2.2149214 \quad-2.9268393 \quad 1.6336162$
H $\quad-2.8710863 \quad-1.7062326 \quad 0.5304200$
H $1.2282198 \quad-0.7258450 \quad-2.7744036$
H $\quad 0.5197964 \quad 3.5999243 \quad 0.0187491$

Optimised xyz coordinates and total energy [Hartree] of free ligand $\mathbf{2}$ in exo-exo conformation.

56
Energy $=-6516.881448506$
Se $\quad 2.5430014 \quad-2.0266957 \quad-1.5559987$
Se $\quad-0.3523053 \quad-2.0320639 \quad 2.9632839$
P $\quad 1.1045793 \quad-0.7462971-0.7828073$
P $\quad-0.2896166 \quad-0.7775995 \quad 1.3113176$
C $\quad-2.1081287 \quad 1.0665310 \quad 2.3582525$
N $\quad-0.4040423 \quad-1.3442397 \quad-0.2810896$
N $\quad-1.4816264 \quad 0.4217304 \quad 1.2932520$
N $\quad 1.1825773 \quad-0.1117103 \quad 0.7863074$
$\begin{array}{llll}\text { C } & 1.4405570 & 2.1644468 & -3.4878287\end{array}$
N $\quad 0.8716863 \quad 0.6714766 \quad-1.6749610$
H $\quad 0.8271823 \quad 1.4958630 \quad-1.0976233$
$\begin{array}{llll}N & -1.4049292 & 1.2417544 & 3.4705009\end{array}$
$\begin{array}{llll}\text { C } & 1.0419444 & 0.8979565 & -3.0400174\end{array}$
C $\quad-1.9943181 \quad 1.8544429 \quad 4.4970647$
H $\quad-1.3900394 \quad 1.9640506 \quad 5.3903757$
C $\quad-3.4270356 \quad 1.5179934 \quad 2.2158523$
C $\quad-4.0144719 \quad 2.1740434 \quad 3.2810811$
H $\quad-5.0310618 \quad 2.5355605 \quad 3.2014987$ 

C $\quad-3.2898032 \quad 2.3456791 \quad 4.4574262$
$\begin{array}{llll}H & -3.7158972 & 2.8450444 & 5.3153747\end{array}$
C $\quad 2.3587729 \quad 0.3893362 \quad 1.5495461$
C $\quad-1.2723519-2.4117252 \quad-0.8494890$
N $\quad 0.7951890 \quad-0.1115231 \quad-3.8661025$
C $\quad 1.5794112 \quad 2.3656563 \quad-4.8482649$
H $\quad 1.8846153 \quad 3.3327204 \quad-5.2253509$
C $\quad 0.9582932 \quad 0.0916887 \quad-5.1733499$
H $\quad 0.7609655 \quad-0.7624156 \quad-5.8111783$
C $\quad 1.3403543 \quad 1.3068759 \quad-5.7201031$
H $1.4464802 \quad 1.4207991 \quad-6.7891562$
C $3.2195895 \quad 1.2359180 \quad 0.6082350$
H $4.0941302 \quad 1.5924652 \quad 1.1514540$
H $\quad 3.5662854 \quad 0.6596937 \quad-0.2487025$
H $2.6708322 \quad 2.1081885 \quad 0.2498503$
C $\quad-0.7021343 \quad-3.7918656 \quad-0.5061909$
H $\quad-1.3411525 \quad-4.5706350 \quad-0.9245731$
H $\quad 0.2988588 \quad-3.9031986 \quad-0.9179495$
H $\quad-0.6478835 \quad-3.9256524 \quad 0.5727524$
C $\quad 3.1752608 \quad-0.7884425 \quad 2.0909794$
H $\quad 4.0361998 \quad-0.4164177 \quad 2.6477739$
H $2.5675412 \quad-1.3993865 \quad 2.7551631$
H $3.5301551 \quad-1.4149366 \quad 1.2747202$
C $\quad 1.8479793 \quad 1.2619982 \quad 2.6941727$
H $\quad 2.6977216 \quad 1.6560456 \quad 3.2520116$
H $1.2621162 \quad 2.0991205 \quad 2.3149272$
H $\quad 1.21512620 .7000448 \quad 3.3768559$
C $\quad-1.3378016 \quad-2.2173199 \quad-2.3632603$ 

H $\quad-1.9868208 \quad-2.9793298 \quad-2.7955050$
H $\quad-1.7390463-1.2353330-2.6139372$
H $\quad-0.3551256-2.2981076-2.8219548$
C $\quad-2.6750649-2.2610665 \quad-0.2543602$
H $\quad-3.3139097 \quad-3.0513234 \quad-0.6474173$
H $\quad-2.6634315 \quad-2.3454328 \quad 0.8316706$
H $\quad-3.1203419-1.3039009 \quad-0.5305376$
H $\quad 1.6460741 \quad 2.9557981 \quad-2.7793865$
H $\quad-3.9699880 \quad 1.3411438 \quad 1.2970405$
H $\quad-1.9351519 \quad 0.5125530 \quad 0.3983554$

Optimised xyz coordinates and total energy [Hartree] of free ligand 2 in endo-exo conformation.

56

Energy $=-6516.909012621$

Se $\quad 2.1879652 \quad-2.3750208-1.4990616$

Se $\quad 0.2282870 \quad-2.6728601 \quad 3.3157266$

P $\quad 0.8360912-1.1097952 \quad-0.5458651$

P $\quad-0.0769681 \quad-1.2799945 \quad 1.7878420$

$\begin{array}{llll}N & -1.3661504 & 1.4138068 & 0.6518236\end{array}$

$\begin{array}{llll}N & -0.5297119 & -1.7425531 & 0.2365760\end{array}$

$\begin{array}{llll}N & -1.1639958 & -0.1456162 & 2.3967237\end{array}$

H $\quad-1.4300846 \quad-0.3666623 \quad 3.3434418$

N $\quad 1.1963205 \quad-0.5206123 \quad 1.0101476$

$\begin{array}{llll}N & 0.0884912 & 2.1154564 & -2.6013528\end{array}$

N $\quad 0.2454530 \quad 0.1746419 \quad-1.4129534$

H $\quad-0.3935165 \quad 0.7027655 \quad-0.8005396$

C $\quad-1.6718863 \quad 1.0456140 \quad 1.8941126$

C $\quad 0.6385078 \quad 0.8976099 \quad-2.5360712$ 

C $\quad-2.4910902 \quad 1.8291383 \quad 2.7221554$
H $\quad-2.7200903 \quad 1.4998303 \quad 3.7264522$
C $\quad-1.8489556 \quad 2.5748354 \quad 0.1887799$
$\begin{array}{llll}H & -1.5476046 & 2.8213128 & -0.8227695\end{array}$
$\begin{array}{llll}\text { C } & -2.6610921 & 3.4103937 & 0.9323621\end{array}$
H $\quad-3.0241816 \quad 4.3367906 \quad 0.5127732$
C $\quad-2.9878887 \quad 3.0180163 \quad 2.2290528$
$\begin{array}{llll}H & -3.6217551 & 3.6370411 & 2.8499769\end{array}$
C $\quad 2.3932146 \quad 0.1820628 \quad 1.5203653$
C $\quad-1.5541462 \quad-2.7039405-0.2341218$
C $\quad 1.5003675 \quad 0.4120020 \quad-3.5254828$
H $\quad 1.9153985 \quad-0.5783893 \quad-3.4421746$
C $\quad 0.3812697 \quad 2.8895379 \quad-3.6460720$
H $\quad-0.0911457 \quad 3.8654252 \quad-3.6567992$
C $\quad \begin{array}{lll}1.7960910 & 1.2364452 & -4.5952647\end{array}$
H $2.4621332 \quad 0.8841727 \quad-5.3720344$
C $\quad 1.2321204 \quad 2.5063523 \quad-4.6698170$
H $\quad 1.4410077 \quad 3.1739999 \quad-5.4930223$
C $2.8705505 \quad 1.1440516 \quad 0.4296590$
$\begin{array}{llll}H & 3.7435508 & 1.6906262 & 0.7853071\end{array}$
H $\quad 3.1580933 \quad 0.6058888 \quad-0.4740656$
H $2.0903190 \quad 1.8600825 \quad 0.1736707$
C $\quad-1.0250068-4.1365507 \quad-0.1169792$
H $\quad-1.7828957 \quad-4.8419264 \quad-0.4603934$
H $\quad-0.1296418-4.2635134 \quad-0.7231076$
H $\quad-0.7745347 \quad-4.3680441 \quad 0.9169666$
C $\quad 3.4856643 \quad-0.8341304 \quad 1.8646331$
H $4.3704223 \quad-0.3188346 \quad 2.2406599$ 

H $\quad 3.1331076-1.5272139 \quad 2.6271847$
H $\quad 3.7632139-1.4082502 \quad 0.9823140$
C $\quad \begin{array}{lll}1.9881623 & 0.9748107 & 2.7642602\end{array}$
H $\quad 2.8533932 \quad 1.5162771 \quad 3.1457628$
H $\quad 1.2058256 \quad 1.6955180 \quad 2.5275902$
H $1.6314198 \quad 0.3123794 \quad 3.5529398$
C $\quad-1.8820477 \quad-2.3705967 \quad-1.6907717$
H $\quad-2.6521586 \quad-3.0522662 \quad-2.0511694$
H $\quad-2.2462509 \quad-1.3483233 \quad-1.7848319$
H $\quad-1.0055230 \quad-2.4850189 \quad-2.3284099$
$\begin{array}{llll}\text { C } & -2.8032237 & -2.5224739 & 0.6303675\end{array}$
H $\quad-3.5846819 \quad-3.1977444 \quad 0.2829623$

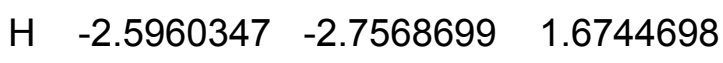
H $\quad-3.1741774 \quad-1.4996838 \quad 0.5660713$

Optimised xyz coordinates and total energy [Hartree] of free ligand 2 in endo-endo conformation.

56
Energy $=-6516.895376192$
Se $2.3699416 \quad-2.9219166 \quad-1.5053397$
Se $\quad 0.2617818 \quad-2.3343292 \quad 3.3075627$
P $\quad 1.1825931-1.4132778 \quad-0.6763625$
P $\quad 0.1113743-1.1837540 \quad 1.5681876$
$\begin{array}{llll}N & -1.9600877 & 0.7074428 & -0.0882478\end{array}$
$\begin{array}{llll}\text { N } & -0.2805121 & -1.8235007 & 0.0719608\end{array}$
$\begin{array}{llll}N & -0.9261381 & 0.0868756 & 1.9291349\end{array}$
H $\quad-0.9996253 \quad 0.2123910 \quad 2.9267902$
N $\quad 1.5228942 \quad-0.6705607 \quad 0.7846018$
C $\quad 0.3452494 \quad 3.0924439 \quad-0.8201543$ 

N $\quad 0.9932944 \quad-0.2495465 \quad-1.8729419$
C $\quad-1.6461458 \quad 1.0093043 \quad 1.1663746$
$\begin{array}{llll}\text { N } & 0.6905712 & 1.8066762 & -0.7741821\end{array}$
C $\quad-2.0550497 \quad 2.2038256 \quad 1.7763541$
$\begin{array}{llll}H & -1.7662529 & 2.4210202 & 2.7957920\end{array}$
C $\quad-2.6849158 \quad 1.5811060 \quad-0.7852360$
$\begin{array}{llll}H & -2.9027698 & 1.2988037 & -1.8088677\end{array}$
C $\quad-3.1467826 \quad 2.7819522 \quad-0.2726251$
H $\quad-3.7334274 \quad 3.4524004 \quad-0.8832488$
C $\quad-2.8206793 \quad 3.0907949 \quad 1.0448508$
H $\quad-3.1503565 \quad 4.0190219 \quad 1.4924445$
C $\quad 2.7871015 \quad-0.1064385 \quad 1.3200176$
C $\quad-1.3562342 \quad-2.7624697 \quad-0.3335388$
C $\quad 0.5913613 \quad 1.0880622 \quad-1.8865800$
C $\quad-0.0970928 \quad 3.7312286 \quad-1.9666606$
H $\quad-0.3618041 \quad 4.7781782 \quad-1.9467719$
C $\quad 0.1437485 \quad 1.6363462 \quad-3.0972127$
H $\quad 0.0616252 \quad 1.0149326 \quad-3.9786827$
C $\quad-0.1942062 \quad 2.9752560 \quad-3.1314275$
H $\quad-0.5405451 \quad 3.4230384 \quad-4.0534965$
C $\quad 3.5798674 \quad 0.5066441 \quad 0.1642176$
H $4.5086545 \quad 0.9209560 \quad 0.5559808$
H $\quad 3.8376496-0.2483000 \quad-0.5783176$
H $\quad 3.0132174 \quad 1.3010931 \quad-0.3134935$
C $\quad-0.8970696 \quad-4.2073958 \quad-0.1149119$
H $\quad-1.6937152 \quad-4.8942820 \quad-0.4044550$
H $\quad-0.0108490 \quad-4.4291806 \quad-0.7054013$
H $\quad-0.6599753 \quad-4.3727419 \quad 0.9354627$ 

C $\quad 3.6130183 \quad-1.2135643 \quad 1.9819363$
$\begin{array}{llll}H & 4.5465965 & -0.7975076 & 2.3631481\end{array}$
H $\quad 3.0682547 \quad-1.6672097 \quad 2.8068020$
$\begin{array}{llll}\text { H } & 3.8493067 & -1.9917904 & 1.2572021\end{array}$
C $\quad 2.4164974 \quad 0.9824320 \quad 2.3280093$
H $\quad 3.3232810 \quad 1.4521806 \quad 2.7086776$
H $1.7979431 \quad 1.7397245 \quad 1.8486607$
H $\quad 1.8757602 \quad 0.5620516 \quad 3.1766170$
C $\quad-1.6668842 \quad-2.5004437 \quad-1.8081363$
H $\quad-2.4868841 \quad-3.1429290 \quad-2.1288234$
H $\quad-1.9544321 \quad-1.4597041 \quad-1.9502189$
$\begin{array}{llll}\text { H } & -0.8028182 & -2.7224953 & -2.4353748\end{array}$
C $\quad-2.5980254 \quad-2.4821189 \quad 0.5150493$
H $\quad-3.3891552 \quad-3.1707821 \quad 0.2187673$
H $\quad-2.3940319 \quad-2.6429098 \quad 1.5735529$
H $\quad-2.9439117 \quad-1.4627343 \quad 0.3672341$
H $\quad 1.2004155 \quad-0.6381868 \quad-2.7799167$
H $\quad 0.4283786 \quad 3.6338873 \quad 0.1152367$

Optimised xyz coordinates and total energy [Hartree] of complex 4.

72
Energy $=-2757.286125929$
C $\quad 3.2562261 \quad-4.2786798-3.5163735$
C $\quad \begin{array}{lll}1.9420364 & -4.1736660 & -3.1177937\end{array}$
N $\quad 1.4492196 \quad-3.1185959-2.4394155$
C $\quad 2.2963853 \quad-2.1140935 \quad-2.1336992$
C $\quad 3.6462221 \quad-2.1488258-2.5077041$
C $\quad 4.1274240 \quad-3.2364590-3.2035426$ 

$\begin{array}{llll}\text { Mo } & -0.7813887 & -2.9806168 & -1.8719408\end{array}$
$\begin{array}{llll}\text { C } & -1.2070858 & -2.0472106 & -3.6341980\end{array}$
$\begin{array}{llll}\text { O } & -1.5216265 & -1.6364284 & -4.6586247\end{array}$
$\begin{array}{llll}\text { N } & 1.7924432 & -1.0437529 & -1.4331209\end{array}$
$\begin{array}{llll}\text { P } & 0.1996897 & -0.9916833 & -0.7955450\end{array}$
$\begin{array}{llll}N & -0.2582665 & 0.6500535 & -0.8726361\end{array}$
C $\quad-0.8271605 \quad 1.4320607 \quad-1.9911304$
$\begin{array}{llll}\text { C } & 0.0184935 & 1.1706509 & -3.2401381\end{array}$
C $\quad-0.6135390 \quad-4.2651819 \quad-0.2895980$
$\begin{array}{llll}\text { O } & -0.6065818 & -5.0717000 & 0.5257884\end{array}$
$\begin{array}{llll}\text { C } & -2.6503787 & -2.6210312 & -1.3045017\end{array}$
$\begin{array}{llll}\text { O } & -3.7282172 & -2.3803572 & -0.9834706\end{array}$
$\begin{array}{llll}\text { C } & -1.3229984 & -4.6331198 & -2.8676068\end{array}$
$\begin{array}{llll}\text { O } & -1.6257116 & -5.5821561 & -3.4426626\end{array}$
$\begin{array}{llll}N & 0.4100708 & -0.5923301 & 0.8578940\end{array}$
C $\quad 0.7257961 \quad-1.4721764 \quad 2.0035926$
C $\quad \begin{array}{lll}1.7383326 & -2.5230157 & 1.5381432\end{array}$
$\begin{array}{llll}\text { P } & -0.3679554 & 0.9254266 & 0.8154820\end{array}$
$\begin{array}{llll}\text { N } & 0.8658502 & 2.0719109 & 1.1461179\end{array}$
$\begin{array}{llll}\text { C } & 0.6459879 & 3.2532927 & 1.8141774\end{array}$
$\begin{array}{llll}N & -0.5768005 & 3.4539308 & 2.3477597\end{array}$
C $\quad-0.7984925 \quad 4.6146876 \quad 2.9956408$
$\begin{array}{llll}\text { C } & 0.1522571 & 5.6001372 & 3.1436327\end{array}$
C $\quad 1.4159989 \quad 5.3873210 \quad 2.5952346$
C $\quad 1.6646128 \quad 4.2087763 \quad 1.9259521$
$\begin{array}{llll}\text { Mo } & -2.2008469 & 1.8240978 & 2.1978488\end{array}$
$\begin{array}{llll}\text { C } & -3.4181697 & 0.2730793 & 1.9583398\end{array}$
$\begin{array}{llll}\text { O } & -4.0972756 & -0.6450807 & 1.8223989\end{array}$ 

C $\quad-3.5058073 \quad 2.7595116 \quad 3.3969191$
$\begin{array}{llll}O & -4.2480658 & 3.3022383 & 4.0879235\end{array}$
C $\quad-1.5608527 \quad 0.9698772 \quad 3.9353242$
$\begin{array}{llll}\text { O } & -1.3261546 & 0.5259769 & 4.9673337\end{array}$
C $\quad-3.2292360 \quad 2.7788840 \quad 0.7104276$
O
C $\quad 1.3914151 \quad-0.6250405 \quad 3.0907278$
C $\quad-0.5486973 \quad-2.1372579 \quad 2.5285444$
C $\quad-2.2880364 \quad 1.0391649 \quad-2.2240499$
C $\quad-0.7111477 \quad 2.9201721 \quad-1.6461607$
$\begin{array}{llll}H & 1.7743217 & 1.9649231 & 0.7209787\end{array}$
H $\quad 2.4553661 \quad-0.3263586 \quad-1.1813018$
H $\quad-1.7886382 \quad 4.7350133 \quad 3.4060140$
H $2.6310903 \quad 4.0082012 \quad 1.4849541$
H $\quad-0.0909933 \quad 6.5076769 \quad 3.6748410$
H $\quad 1.6054598 \quad-1.2465532 \quad 3.9595597$
H $\quad 2.3295097 \quad-0.2051084 \quad 2.7264343$
H $\quad 0.7568831 \quad 0.1929044 \quad 3.4164466$
$\begin{array}{llll}H & 2.1927578 & 6.1336313 & 2.6894928\end{array}$
H $1.2322408 \quad-4.9545976 \quad-3.3405727$
H $\quad-0.3176546 \quad-2.8219716 \quad 3.3441839$
H $\quad-1.2496395 \quad-1.3926206 \quad 2.8949004$
H $\quad-1.0420425 \quad-2.6979836 \quad 1.7394194$
H $\quad 4.2912430 \quad-1.3221069 \quad-2.2445506$
H $\quad 1.9728478 \quad-3.1890960 \quad 2.3675100$
H $1.3544302 \quad-3.1297334 \quad 0.7228975$
H $2.6614930 \quad-2.0477909 \quad 1.2063751$
H $\quad 5.1669132 \quad-3.2768141 \quad-3.4988221$ 

H $\quad 3.5864784 \quad-5.1519962 \quad-4.0578422$
H $\quad-2.7266577 \quad 1.6416033 \quad-3.0192695$
H $\quad-2.3660426 \quad-0.0073899 \quad-2.5049233$
H $\quad-2.8735160 \quad 1.1852689-1.3203295$
H $\quad-1.1411416 \quad 3.5113771 \quad-2.4537582$
H $\quad-1.2413444 \quad 3.1717303 \quad-0.7318796$
H $\quad 0.3334357 \quad 3.2081795 \quad-1.5269252$
H $\quad-0.3982729 \quad 1.7174008 \quad-4.0854458$
H $\quad 1.0443606 \quad 1.5059622 \quad-3.0836460$
H $\quad 0.04182840 .1183588 \quad-3.5049151$

Optimised xyz coordinates and total energy [Hartree] of complex $\mathbf{5}$.

62
Energy $=-3082.336490578$
C $\quad-2.7415516 \quad-3.0720340 \quad 4.7452650$
C $\quad-2.1097428 \quad-1.8490763 \quad 4.6541084$
N $\quad-1.5839999 \quad-1.3892019 \quad 3.5059947$
C $\quad-1.6748070 \quad-2.1492795 \quad 2.3959621$
C $\quad-2.3009853 \quad-3.3990678 \quad 2.4139961$
$\begin{array}{llll}\text { C } & -2.8366299 & -3.8589758 & 3.6003978\end{array}$
$\begin{array}{llll}\text { Rh } & -0.5958911 & 0.5104175 & 3.3351521\end{array}$
C $\quad 0.2562139 \quad 2.1326561 \quad 3.1549664$
O $\quad 0.7799785 \quad 3.1417373 \quad 3.0668559$
N $\quad-1.1194361 \quad-1.6262541 \quad 1.2542423$
P $\quad-0.3623087 \quad-0.0870587 \quad 1.2651412$
$\begin{array}{llll}N & -0.8995500 & 0.6960718 & -0.1457642\end{array}$
C $\quad-2.0892750 \quad 1.5512999 \quad-0.3579066$
C $\quad-2.3540645 \quad 1.6264092-1.8625175$ 

$\begin{array}{llll}\text { Cl } & -0.9429899 & 0.9975755 & 5.6260516\end{array}$
$\begin{array}{llll}N & 1.0592023 & -0.2730999 & 0.3505088\end{array}$
$\begin{array}{llll}\text { C } & 2.4158684 & -0.6795716 & 0.7817982\end{array}$
$\begin{array}{llll}\text { C } & 3.1314563 & 0.4882850 & 1.4648284\end{array}$
$\begin{array}{llll}\text { P } & 0.5765012 & 0.6562275 & -0.9897683\end{array}$
$\begin{array}{llll}N & 0.3439506 & -0.4647314 & -2.2671298\end{array}$
$\begin{array}{llll}\text { C } & 0.8005727 & -0.1979795 & -3.5343551\end{array}$
$\begin{array}{llll}\text { N } & 1.4310321 & 0.9815179 & -3.7054986\end{array}$
$\begin{array}{llll}\text { C } & 1.8997617 & 1.2977287 & -4.9246917\end{array}$
$\begin{array}{llll}\text { C } & 1.7627576 & 0.4620613 & -6.0137437\end{array}$
$\begin{array}{llll}\text { C } & 1.1121900 & -0.7567132 & -5.8396084\end{array}$
C $\quad 0.6251985 \quad-1.0943674 \quad-4.5926789$
Rh $\quad 1.6305292 \quad 2.2625904 \quad-1.9924612$
$\begin{array}{llll}\text { C } & 1.7842580 & 3.3369511 & -0.5049541\end{array}$
$\begin{array}{llll}\text { O } & 1.8910482 & 4.0190342 & 0.4026394\end{array}$
Cl $\quad 2.7752424 \quad 3.9113464 \quad-3.2479555$
$\begin{array}{llll}\text { C } & -3.2739044 & 0.8963721 & 0.3543195\end{array}$
$\begin{array}{llll}\text { C } & -1.8460115 & 2.9536409 & 0.2053277\end{array}$
$\begin{array}{llll}\text { C } & 2.2697986 & -1.8498272 & 1.7554174\end{array}$
$\begin{array}{llll}\text { C } & 3.1929748 & -1.1198247 & -0.4596375\end{array}$
H $\quad-1.1787417 \quad-2.1801582 \quad 0.4151842$
H $\quad-0.1298769-1.3414037 \quad-2.1211401$
H $\quad-2.3577165 \quad-3.9842720 \quad 1.5071315$
H $\quad 0.1151621 \quad-2.0320387 \quad-4.4233069$
$\begin{array}{llll}\text { H } & -1.9973149 & -1.1839426 & 5.4989137\end{array}$
H $2.3919699 \quad 2.2585028 \quad-4.9820342$
H $\quad 2.1571313 \quad 0.7616694 \quad-6.9727318$
H $\quad 0.9861905 \quad-1.4378477 \quad-6.6703818$ 


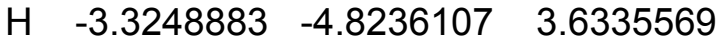
$\begin{array}{llll}H & 3.2552345 & -2.1786065 & 2.0834837\end{array}$
H $\quad 1.7022585-1.5540571 \quad 2.6388691$
H $\quad 1.7641978 \quad-2.6917746 \quad 1.2819217$
$\begin{array}{llll}H & -4.1696638 & 1.4981112 & 0.2044811\end{array}$
H $\quad-3.4604420 \quad-0.1045488-0.0358356$
$\begin{array}{llll}H & -3.0927790 & 0.8242674 & 1.4277087\end{array}$
$\begin{array}{llll}H & -3.1476669 & -3.3965794 & 5.6911427\end{array}$
$\begin{array}{llll}H & -2.7236213 & 3.5811081 & 0.0480667\end{array}$
H $\quad-1.6490962 \quad 2.9092563 \quad 1.2749791$
H $\quad-0.9992014 \quad 3.4254691 \quad-0.2898971$
$\begin{array}{llll}\text { H } & 4.1941887 & -1.4379609 & -0.1713578\end{array}$
H $\quad 2.6954285-1.9523816 \quad-0.9576311$
H $\quad 3.2925649 \quad-0.2977996 \quad-1.1699337$
$\begin{array}{llll}H & 4.1302420 & 0.1862847 & 1.7805251\end{array}$
H $\quad 3.2323307 \quad 1.3295351 \quad 0.7815222$
$\begin{array}{llll}H & 2.5817487 & 0.8136536 & 2.3461933\end{array}$
H $\quad-3.2329737 \quad 2.2424756 \quad-2.0493799$
H $\quad-1.5096731 \quad 2.0773763 \quad-2.3858519$
$\begin{array}{llll}H & -2.5323795 & 0.6344127 & -2.2784995\end{array}$

Optimised xyz coordinates and total energy [Hartree] of chloride complex $1 \cdot \mathrm{Cl}^{-}$.

55
Energy $=-2174.177079550$
C $\quad-2.5470782 \quad 1.0836748 \quad 1.7495506$
$\begin{array}{llll}N & -3.7562033 & 0.7061096 & 1.3061866\end{array}$
C $\quad-4.8272742 \quad 1.3375499 \quad 1.7877544$ 

$\begin{array}{llll}\text { C } & -4.7760087 & 2.3762981 & 2.7016909\end{array}$
C $\quad-3.5125664 \quad 2.7792893 \quad 3.1466747$
C $\quad-2.3884605 \quad 2.1371523 \quad 2.6802099$
$\begin{array}{llll}\text { N } & -1.4401002 & 0.4402632 & 1.2740772\end{array}$
$\begin{array}{llll}P & -1.3992305 & -0.9798633 & 0.3098887\end{array}$
N $\quad-0.6500905 \quad-0.4858039 \quad-1.1650176$
C $\quad-1.2727100 \quad-0.0592948 \quad-2.4114924$
$\begin{array}{llll}\text { C } & -0.2295939 & 0.7034121 & -3.2352265\end{array}$
N $\quad 0.2146977 \quad-1.4946269 \quad 0.6241718$
C $\quad 0.6956803 \quad-2.4025753 \quad 1.6650480$
$\begin{array}{llll}\text { C } & 0.3904739 & -3.8600336 & 1.2852564\end{array}$
P $\quad 0.9229264 \quad-1.1487440 \quad-0.9080836$
$\begin{array}{llll}N & 1.8968764 & 0.1981007 & -0.4781433\end{array}$
C $\quad 2.9931974 \quad 0.6690476 \quad-1.1428194$
C $\quad 3.7937646 \quad 1.6657486 \quad-0.5372395$
C $\quad 4.8938617 \quad 2.1322790 \quad-1.2197694$
C $\quad 5.1984436 \quad 1.6117611 \quad-2.4819213$
$\begin{array}{llll}\text { C } & 4.3513860 & 0.6424776 & -2.9918838\end{array}$
$\begin{array}{llll}\text { N } & 3.2708719 & 0.1808134 & -2.3616586\end{array}$
C $\quad 2.2058589 \quad-2.2018463 \quad 1.8271719$
C $\quad 0.0051533 \quad-2.0428184 \quad 2.9845647$
$\begin{array}{llll}\text { C } & -1.7828522 & -1.2730633 & -3.2051446\end{array}$
$\begin{array}{llll}\text { C } & -2.4410578 & 0.8726349 & -2.0727061\end{array}$
Cl $\quad 1.3335301 \quad 1.6613358 \quad 2.3197274$
H $1.6697307 \quad 0.6849926 \quad 0.4026915$
H $\quad-0.5349954 \quad 0.8429627 \quad 1.5628078$
H $4.5408962 \quad 0.2143735 \quad-3.9722242$
H $\quad 3.5154574 \quad 2.0315071 \quad 0.4424969$ 

H $\quad 6.0545338 \quad 1.9524586 \quad-3.0479354$
H $\quad-0.6621983 \quad 1.0339427 \quad-4.1816777$
H $\quad 0.1206808 \quad 1.5751322 \quad-2.6834341$
$\begin{array}{llll}H & 0.6397640 & 0.0809072 & -3.4523139\end{array}$
H $5.5191128 \quad 2.8974604 \quad-0.7755980$
H $\quad-5.7847666 \quad 0.9940249 \quad 1.4063043$
H $\quad-2.2522800 \quad-0.9660906 \quad-4.1430426$
H $\quad-0.9546637 \quad-1.9445906 \quad-3.4360100$
H $\quad-2.5161243 \quad-1.8249648 \quad-2.6153683$
H $\quad-1.3886331 \quad 2.4074802 \quad 2.9937488$
H $\quad-2.9359815 \quad 1.2076109 \quad-2.9865026$
H $\quad-3.1795196 \quad 0.3733704 \quad-1.4436017$
H $\quad-2.0804345 \quad 1.7438677 \quad-1.5268086$
H $\quad-3.4136956 \quad 3.5911275 \quad 3.8571719$
$\begin{array}{llll}H & -5.6817827 & 2.8566614 & 3.0453506\end{array}$
H $\quad 0.7442141 \quad-4.5516698 \quad 2.0536954$
H $\quad-0.6848335 \quad-4.0003265 \quad 1.1627035$
H $\quad 0.8768139-4.1135355 \quad 0.3417364$
H $2.5881840 \quad-2.8693057 \quad 2.6021135$
H $\quad 2.7335673 \quad-2.4253926 \quad 0.8979831$
H $\quad 2.4160103 \quad-1.1705293 \quad 2.1077968$
H $\quad 0.3522635 \quad-2.7072190 \quad 3.7785585$
H $\quad 0.2333300 \quad-1.0126555 \quad 3.2552319$
H $\quad-1.0781458 \quad-2.1508784 \quad 2.9032590$

Optimised xyz coordinates and total energy [Hartree] of chloride complex $4 \cdot \mathrm{Cl}^{-}$.

73

Energy $=-3217.613119374$ 

C $\quad 1.7039583 \quad 4.0047721 \quad 1.8051456$
C $\quad 0.6167516 \quad 3.1123329 \quad 1.7488342$
$\begin{array}{llll}N & -0.5706122 & 3.4020649 & 2.3334977\end{array}$
C $\quad-0.6874433 \quad 4.5814090 \quad 2.9745787$
C $\quad 0.3304070 \quad 5.5031089 \quad 3.0685461$
C $\quad 1.5558039 \quad 5.1999536 \quad 2.4672627$
N $\quad 0.7485146 \quad 1.9318991 \quad 1.0875823$
$\begin{array}{llll}\text { P } & -0.5375325 & 0.8598773 & 0.8335863\end{array}$
$\begin{array}{llll}\text { Mo } & -2.2973452 & 1.8670093 & 2.2728491\end{array}$
C $\quad-3.3221564 \quad 2.7997192 \quad 0.7762114$
O $\quad-4.0189817 \quad 3.3201873 \quad 0.0242662$
$\begin{array}{llll}N & -0.5335361 & 0.5435804 & -0.8423122\end{array}$
C $\quad-0.9457536 \quad 1.3777872 \quad-1.9842316$
C $\quad-0.7805011 \quad 2.8539712 \quad-1.6069791$
P $\quad 0.0298704 \quad-1.0577522 \quad-0.7778985$
$\begin{array}{llll}N & 0.1342523 & -0.6993615 & 0.8864027\end{array}$
C $\quad 0.6028360 \quad-1.5108763 \quad 2.0227470$
C $\quad-0.5897803 \quad-2.2251932 \quad 2.6639251$
Mo $\quad-0.8369866 \quad-3.0822520 \quad-1.9317111$
C $\quad-1.2423559 \quad-4.7412879 \quad-2.9604264$
O $\quad-1.4692244 \quad-5.7048917 \quad-3.5566072$
N $\quad 1.4213808 \quad-3.0757678 \quad-2.4234859$
C $2.0037952 \quad-4.0747960-3.1149690$
C $\quad 3.3343943 \quad-4.0845909 \quad-3.4670659$
$\begin{array}{llll}\text { C } & 4.1276045 & -2.9971678 & -3.0883275\end{array}$
C $3.5612000-1.9641835 \quad-2.3805234$
C $\quad 2.1931915 \quad-2.0252985 \quad-2.0541851$
N $\quad 1.6248579 \quad-1.0143453 \quad-1.3449712$ 

C $\quad-1.2825253 \quad-2.1289776 \quad-3.6774765$

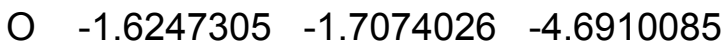
C $\quad-0.6779788 \quad-4.3479530 \quad-0.3399910$
$\begin{array}{llll}O & -0.6944301 & -5.1439235 & 0.4895025\end{array}$
C $\quad-2.7329265 \quad-2.8293039 \quad-1.4192849$
O
C $\quad-0.0114573 \quad 1.0988893 \quad-3.1660518$
C $\quad-2.4009873 \quad 1.0652038 \quad-2.3430248$
C $\quad 1.6395691 \quad-2.5203807 \quad 1.5188088$
C $\quad \begin{array}{lll}1.3055184 & -0.5946279 & 3.0294547\end{array}$
C $\quad-3.5940925 \quad 0.3801730 \quad 2.1014474$
$\begin{array}{llll}\text { O } & -4.3297869 & -0.5028258 & 2.0019084\end{array}$
C $\quad-3.5014070 \quad 2.9028434 \quad 3.4776134$
O $\quad-4.1938858 \quad 3.5111221 \quad 4.1746628$
C $\quad-1.6630034 \quad 0.9839654 \quad 3.9969789$
$\begin{array}{llll}\mathrm{O} & -1.4447178 & 0.5126836 & 5.0228316\end{array}$
H $\quad 1.6583186 \quad 1.7527879 \quad 0.6176815$
H $\quad 2.2490130 \quad-0.2393088 \quad-1.0443398$
H $\quad-1.6493382 \quad 4.7709773 \quad 3.4255759$
$\begin{array}{llll}H & 2.6252121 & 3.7184235 & 1.3167967\end{array}$
H $\quad 0.1695469 \quad 6.4309780 \quad 3.5971032$
H $\quad 1.6526705 \quad-1.1880735 \quad 3.8758342$
H $\quad 2.1609991 \quad-0.1082685 \quad 2.5626143$
H $\quad 0.6421386 \quad 0.1747573 \quad 3.4126618$
H $2.3818450 \quad 5.8971130 \quad 2.5180720$
H $\quad 1.3527709 \quad-4.8909790 \quad-3.3880207$
H $\quad-0.2704714 \quad-2.8212114 \quad 3.5199563$
H $\quad-1.3286686 \quad-1.5033525 \quad 3.0043020$ 

H $\quad-1.0713112 \quad-2.8842780 \quad 1.9450458$
H $\quad 4.1251523 \quad-1.1007156 \quad-2.0556408$
H $\quad 1.9575968 \quad-3.1487710 \quad 2.3508010$
H $\quad 1.2376656 \quad-3.1694397 \quad 0.7454546$
H $\quad 2.5099439 \quad-2.0029848 \quad 1.1188410$
$\begin{array}{llll}H & 5.1782638 & -2.9654988 & -3.3456361\end{array}$
H $\quad 3.7384170 \quad-4.9181709 \quad-4.0221121$
H $\quad-2.7270906 \quad 1.6615085 \quad-3.1964276$
H $\quad-2.5140258 \quad 0.0133172 \quad-2.5956132$
H $\quad-3.0557672 \quad 1.2802480 \quad-1.5013549$
H $\quad-1.1258698 \quad 3.4732432 \quad-2.4350134$
H $\quad-1.3608355 \quad 3.1197767 \quad-0.7274339$
H $\quad 0.2663687 \quad 3.0816426 \quad-1.4129920$
H $\quad-0.3131882 \quad 1.7118116 \quad-4.0160697$
H $\quad 1.0161579 \quad 1.3434825 \quad-2.8999024$
H $\quad-0.0461070 \quad 0.0590773 \quad-3.4771275$
Cl $\quad 3.4257000 \quad 1.3290427 \quad-0.3764936$

Optimised xyz coordinates and total energy [Hartree] of chloride complex $5 \cdot \mathrm{Cl}^{-}$.

63
Energy $=-3542.665547098$
C $\quad 0.5548863 \quad-1.1114536-4.4076887$
$\begin{array}{llll}\text { C } & 0.7820385 & -0.1625799 & -3.3976335\end{array}$
N $\quad 1.4225648 \quad 1.0029261 \quad-3.6542188$
C $\quad 1.8475720 \quad 1.2505438-4.9049376$
C $\quad 1.6587918 \quad 0.3645736 \quad-5.9436615$
C $\quad 0.9982036-0.8386992 \quad-5.6820272$
N $\quad 0.3671007 \quad-0.3784702 \quad-2.1228508$ 

$\begin{array}{llll}P & 0.6338204 & 0.7832576 & -0.9238692\end{array}$
Rh $1.6868498 \quad 2.3530645 \quad-2.0008392$
Cl $\quad 2.8333726 \quad 3.9505458 \quad-3.3671772$
$\begin{array}{llll}N & -0.8102388 & 0.9031699 & -0.0434237\end{array}$
C $\quad-2.0477465 \quad 1.6507534 \quad-0.3163585$
C $\quad-1.9059094 \quad 3.0821775 \quad 0.2099022$
$\begin{array}{llll}\text { P } & -0.3105092 & 0.0436512 & 1.3293522\end{array}$
$\begin{array}{llll}N & 1.1393157 & -0.0613288 & 0.4563955\end{array}$
C $\quad 2.4617123 \quad-0.5785657 \quad 0.8420279$
C $3.1861966-1.0402609-0.4242789$
Rh $\quad-0.5842540 \quad 0.5737205 \quad 3.4214085$
Cl $\quad-0.9885167 \quad 0.9617679 \quad 5.7495953$
$\begin{array}{llll}N & -1.5558325 & -1.3435384 & 3.4852621\end{array}$
C $\quad-2.1063458-1.8727565 \quad 4.5912033$
C $\quad-2.7235732 \quad-3.1050340 \quad 4.5979385$
C $\quad-2.7774028 \quad-3.8304072 \quad 3.4047189$
C $\quad-2.2192449 \quad-3.3061532 \quad 2.2608234$
C $\quad-1.6057839-2.0446196 \quad 2.3273895$
N $\quad-1.0392068 \quad-1.4787283 \quad 1.2307490$
C $\quad 0.2609977 \quad 2.1912408 \quad 3.2596259$
O $\quad 0.7883517 \quad 3.2020816 \quad 3.1603470$
C $\quad-2.2833240 \quad 1.6578739 \quad-1.8286662$
C $\quad-3.2066363 \quad 0.9368240 \quad 0.3832976$
C $3.2595024 \quad 0.5259136 \quad 1.5414122$
C $2.2575389-1.7675806 \quad 1.7833487$
C $\quad 1.8568926 \quad 3.4307152 \quad-0.5289235$
O $\quad 1.9637408 \quad 4.1051038 \quad 0.3896056$
H $\quad-1.0781068 \quad-2.0038293 \quad 0.3334518$ 

H $\quad-0.1338431 \quad-1.2662161 \quad-1.9149675$
H $\quad-2.2328314 \quad-3.8227408 \quad 1.3115015$
H $\quad 0.0379270 \quad-2.0248941 \quad-4.1496077$
H $\quad-2.0256983 \quad-1.2542009 \quad 5.4741269$
$\begin{array}{llll}H & 2.3491279 & 2.1999800 & -5.0296972\end{array}$
$\begin{array}{llll}H & 2.0193665 & 0.6105829 & -6.9314172\end{array}$
H $\quad 0.8324265 \quad-1.5573399 \quad-6.4743878$
$\begin{array}{llll}H & -3.2550617 & -4.8013196 & 3.3736637\end{array}$
H $\quad 3.2267772 \quad-2.1697621 \quad 2.0791319$
H $\quad 1.7270582 \quad-1.4625830 \quad 2.6867481$
H $\quad 1.6851617 \quad-2.5530063 \quad 1.2912430$
H $\quad-4.1357500 \quad 1.4739953 \quad 0.1907878$
H $\quad-3.3070454 \quad-0.0837274 \quad 0.0156648$
$\begin{array}{llll}H & -3.0508296 & 0.9059527 & 1.4628839\end{array}$
H $\quad-3.1508749 \quad-3.4863766 \quad 5.5134682$
$\begin{array}{llll}H & -2.8150490 & 3.6542427 & 0.0167308\end{array}$
H $\quad-1.7260025 \quad 3.0754912 \quad 1.2843446$
H $\quad-1.0724610 \quad 3.5855092 \quad-0.2788318$
H $\quad 4.1686169 \quad-1.4324000 \quad-0.1602586$
H $\quad 2.6185668 \quad-1.8215440 \quad-0.9281990$
H $\quad 3.3279652 \quad-0.2094722 \quad-1.1173492$
H $\quad 4.2450363 \quad 0.1603482 \quad 1.8346643$
H $\quad 3.3932741 \quad 1.3775662 \quad 0.8755913$
H $2.7378962 \quad 0.8628625 \quad 2.4364089$
H $\quad-3.1991459 \quad 2.2055975 \quad-2.0527564$
H $\quad-1.4593863 \quad 2.1483892 \quad-2.3495081$
H $\quad-2.3794952 \quad 0.6408809 \quad-2.2071792$
Cl $\quad-1.1425438 \quad-3.0017147 \quad-1.4641006$ 